\title{
“AND I THINK TO MYSELF - WHAT A MARVEL-OUS WORLD" AN EXAMINATION OF MARVEL STUDIOS' INFLUENCE AND ROLE IN THE FRANCHISING OF CONTEMPORARY SUPERHERO FILMS
}

\author{
By \\ Elizabeth C.A. MacLeod, B.A. (Hons.) \\ A thesis submitted to the Faculty of Graduate Studies and Research \\ In partial fulfillment of the requirements for the degree of \\ Masters of Arts in Film Studies
}

Carleton University

Ottawa, Ontario

April 2015 


\section{TABLES OF CONTENTS}

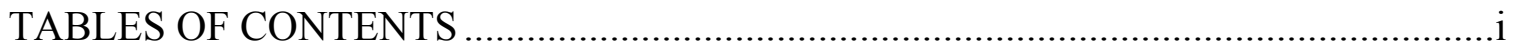

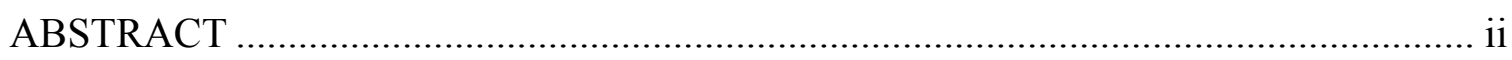

ACKNOWLEDGEMENTS............................................................................... ii

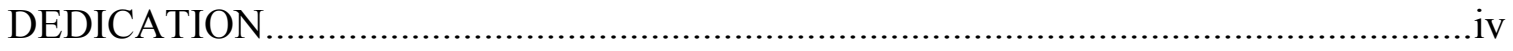

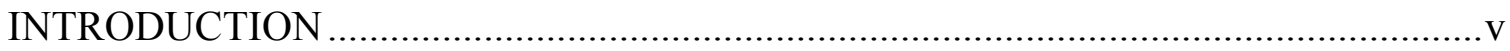

CHAPTER ONE - ORIGIN STORY: SUPERHERO BUSINESS AND CINEMATIC

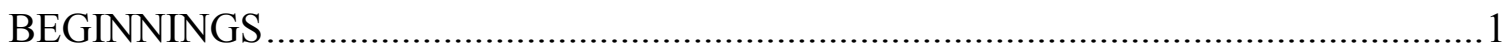

CHAPTER TWO - “SOME ASSEMBLY REQUIRED”: MARVEL STUDIO'S

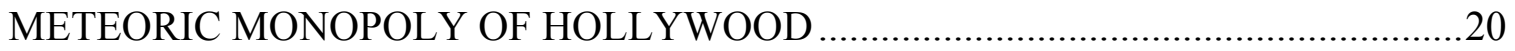

CHAPTER THREE - “A FINGER IN EVERY PIE”: CONVERGENCE CULTURE AND THE TRANSMEDIA NARRATIVE OF THE "MARVEL CINEMATIC UNIVERSE."

CHAPTER FOUR - “GREEN WITH ENVY (AND CASH)”: THE FUTURE OF SUPERHERO FRANCHISING IN HOLLYWOOD.

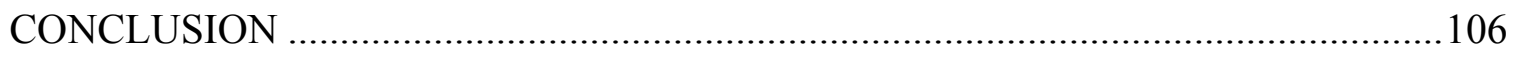

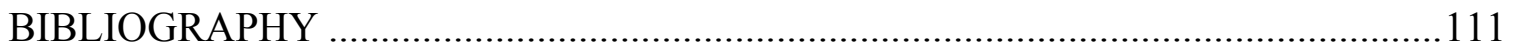

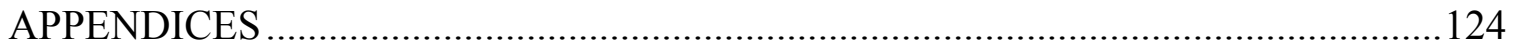




\begin{abstract}
This thesis presents a framework for understanding Marvel Studios' current domination of superhero franchising in Hollywood and the impact of this domination on the film industry as a whole. Since the turn of the millennium, superhero films have developed into one of the most reliable, and profitable, properties studios can offer in the face of shrinking film attendance. Marvel Studios has established itself as the leading producer of superhero films, culminating in the success of the Avengers (2012) as reportedly the third-highest grossing film domestically and worldwide in the history of the film industry. In a post-Avengers film industry, Marvel Studios, I argue, has created a new standard for the franchising of superhero films, through its strategic exploitation of what Henry Jenkins has referred to as "convergence culture." In the first chapter of the thesis, the success of Marvel Studios is analyzed in the context of the company's history in comic book production and marketing in the 1940s, its first attempts at film adaptation in the 1960s, and its bankruptcy in the 1990s. Chapter Two covers the establishment of the current era of Marvel Studios and the success of its franchises, like Iron Man (2008) and the Avengers (2012). In Chapter Three, I analyze how contemporary practices of transmedia and convergence culture have been crucial to the development of Marvel Studios" "Marvel Cinematic Universe." My fourth and final chapter examines the future plans of Marvel Studios' and those of other studios who own rights to superhero characters. The aim overall is to illuminate the ground breaking impact on the contemporary film industry, both creative and monetary, of Marvel Studios and its novel approach to media franchising.
\end{abstract}




\section{ACKNOWLEDGEMENTS}

Firstly, I would like to thank my supervisor, Dr. Charles O’Brien, whose guidance, knowledge and support enabled me to create a thesis on a subject that I truly love. Writing this thesis was never truly "work." I also extend my thanks and gratitude to my panel members Dr. Malini Guha, Dr. Marc Furstenau, and Dr. Brian Johnson.

I would also like to thank Diane Berezowski and Rose Greider, who are two sides of the same coin of kindness and compassion, and who always brought a smile to my face during stressful and tense times.

I want to thank Michelle MacDonald, née Everist for encouraging me to attend Carleton University. Without her encouragement, I would never have seriously considered studying for my Masters in Ottawa; thank you big sister.

Lastly, I thank my parents Donald Alexander MacLeod and Mary Alice Ryan. I would be nowhere and nothing without their unending and immovable belief in me. 


\section{DEDICATION}

In dedication to M. Eileen Ryan, B.A., M.P.A., LL. B., my Aunt, Godmother, and fellow Carleton University Graduate 


\section{INTRODUCTION}

Superhero comics have often been viewed as "lowbrow" entertainment. Due to their widespread availability, popularity, and low prices, along with their soap-operatic plots and larger-than-life characters, superhero comics have had a somewhat negative stigma associated with them. The grandiosity and fantastical powers of superheroes make it difficult to appreciate the unique enjoyment offered by superhero films, despite the superhero genre's influence on the film industry and popular culture at large, and the genre's enormous financial success at a time of crisis in the film industry. These derisive, and at times elitist, prejudices can prevent individuals from enjoying superhero films, and appreciating the unique construction and artistry that goes into their making. Ultimately, the joke is on those who scoff at superheroes, as superhero films have become one of the most reliable and profitable franchises for Hollywood studios and the film industry at large, providing pleasure and entertainment to enormous global and domestic audiences who gladly pay to see pop culture's equivalent of mythical gods on the big screen.

Seriality, multiple creators, long-term continuity, a character backlog, contemporary ties to a deep history, and a sense of permanence are elements that characterize comic book universes. ${ }^{1}$ Many of pop culture's earliest franchises drew on comics-derived material. For example, within a few years of his creation in 1938, Superman was appearing in comic books, comic strips, live action serials, animated cartoons, and radio dramas. ${ }^{2}$ Each of these media platforms contributed to this iconic

\footnotetext{
${ }^{1}$ Sam Ford and Henry Jenkins, "Managing Multiplicity in Superhero Comics: An Interview with Henry Jenkins," in Third Person: Authoring and Exploring Vast Narratives, eds. Pat Harrington and Noah Wardrip-Fruin. (Cambridge: MIT Press, 2009), 304.

2 Ibid., 304.
} 
character's evolution, as did various Superman television productions a few decades later in the 1950s and film in the 1980s. ${ }^{3}$ Superhero comics, a transmedia phenomenon from the start, anticipated the expansive and immersive world building essential to what has been called convergence culture. ${ }^{4}$

The works of media scholar Henry Jenkins are crucial in comprehending developments in convergence culture and transmedia storytelling that have become prominent over that past two decades. The main development concerns the integration of multiple texts to create a narrative so large, encompassing and constantly growing, that it cannot be contained within a single medium. ${ }^{5}$ In convergence culture, each platform in a transmedia franchise allows for the introduction of new parts into the larger narrative. ${ }^{6}$ A narrative's world can be expanded and explored across multiple entertainment platforms with any given product providing a point of entry into the franchise as a whole. ${ }^{7}$ The Wachowskis' Matrix franchise exemplifies the degree to which a transmedia franchise, a narrative or property can exist across multiple platforms and formats. ${ }^{8}$ The possibilities are endless as to how an audience can consume a transmedia narrative, which imposes special challenges on those who wish to analyze such narratives.

Superhero comics provide the perfect medium for convergence culture and transmedia franchising. Indeed, today's convergence culture can be traced back to the comics industry in the 1930s and 1940s. Since their inception, DC Comics and Marvel Comics have treated all of their titles as interconnected; characters move across different

\footnotetext{
${ }^{3}$ Ibid., 304.

${ }^{4}$ Ibid., 305.

${ }^{5}$ Henry Jenkins, "Searching for the Origami Unicorn: The Matrix and Transmedia Storytelling," in Convergence Culture: Where Old and New Media Collide. (New York: New York University Press, 2006), 95.

${ }^{6}$ Ibid., 95.

${ }^{7}$ Ibid., 96.

${ }^{8}$ Ibid., 95.
} 
series and universe-wide events periodically require readers to buy titles that they were not otherwise reading to fully understand their full ramifications. ${ }^{9}$ Each book approaches the same characters from a different perspective, to thus round out the story in new ways. Each book must satisfy the hardcore fan's mastery over a complex mythology while trying to remain accessible to first-time readers. ${ }^{10}$ One could also debate whether superhero comics represent multiple coherent and self-contained genres, or represent character types that play across a range of genres. ${ }^{11}$ The superhero genre itself took definition slowly, building off a range of related genre traditions, i.e., the detective story (Batman), the science fiction saga (Fantastic Four), the spy genre (Iron Man, Black Widow), the soap opera (Spider-Man), horror (the Hulk), the supernatural (Doctor Strange) and so forth. ${ }^{12}$ These different flavors of the superhero genre offer specific possibilities for superhero franchises. ${ }^{13}$ From one genre can emerge another, just as a secondary character in one franchise can become the lead in another franchise. ${ }^{14}$ For example, the superhero Black Panther, fellow Avenger and sovereign of his country, introduces African American and geopolitical issues in his own solo series, creating comic storylines that can be merged into other genres. ${ }^{15}$ This mixed genre strategy allows these franchises to refresh themselves on a regular basis, while expanding their demographics. ${ }^{16}$ In the following chapters, I examine how Marvel Studios has changed the standard of the franchising of superhero films, and how it has become the most successful and dominant studio regarding superhero films through the creation of its

\footnotetext{
${ }^{9}$ Ford and Jenkins, "Introduction," 305.

${ }^{10}$ Ibid., 305.

${ }^{11}$ Ibid., 310.

12 Ibid., 310.

${ }^{13}$ Ibid., 310.

${ }^{14}$ Ibid., 310 .

${ }^{15}$ Ibid., 310.

${ }^{16}$ Ibid., 310.
} 
"Marvel Cinematic Universe," [hereafter referred to as the "MCU"] which involved the skillful exploitation of certain aspects of convergence culture.

In the First Chapter, I establish context and background for the success of Marvel Studios and its "MCU" by researching the origins of Marvel Comics, and the works of Stan Lee and Jack Kirby. The beginnings of Marvel Studios and the sale of Marvel Comics' most iconic characters to the Hollywood studios, consisting of $20^{\text {th }}$ Century Fox Pictures, Sony Pictures and Universal Studios, is documented to establish the distribution of Marvel's superhero characters. I also investigate the Marvel films unaffiliated with the "MCU" to shed light on how Hollywood produced superhero films prior to the production of Marvel Studios' superhero films.

In the Second Chapter, the development and growth of "Phase One" of the "MCU" is scrutinized. Here the focus is on the growing influence and power of Marvel Studios under the leadership of Kevin Feige, Marvel Studio's President of Production, and Joss Whedon, the "MCU's" creative showrunner. I also investigate the various components that influence the decisions made at Marvel Studios, such as considerations pertaining to the hiring of directors, actors, and other creative personnel. This chapter touches upon key films and franchises of the "MCU," with an emphasis on the enormous success of the Avengers (2012), and its impact on the film industry. Also included is an assessment of rumors regarding decisions and plans for future films in the "MCU."

The Third Chapter scrutinizes how superhero films function within convergence culture and transmedia franchising. The origins of transmedia storytelling are explored, with an emphasis placed on film scholar Marsha Kinder's observations regarding "transmedia intertextuality," and its historical influence on popular culture, leading to the 
development of convergence culture. The Matrix (1999) is utilized as an example of convergence culture, and how the film industry can benefit from the application of convergence culture in the film industry, through franchises and synergy. Henry Jenkins' writings on convergence culture are used to examine the "MCU" in connection with convergence culture's increasing importance to the development of contemporary film franchises. Each transmedia element of the "MCU" (television, comics etc.) is identified, and their individual importance to the construction of the larger narrative is addressed.

The fourth and final chapter examines the future of superhero franchising in Hollywood, and how the "MCU" has changed how superhero franchises are developed by examining how Sony, $20^{\text {th }}$ Century Fox, and Warner Bros., the major Hollywood studios who retain the rights to the most important superhero characters, attempt to develop their own superhero films and create their own "cinematic universes" in a postAvengers world. Here I provide further context regarding the current state of the film industry, and why the studios rely so heavily upon franchises and blockbuster films. The chapter presents my research on how The Avengers changed the development of superhero franchises, and how the success of the "MCU" has established Marvel Studios as a quality brand to the public, on par with the Walt Disney Company's brand reputation in providing quality entertainment. I also delve into the intricate ownership of Marvel's superhero characters amongst Marvel Studios, $20^{\text {th }}$ Century Fox and Sony. In addition, the superhero franchise plans of $20^{\text {th }}$ Century Fox, who still retain the rights to the $X$-Men and Fantastic Four Marvel superheroes, and Sony, who as of 2015 now shares the rights of Spider-Man with Marvel Studios, are scrutinized and examined. 


\section{CHAPTER ONE}

\section{ORIGIN STORY: SUPERHERO BUSINESS AND CINEMATIC BEGINNINGS}

This chapter will examine the origins of the publisher, Marvel Comics and provide a brief history of the Marvel films made prior to the creation in 2007 of Marvel Studios. ${ }^{17}$ Examining the early history of Marvel Comics, and its iconic characters creates a greater understanding of the project of Marvel Studios and how it, along with DC Comics, became one of the two most powerful comics publishers in the comic book industry. In turn, analyzing the Marvel films non-affiliated with Marvel Studios (Blade, X-Men, Spider-Man et. al) will provide context for the impetus of Marvel establishing its own studio in-house to make its own films based on its properties. The examination of Marvel's business and cinematic past, both distant and recent, will shed light on Marvel Studio's present success.

\section{"Marvel's Origins in Pulp Magazine Publishing"}

Marvel Comics was created by American pulp magazine publisher Martin

Goodman. Born in Brooklyn, New York in 1908 to Russian immigrants, Goodman copyrighted his new company under the name of Timely Comics in $1939 .{ }^{18}$ The growing popularity of the comic book medium, and the nascent trend of superheroes - in particular the runaway success of Jerry Siegel and Joe Shuster's Superman, published by Detective Comics (later known as DC Comics) in June 1938, premiering on the cover

\footnotetext{
${ }^{17}$ Devin Leonard, “The Pow! Bang! Bam! Plan to Save Marvel, Starring B-List Heroes,” Bloomberg Businessweek, April 2, 2013, accessed April 20, 2014, http:/www.businessweek.com/printer/articles/192489-kevin-feige-marvelssuperhero-at-running-movie-franchises, 8.

${ }^{18}$ Sean Howe, Marvel Comics: The Untold Story (New York: Harper Perennial, 2012), 9.
} 
feature of Action Comics \#1 - propelled Goodman to contract with the newly formed comic book packager, Funnies, Inc. ${ }^{19}$ Funnies, Inc., and sales agent Frank Torpey, made a deal for Goodman to publish strips for a new comic book anthology: Marvel Comics \#1, which featured the first appearances of two characters who would become associated with the Marvel brand: the android Human Torch and Namor, the Sub-Mariner. ${ }^{20}$ The issue sold 80,000 copies on its first printing in September 1939, and a massive 800,000 copies on its second printing, which was better than the sale of an average DC Comics title for the time. ${ }^{21}$ From then on a cohesive "Marvel" universe began to coalesce. A key development was the release of Marvel Mystery Comics \#7-Marvel Comics' new title instituted by Goodman with its second issue - which hinted that the characters Namor and the Human Torch existed within the same fictional universe. ${ }^{22}$ In 1940, Marvel Mystery Comics \#8 and \#9 featured as its headline character Namor, who was shown attacking renowned monuments from the Empire State Building to the Bronx Zoo, thus establishing the cohesion of Marvel Comics as a fictional universe with a grounding in the "real world.",23 Further successful productions from Marvel Comics soon followed, such as Captain America. Created by Jack Kirby, born Jacob Kurtzberg, and Joe Simon, Captain America followed the lead of earlier Marvel Comics heroes existing in the "real world" by combatting the real-life villains of World War II; on December 20, 1940 Captain America \#1 - featuring Captain America punching Adolf Hitler - hit the newsstands and sold nearly a million copies, exceeding everyone's expectations. ${ }^{24}$ It was also during this period, before Captain America \#1 went to press, when Stan Lee, born

\footnotetext{
${ }^{19}$ Howe, Untold Story, 14.

${ }^{20}$ Ibid., 14.

${ }^{21}$ Ibid., 14.

22 Ibid., 15.

${ }^{23}$ Ibid., 16.

${ }^{24}$ Ibid., 18, 20.
} 
Stanley Lieber - aspiring writer and cousin to Martin Goodman's wife Jean Goodman was hired at Timely Comics as an assistant, and soon began writing comics stories for Timely Comics' characters, including Captain America. ${ }^{25}$ Captain America's runaway popularity marked the beginning of Marvel Comics' (nee Timely) success, but after World War II the comics publisher had to adapt its creative strategies and create new, more relevant characters for their fans to enjoy.

Following the aftermath of World War II, Marvel Comics returned to the creative drawing board for new stories and characters. Throughout the war, Captain America had been Marvel's best-selling title in a field that was rapidly growing. In less than two years, the number of comic books sold each month grew from 15 million to 25 million, and by 1943 it was a $\$ 30$ million (the equivalent of roughly $\$ 412$ million today, adjusted for inflation) per year industry. ${ }^{26}$ However, comic book trends changed quickly. Superheroes waned in popularity, as they now lacked Axis enemies and a dedicated readership of U.S. servicemen. ${ }^{27}$ A large percentage of the comics' industry sales were to overseas GIs, and Captain America couldn't have had a better audience; with stories like "Trapped in the Nazi Stronghold" and "Blitzkrieg to Berlin," the average print run of a Marvel comic book during the war approached a half million per issue. ${ }^{28}$ Another factor influencing the comics industry was panic in Postwar America over the "influence" comic books had on juvenile delinquency, with provincial towns organizing comic bonfires, respected publishers, such as the Times, printing scathing articles denouncing comics, and some towns and cities, including Detroit, introducing legislation to ban the

\footnotetext{
${ }^{25}$ Ibid., 21.

${ }^{26}$ Referring to the sale of comic books see "US Inflation Calculator," and Sean Howe's Marvel Comics: The Untold Story, 25.

${ }^{27}$ Ibid., 25.

${ }^{28}$ Ibid., 27.
} 
supposed comic-book "scourge. ${ }^{, 29}$ Comics publishers took preemptive action and devised a series of content guidelines, with crime and horror comics supplanted by western, comedic, and romantic comics. ${ }^{30}$ Unfortunately, the anti-comic furor reached a boiling point in April 1954 when the well-known and respected child psychologist Frederic Wertham - a prominent critic of comics for years - published selections from his book Seduction of the Innocent, a full-blown attack on the lurid contents of crime, horror and superhero comics. ${ }^{31}$ A U.S. Senate sub-committee on juvenile delinquency followed, expressing the same views towards comics, using Wertham as an expert witness. ${ }^{32}$ Fifteen comic publishers closed down in the summer of 1954, and the remaining publishers formed the Comics Magazine Association of America that instituted self-regulating rules modeled after Hollywood's Hays Code; if a comic book didn't have a Comics Code seal, the distributors wouldn't stock it. ${ }^{33}$ Comic books were losing their momentum; then at Marvel Comics a new savior arrived: The Fantastic Four.

The impetus for The Fantastic Four, which would lead to the development of a larger, connected "Marvel Universe," came from the time-old tradition of copying the competition. In 1961 after a game of golf between Martin Goodman and Jack Liebowitz, the publisher of rival DC Comics, Goodman went to Stan Lee with an order to copy DC Comics' idea of The Justice League of America, where DC Comics put its most popular characters such as Superman, Batman, and Wonder Woman, into a single superhero group, and found themselves with a surprise success. ${ }^{34}$ Lee's result was The Fantastic Four \#1, published on August 8, 1961, and was nothing like the other superhero titles for

\footnotetext{
${ }^{29}$ Ibid., 27.

${ }^{30}$ Ibid., 27

${ }^{31}$ Ibid., $29-30$

${ }^{32}$ Ibid., 30

${ }^{33}$ Ibid., 31.

${ }^{34}$ Ibid., 2.
} 
sale. ${ }^{35}$ The Fantastic Four were the principle characters, lacking colorful costumes while having distinct and complicated personalities, which led them to bicker with each other. Lee and Kirby emphasized the internal struggles of the dysfunctional team, offset by sleek gadgets and impressive headquarters, and how they were ultimately a family to one another. ${ }^{36}$ The Fantastic Four saved Marvel Comics at a time when, in the words of Jack Kirby, "[Marvel] was on its ass, literally...when I came around, they were practically hauling out the furniture," and the key to their success was creating relatable, but complicated, human characters who had struggles and triumphs like ordinary people. ${ }^{37}$

Stan Lee and Steve Ditko soon introduced the iconic everyman superhero Spider-Man on June 1962 in Amazing Fantasy \#15, who behind his superhero identity was the ordinary Peter Parker, an outcast nerd who struggled to make the right choices. ${ }^{38}$ Spider-Man's character development as the angst-ridden outsider was radically different from the traditional superhero character, and struck a chord with readers; so much so that the superhero got its own title, The Amazing Spider-Man by the end of the year. ${ }^{39}$ Marvel further developed the idea of the "outsider" superhero with the creation of the $X$-Men (first issue sold on September 10, 1963), who were composed of heroic super-powered teenage mutants, who used their abnormal abilities to fight against destructive mutants, while being viewed with suspicion by the very society they fought to protect. ${ }^{40}$ That same month Marvel also introduced another superhero team, The Avengers, consisting of an all-star team of Marvel marquee names (Iron Man, Ant-Man, the Wasp, Thor, the

\footnotetext{
${ }^{35}$ Ibid., 38.

${ }^{36}$ Ibid., 39.

${ }^{37}$ Ibid., 2.

${ }^{38}$ Ibid., 2, 41.

${ }^{39}$ Ibid., 42.

${ }^{40}$ Ibid., 47-48.
} 
Hulk, later joined by Captain America in The Avengers \#4) joining forces to defeat crime. $^{41}$

This star-studded superhero lineup marked a new era for Marvel Comics, opening a new phase in how their characters interacted with each other within their own "Marvel Universe." Although there had been earlier examples of Marvel's heroes interacting with one another, for example when Spider-Man attempted to join the Fantastic Four in Amazing Spider-Man \#1 and the Hulk appearing in The Fantastic Four \#12, the team-up of Marvel's popular heroes in The Avengers is the definitive example of how Marvel's creations built the groundwork for a self-contained fictional construct called "The Marvel Universe," in which all of the publisher's heroes' adventures were intertwined with great complexity. ${ }^{42}$ Not only did this shared universe come with the benefit of unlimited crosspromotion of Marvel's titles, but more importantly, it had narrative effects that would become the Marvel Comics touchstone: the impression that these characters shared a world, that the actions of each character had repercussions on the others, with each comic being a thread in one mega Marvel story. ${ }^{43}$ Inside its "Marvel Universe," The Fantastic Four's nemesis Doctor Doom battled Spider-Man, the Human Torch spoke at Peter Parker's high school assembly, and the Marvel heroes populated every corner of the world, with the Fantastic Four, Spider-Man, Daredevil, and the Avengers based in New York City, the X-Men making their home in Westchester county, with Marvel's heroes' adventures taking them all around the world. ${ }^{44}$

\footnotetext{
${ }^{41}$ Ibid., 47.

42 Ibid., 3, 47.

${ }^{43}$ Ibid., 47.

${ }^{44}$ Ibid., 47, 70.
} 
"Superheroes in Hollywood"

As Marvel's empire and stable of characters grew, its popularity (and profits) piqued the interest of Hollywood. In 1968, Martin Goodman sold the company to Perfect Film \& Chemical Corp., which changed its name to Cadence Industries. ${ }^{45}$ In the late 1970s, Cadence sent Stan Lee to Los Angeles, but the major studios weren't interested in costumed heroes who weren't Superman. ${ }^{46}$ Although it seems laughable now that Hollywood would have nothing to do with Marvel's superheroes, it was an era long before computer graphics lowered the cost of making a Spider-Man movie with special effects that weren't laughable and crude. ${ }^{47}$ It was in 1986 that Marvel Comics' parent company, the Marvel Entertainment Group (MEG; now known as Marvel Entertainment), began licensing the characters from its expansive library to various studios. ${ }^{48}$ One might think Marvel Entertainment would select one of their most popular characters to make into their first feature film, such as Spider-Man, The Hulk, or the X-Man Wolverine, but the first Marvel character to be theatrically brought to life was the ill-tempered cult classic Howard the Duck. ${ }^{49}$ Howard the Duck was created by Steve Gerber, with its first issue in 1976 after appearing in earlier Marvel comics, and chronicled the existentialist, social satirical, and at times meta-fictional, misadventures of the anthropomorphic duck in human society. ${ }^{50}$ However, Howard the Duck was ultimately a one-hit wonder, whose popularity dropped off remarkably after its first several issues. ${ }^{51}$ Despite George Lucas

\footnotetext{
45 Devin Leonard, “The Pow! Bang! Bam! Plan to Save Marvel, Starring B-List Heroes,” Bloomberg Businessweek, April 2, 2013, accessed April 20, 2014, http://www.businessweek.com/printer/articles/192489-kevin-feige-marvelssuperhero-at-running-movie-franchises, 2 .

${ }^{46}$ Ibid., 2 .

${ }^{47}$ Ibid., 2.

${ }^{48}$ Diane Panosian, "Behind The Money of Marvel's Mighty Movies," Studio System News, May 2, 2013, accessed February 20, 2014, http://www.studiosystemnews.com/behind-the-money-of-marvels-mighty-movies/, 1.

${ }^{49}$ Panosian, "Money Marvel," 1.

${ }^{50}$ Howe, Untold Story, 134, 178-179.

${ }^{51}$ Ibid., 205.
} 
- creator of the classic pop culture properties Star Wars and Indiana Jones - producing Howard the Duck the character's cult classic appeal made the Marvel Entertainment's decision to produce its first feature length film around such a niche character rather illogical. ${ }^{52}$ The result was that the film was a colossal failure. The film cost $\$ 37$ million, (roughly the equivalent to an $\$ 80$ million budget today), with an additional $\$ 8$ million on P\&A (\$17 million adjusted for inflation), but only grossed \$37 million worldwide when it opened on August 1, 1986, and was considered an enormous box office disappointment, bringing Marvel's ambitions to a halt [See Appendix B]. ${ }^{53}$ The film strayed from the comic in terms of the character's personality and the books' satirical approach, and has infamously gone down as an insult to the comic book character. ${ }^{54}$ Howard the Duck was nominated that year for seven Razzies (the Raspberry Awards are the Oscar equivalent for bad films), and won four of its categories. ${ }^{55}$ It was also rumored a fistfight broke out between the heads of production at Universal Studios, Marvel's studio collaborator in making the film, over the Howard the Duck's critical and financial failure. ${ }^{56}$ Howard the Duck did not provide Marvel with the springboard into film, and Hollywood, it had hoped for.

Marvel's reputation in film, mishandled by its owner Cadence Industries, continued to slide through the 1970s and early 80s. Cadence's cavalier distribution of Marvel's character rights to second-tier studios, such as Cannon Films, whose lowbudget films of The Punisher (1989) and Captain America (1990) were commercial

\footnotetext{
${ }^{52}$ Panosian, "Money Marvel," 1.

${ }^{53}$ Referring to the cost of Howard the Duck see "US Inflation Calculator," and Sean Howe Marvel Comics: The Untold Story, 292.

${ }^{54}$ Referring to the failure of Howard the Duck see Chris Dillard "History of Marvel Studios," 6 and Diane Panosian

"Behind The Money of Marvel's Mighty Movies," 2.

${ }^{55}$ Dillard "History," 6.

${ }^{56}$ Ibid., 6.
} 
failures. ${ }^{57}$ In 1993, producer Roger Corman raised the funds for a two million dollar budgeted Fantastic Four film and was completed in 1994, but the film ultimately went

unreleased. ${ }^{58}$ Marvel's future, and now former, CEO/chairman Avi Arad, bought the title and destroyed every print, with only one copy surviving, which can now be found on YouTube. $^{59}$

However, in the 1980s, the situation began to change when multiple Hollywood studios purchased the rights to various Marvel characters. The year of 1986 was a watershed moment for the comics industry; comics were gaining more respect from the rest of the world, and Marvel got its first real foothold in Hollywood. ${ }^{60}$ There was little improvement to Marvel's business and finances when financier Ron Perelman took control of Marvel in 1989, solely planning to use it as the cornerstone of his own media empire. ${ }^{61}$

"Bankruptcy and Merger in the 1990s"

As a result of the quality of Marvel's comics, their central creative medium, plummeting, the fans rebelled by closing their wallets, and Marvel Comics filed for Chapter 11 bankruptcy in late $1996 .^{62}$ Marvel's bankruptcy is what led to the parceling and selling of its characters to Hollywood's studios. Beginning in 1991, Marvel licensed several series to $20^{\text {th }}$ Century Fox Pictures; the most popular being the animated X-Men (1992-1997) and Spider-Man (1994-1998) series. ${ }^{63}$ The Marvel superhero group known

\footnotetext{
${ }^{57}$ Leonard, "Pow!," 2.

${ }^{58}$ Panosian, "Money Marvel," 2.

${ }^{59}$ Ibid., 6.

${ }^{60}$ Howe, Untold Story, 292.

${ }^{61}$ Leonard, "Pow!," 2.

${ }^{62}$ Ibid., 3.

${ }^{63}$ Dillard "History," 7.
} 
as Power Pack was intended to become a TV show, but never got past the filmed pilot; however, Fox did show reruns of Power Pack's pilot over the years, especially on Saturday mornings to coincide with Spider-Man and X-Men cartoons. ${ }^{64}$ Due to the $X$ Men's growing popularity, Fox attempted a live-action film of Generation $X$ in 1996, a spin-off of the animated $X$-Men, but the most infamous Fox production was Nick Fury: Agent of SHIELD (1998), which cast actor David Hasselhoff as the titular Fury. ${ }^{65}$

While Marvel's plans for films based on its characters stalled, and remained stuck in the realm of made-for television movies, DC Comics' Superman and Batman franchises dominated the box office in the 1980s and early 90s. ${ }^{66}$ Warner Bros. Studios attained the rights to the entire DC Comics library during the time period when Steve Ross and his Kinney Corporation purchased the company in November 1969, which became Warner Communications, Inc. ${ }^{67}$ Ross had also purchased DC Comics, and its classic characters, which were folded into Warner Communications, Inc, making Warner Bros. Studios the sole proprietor of DC Comics' entire library. ${ }^{68}$ The purchase paid off immensely with the critical and box office successes of Superman (1978), Batman (1989), and Batman Returns (1992). Marvel existed in a realm of middling embarrassment, until its merger with company ToyBiz revitalized its ambitions.

Marvel's merger with ToyBiz in 1998 gave the company an opportunity to rebuild and regroup, and successfully broke the cinematic glass ceiling associated with comicbook superheroes, proving once and for all that superheroes were viable business

\footnotetext{
${ }^{64}$ Ibid., 7.

${ }^{65}$ Ibid., 7.

${ }^{66}$ Panosian, "Money Marvel," 2.

67 "Warner Bros. Company History," Warner Bros. Entertainment Inc., 2014, accessed October 15, 2014, http://www.warnerbros.com/studio/about/company-history.

68 "Warner Bros. Company History, 1."
} 
opportunities. ${ }^{69}$ The mastermind of Marvel's rebirth was ToyBiz CEO and co-owner Avi Arad, a successful former toy designer, with creations like the Pretty Ballerina doll and the Zap-it Disappearing Ink Gun. ${ }^{70}$ In 1989 , he teamed up with fellow Israeli immigrant Isaac "Ike" Perlmutter, whose company, Toy Biz, had a deal with Ron Perelman to make Marvel toys. ${ }^{71}$ Arad persuaded Perelman to send him to Los Angeles to assist Stan Lee in persuading Hollywood superheroes were viable film properties, and before long Arad supplanted Lee as Marvel's Hollywood ambassador. ${ }^{72}$ In 1996, Marvel Entertainment formed Marvel Films after the sale of its parent company New World Communications Group, with ToyBiz purchasing Marvel in $1998 .^{73}$ Once Marvel was out of bankruptcy it licensed off one of its characters, Blade, a supernatural vampire hunter who is half vampire himself, as the first feature film licensed by Marvel films to be theatrically released. ${ }^{74}$ Arad's work for Marvel in Hollywood began to pay off when New Line Cinema released Blade, starring Wesley Snipes as the titular vampire slayer, on August 21, 1998. ${ }^{75}$ Blade cost $\$ 60$ million and grossed over $\$ 130$ million worldwide; the film was a hit, and while Marvel only made $\$ 25,000$, Blade laid the groundwork for other studios to tap into their properties [See Appendix A, Appendix B]. ${ }^{76}$ Blade was also well-received by critics, although it does not have the same critical acclaim as Marvel's later films, which was impressive when one considers how comics were viewed more as "low-culture" entertainment in the 1990s than they are now. Blade was one of the first

\footnotetext{
${ }^{69}$ Dillard, "History", 8.

${ }^{70}$ David Leonard, "Calling All Superheroes," Fortune, May 23, 2007, accessed February 20, 2014,

http://archive.fortune.com/magazines/fortune/fortune archive/2007/05/28/100034246/index.htm, 2.

${ }^{71}$ Ibid., 2.

${ }^{72}$ Ibid., 2.

${ }^{73}$ Panosian, "Money Marvel," 2.

${ }^{74}$ Dillard, "History", 7.

${ }^{75}$ Regarding the Blade film see David Leonard, "Calling All Superheroes," 2 and Chris Dillard "History of Marvel Studios," 7.

${ }_{76}$ Panosian, "Money Marvel," 2.
} 
modern Marvel films, replacing the iconic spandex of comic books with a more realistic aesthetic. ${ }^{77}$ It was also the first attempt to translate Marvel characters into R-rated films, making its success even more impressive. ${ }^{78}$ Blade was also the first cinematic Marvel character to receive a sequel (Blade II, 2002) and end in a trilogy (Blade Trinity, 2004), which served to establish the idea that trilogies for superhero films could successfully work [See Appendix A, Appendix B].$^{79}$ After proving its comic book characters could help get more funding, Marvel began an exodus of licensing its characters in order to help ensure bankruptcy would never occur again, and spurred on a wave of superhero adaptations that would continue to grow and create franchises that are still released in theaters today. ${ }^{80}$ Blade kickstarted a Golden Era of Marvel Movies, pre-Marvel Studios, which would reign for the next ten years, with the most well-known and popular films being the $X$-Men and Spider-Man films. ${ }^{81}$

Blade proved Marvel characters could be successful, but it took $20^{\text {th }}$ Century Fox Pictures releasing X-Men in 2000, and Sony Pictures releasing Spider-Man in 2002, to establish comic book films as viable projects for the studios [See Appendix J, Appendix K] ${ }^{82}$ Following Blade's success, Fox returned to its X-Men roots and licensed the mutant characters for a film, choosing to also ground the film in the "real world." 83 A large aspect of the film's success was its producers' and director Bryan Singer's decision to retain the team dynamic inherent to the $X$-Men comics, rather than distancing the film from its comic book roots. In doing so, the comic fans were happy that the characters

\footnotetext{
${ }^{77}$ Dillard "History," 8.

${ }^{78}$ Ibid., 7.

${ }^{79}$ Ibid., 7.

${ }^{80}$ Ibid., 7.

${ }^{81}$ Ibid., 6 .

82 Panosian, "Money Marvel," 3.

${ }^{83}$ Dillard "History," 8.
} 
they loved were being accurately brought to life, while the film also created new fans out of people who didn't read comics. X-Men elevated the cast to stardom, its associate producer Kevin Feige to an enormously successful career at Marvel, and spawned a franchise with a \$296 million gross, supported by strong critical reviews and audience reception that prompted other studios to make their own superhero films [See Appendix D]. ${ }^{84}$ X-Men was followed by $X 2: X$-Men United (2003), another record breaking boxoffice and critical success for superhero films making \$407 million worldwide, and $X$ Men: The Last Stand (2006), a critically panned end to the trilogy despite making \$234 million domestically, the franchise's highest domestic box office, and \$459 million worldwide [See Appendix D]. ${ }^{85}$ The release of X-Men Origins: Wolverine (2009) did not add to the franchise's critical acclaim, being universally panned despite a domestic box office of $\$ 179$ million [See Appendix D]. ${ }^{86}$ Fox corrected course with X-Men: First Class (2011) and another Wolverine spin-off, The Wolverine (2013), regaining the franchise's critical acclaim and good reputation, despite the films' lower domestic box office of \$146 million and \$136 million respectively, culminating in 2014's X-Men: Days of Future Past, merging the past and present casts of $X$-Men and achieving the franchise's second highest domestic box office with $\$ 233$ million, and the franchise's best worldwide box office of $\$ 746$ million, buoyed by audience and critical rave reviews [See Appendix D]. ${ }^{87}$ Despite the franchise's ups and downs, $X-M e n$ is a classic superhero franchise, with Fox continuing to use its license to its advantage, as Sony did with Spider-Man. ${ }^{88}$

\footnotetext{
${ }^{84}$ Panosian, "Money Marvel," 3.

85 "X-2: X-Men United," Box Office Mojo, web, http://boxofficemojo.com/movies/?id=x2.htm; "X-Men: The Last Stand," Box Office Mojo, web, http://boxofficemojo.com/movies/?id=x3.htm. All entries accessed October 16, 2014. 86 "X-Men Origins: Wolverine," Box Office Mojo, web, accessed October 16, 2014. http://boxofficemojo.com/movies/?id=wolverine.htm.

87 X-Men: First Class," Box Office Mojo, web. http://www.boxofficemojo.com/movies/?id=xmenfirstclass.htm; "The Wolverine," Box Office Mojo, web, http://boxofficemojo.com/movies/?id=wolverine2.htm; "X-Men: Days of Future
} 
Sony, who had bought the web-slinger's rights in the 1980s, followed Fox's lead by releasing Spider-Man in $2002 .^{89}$ It was the first contemporary film in cinematic history to have a $\$ 100+$ million opening weekend, and launched a highly lucrative franchise. ${ }^{90}$ The Spider-Man franchise went on to gross $\$ 822$ million in the first film, \$784 million for the second, \$891 million for the third, \$752 Million in the 2012 Amazing Spider-Man remake and \$708 million in the 2014 sequel The Amazing Spider-Man 2, ultimately having earned $\$ 3.9$ billion for the studio [See Appendix C]. ${ }^{91}$ Until recently, Spider-Man was the most successful franchise to come from Marvel, both financially and critically. ${ }^{92}$ The first film was nominated for several Academy Awards, which was a first for superhero adaptations; Spider-Man 2 (2004) until it brought home an Oscar for Best Visual Effects. ${ }^{93}$ While the first two Spider-Man films were beloved by critics and audiences, the original trilogy would end with poor critical reviews and middling audience reception for Spider-Man 3 (2007), and lead to Sony willingly reinventing the entire character and series in 2012 with The Amazing Spider-Man. ${ }^{94}$ Both Fox and Sony have kept their respective Marvel properties active in order to retain the rights and prevent the characters they have licensed from reverting back to Marvel ownership. ${ }^{95}$ Unfortunately for Hollywood, the non-X-Men and Spider-Man films superhero films released prior to 2008 have less than stellar critical reputations, despite decent box office returns.

Past," Box Office Mojo, web. http://boxofficemojo.com/movies/?id=xmen2014.htm. All entries accessed October 16, 2014.

${ }_{88}^{80}$ Panosian, "Money Marvel," 3.

${ }^{89}$ Ibid., 3.

${ }^{90}$ Ibid., 3 .

${ }^{91}$ Referring to the Spider-Man movie grosses see Diane Panosian "Behind The Money of Marvel's Mighty Movies," 3 and Box Office Mojo's "The Amazing Spider-Man 2."

92 Dillard "History," 8.

93 Panosian, "Money Marvel," 3.

${ }^{94}$ Ibid., 3.

95 Ibid., 3. 
The runaway success of $X$-Men and Spider-Man led to a bounty of superhero films, with mixed results. Daredevil, another Marvel property licensed to Fox, was released in 2003, with Ben Affleck wearing the shoes of the vigilante blind lawyer. ${ }^{96}$ Despite Daredevil earning \$102 million, it was detested by critics and audiences, along with its sequel Elektra, which earned a paltry \$24 million domestically [See Appendix D]. ${ }^{97}$ That same year, The Hulk looked to make a return to popularity after losing his television series, The Incredible Hulk, in the 1980s. ${ }^{98}$ Ang Lee (Crouching Tiger, Hidden Dragon), was hired by Universal Studios, who had licensed The Hulk, to bring to life the emotion-fueled rage creature for the public. ${ }^{99}$ Unfortunately, the film only earned $\$ 132$ million domestically and was largely rejected by audiences, with critical reviews praising its ideas and themes but calling attention to its fumbled execution [See Appendix B]. ${ }^{100}$ In 2004, Lionsgate attempted to replicate Blade's R-rated success with The Punisher. ${ }^{101}$ Despite obtaining an $\mathrm{R}$ rating, the film did not gain critical or audience traction, and bombed with $\$ 33$ million in the domestic box office [See Appendix B]. ${ }^{102}$ The Punisher only served to water down the already increasing lot of superhero films taking over the market; its reboot in 2008, Punisher: War Zone, was even a worse failure domestically and critically, earning $\$ 8$ domestically [See Appendix E]. ${ }^{103}$ The studios, despite the growing pile of misfires, still wanted to take a shot at the superhero genre and to make

\footnotetext{
${ }^{96}$ Dillard "History," 8.

97 "Daredevil," Box Office Mojo, web, http://boxofficemojo.com/movies/?id=daredevil.htm; "Elektra," Box Office Mojo, web, http://boxofficemojo.com/movies/?id=elektra.htm. All entries accessed October 16, 2014.

${ }^{98}$ Dillard "History," 8.

${ }^{99}$ Ibid., 8.

100 "The Hulk," Box Office Mojo, web, accessed October 16, 2014, http://boxofficemojo.com/movies/?id=hulk.htm.

${ }^{101}$ Dillard "History," 8.

102 "The Punisher," Box Office Mojo, web, accessed October 16, 2014, http://boxofficemojo.com/movies/?id=punisher.htm.

${ }^{103}$ Referring to the Punisher films see Box Office Mojo "Punisher: War Zone," and Chris Dillard "History of Marvel Studios."
} 
comic book money. ${ }^{104}$ Fox brought comics" "first family" to life on the screen, releasing Fantastic Four in 2005 and included a cast of A-list actors, consisting of Jessica Alba, Michael Chiklis, and Chris Evans (who ironically would later become Captain America in 2011). ${ }^{105}$ Fantastic Four was neither a smash nor embarrassment, earning middling (but not overly negative) reviews and audience reception, and accumulating a \$151 million domestic box office, but it did not make any aesthetic or thematic progress for the superhero genre [See Appendix D]. ${ }^{106}$ Two years later in 2007, it would receive a sequel in Fantastic Four: Rise of the Silver Surfer, which earned less than its first movie with $\$ 131$ million domestically, and received apathetic reviews [See Appendix D]. ${ }^{107}$ In that same year, Ghost Rider was released by Sony with Nicholas Cage playing the hero Johnny Blaze, earning \$115 million domestically along with critical and audience scorn [See Appendix B]. ${ }^{108} 2007$ was also the same year Spider-Man 3 was released, and marked the beginnings of a bloated genre getting past its prime.

\section{"The Founding of Marvel Studios"}

These second-tier superhero films' profits, despite their middling-to-bad critical and fan reception and reputation, along with the profits of $X$-Men and Spider-Man, gave Marvel the incentive to establish in 2007 their own studio, and make their own films "in house."109 Marvel's discontent with the money it was making from the films featuring their superhero characters was the determinant in creating their own studio. Ultimately,

\footnotetext{
${ }^{104}$ Ibid., 9 .

${ }^{105}$ Ibid., 9 .

${ }^{106}$ Ibid., 9.

107 "Fantastic Four: Rise of the Silver Surfer," Box Office Mojo, web, accessed October 16, 2014, http://boxofficemojo.com/movies/?id=fantasticfour2.htm.

108 "Ghost Rider," Box Office Mojo, web, accessed October 16, 2014, http://boxofficemojo.com/movies/?id=ghostrider.htm.

${ }^{109}$ Leonard, "Pow!," 8.
} 
Marvel was unsatisfied with the portion of cash they received from these films, but the paltry revenue from the films was offset by profits generated via additional media platforms. In 1998, Marvel made only $\$ 25,000$ from Blade, but the film proved superheroes were a viable film commodity, and made it possible for Marvel to participate in a variety of future deals that would far surpass the meager financial return from Blade. Furthermore, Marvel profited from the merchandise sales from its licensed characters; its box-office take wasn't much when Spider-Man opened in 2002, but the company sold so much merchandise that its net sales rose from \$181 million in 2001 to \$299 million in 2002. ${ }^{110}$ Profits soared from $\$ 1$ million to $\$ 80$ million over the same period. ${ }^{11}$ Unfortunately, soon after Spider-Man 2 opened in 2004, Marvel's stock dropped more than a third; Wall Street thought Marvel's sole value was Spider-Man. ${ }^{12}$ By that time, Fox had Fantastic Four and X-Men: The Last Stand in production, but those characters didn't sell merchandise like Spider-Man, who was not set to return to the screen until 2007. ${ }^{113}$ Marvel's profits from the first two Spider-Man films are unavailable to the public, but according to a Lehman Brothers analysis, Marvel's combined take was only $\$ 62$ million, from a combined $\$ 1.6$ billion worldwide box office [See Appendix C]. ${ }^{114}$ Spider-Man wasn't the only Marvel star to make lots of money for somebody else; Fox's Fantastic Four films, released in 2005 and 2007, grossed a combined \$624 million, but Marvel only made \$13 million from the films [See Appendix

\footnotetext{
${ }^{110}$ Leonard, "Calling All Superheroes," 2.

111 Ibid., 2.

112 Ibid., 2.

${ }^{113}$ Ibid., 2.

114 "Spider-Man," Box Office Mojo, web, accessed October 16, 2014, http://boxofficemojo.com/movies/?id=spiderman.htm; "Spider-Man 2," Box Office Mojo, web, http://boxofficemojo.com/movies/?id=spiderman2.htm. All entries accessed October 16, 2014.
} 
D]. ${ }^{115}$ The three $X$-Men movies, also produced by Fox, grossed a combined $\$ 2$ billion, while Marvel's total share was \$26 million [See Appendix D]. ${ }^{116}$ Marvel had had enough. Instead of depending on other studios, Avi Arad felt Marvel should produce its own movies, and the answer came from David Maisel, a Harvard MBA who started his career at Boston Consulting Group, whom Arad had met in 2004 and introduced to Perlmutter. ${ }^{117}$ As part of his long-term plan to make Marvel's second tier heroes, such as Captain America, Iron Man, and Thor, as lucrative for his company as Spider-Man, the X-Men, and the Fantastic Four had been for Sony and Fox, Maisel's idea was to fund movies with borrowed money backed by superhero movie rights. ${ }^{118}$ Perlmutter liked the idea and hired Maisel as COO and chairman of Marvel Studios, establishing the foundation of Marvel Studios' future legacy. ${ }^{119}$ The profits the Hollywood studios were making off of Marvel's characters are what ultimately drove Marvel Entertainment-in the footsteps of their own characters - to take hold of their own destiny and develop an independent studio to make their own films based on their characters, outside of the Hollywood system.

The creation of the current version of Marvel Studios in 2007 by Marvel Entertainment marked the beginning of Marvel's superhero dominance of Hollywood; only this time they were the party in control of the productions and profits. Marvel's plan was to break cinematic barriers and accomplish a goal Hollywood never attempted because it was impossible: to create a cohesive creative "universe," like the Marvel Comics universe, where all of their characters, and their films, exist. This goal of Marvel

\footnotetext{
${ }^{115}$ Leonard, "Calling All Superheroes," 2.

${ }^{116}$ Ibid., 2.

${ }^{117}$ Ibid., 2.

${ }^{118}$ Ibid., 2.

${ }^{119}$ Ibid., 2.
} 
Studios would ultimately become the "Marvel Cinematic Universe," also known as the "MCU," and utterly dominate superhero franchising in Hollywood. 


\section{CHAPTER TWO}

\section{“SOME ASSEMBLY REQUIRED": MARVEL STUDIO'S METEORIC MONOPOLY OF HOLLYWOOD}

Following the previous chapter's background on Marvel Comics and in-depth examination Marvel's involvement in film, this chapter will review Marvel's ascent from 2008 onwards as one of the most successful studios in Hollywood. By scrutinizing the circumstances surrounding the creation of Marvel Studios, a better comprehension of the risks and intricate planning involved in Marvel's plan to create a "Marvel Cinematic Universe" [hereafter referred to as the "MCU"] is gained. Marvel Studios claims in its publicity to have organized its output of films according to three "Phases," with "Phase One" having been completed, "Phase Two" currently ongoing, and "Phase Three" planned and announced. In forming the plan, Marvel attempted to achieve creative storytelling through the hiring of engaging actors who can bring Marvel's characters to life. The meticulous organization of the "MCU" allowed Marvel Studios to plan how they wanted their cinematic universe to span out across the different creative media, and thus create the foundation for the pivotal role played by the "MCU" in today's convergence culture. The chapter details how Marvel Studios' ambitious and creative business decisions led to the commercial and artistic success of the "MCU," in particular after the unprecedented juggernaut of The Avengers (2012).

\section{Marvel's Rebirth}

Marvel Studios' landmark deal with the Merrill Lynch, the wealth management division of Bank of America, is what gave the studio a foothold in the film and television 
industry, and begin its long-term gamble of establishing an intertwined cinematic superhero universe. ${ }^{120}$ After Spider-Man 3's commercial success, but critical failure, in 2007 business was bleak. The ratio of superhero-film hits to misses was starting to even out for the studios committed to the genre, and investors were becoming anxious. ${ }^{121}$ Ike Perlmutter, made CEO of Marvel Entertainment in 2005, enlisted David Maisel, COO and chairman of Marvel Studios, to secure the credit to fund their ambitious cinematic plans. ${ }^{122}$ The deal between Marvel Studios and Merrill Lynch, negotiated by Maisel and finalized in 2005, issued the studio a revolving credit facility, a type of loan secured by collateral where if the borrower defaults, the issuer can seize the collateral but cannot pursue the borrower for further compensation, even if the collateral does not cover the full defaulted amount. ${ }^{123}$ The loan secured \$525 million, enabling Marvel to produce ten films, which were to be distributed by Paramount Pictures. ${ }^{124}$ The deal enabled Marvel to do three things: first, Marvel would keep all the profits from its superhero movies. ${ }^{125}$ Second, Marvel would determine the film's release dates, which would make it easier to coordinate the films with the selling of action figures and other merchandise. ${ }^{126}$ Lastly, Marvel would be allowed to use the publicity and buzz generated by the pending movies to institute further licensing deals. ${ }^{127}$ However, there was a major caveat to their deal; Marvel put up the film rights of the characters they still controlled - ie. Iron Man,

\footnotetext{
120 “About Merrill Lynch,” Merrill Lynch: Bank of America Corporation, 2014, accessed November 6, 2014, http://www.ml.com/index.asp?id=7695 8134.

${ }^{121}$ Chris Dillard, "History of Marvel Studios." ComicUI, March 31-April 2, 2014, accessed April 12, 2014, http://news.comicui.com/2014/03/history-of-marvel-studios-part-1/,3.

${ }^{122}$ Referring to the merger see Jonah Welland "Isaac Perlmutter New CEO Marvel Enterprises," 2 and Devin Leonard "Calling All Superheroes," 2.

123 "Non-Recourse Debt," Investopedia, LLC, 2015, accessed January 16, 2015, http://www.investopedia.com/terms/n/nonrecoursedebt.asp.

${ }^{124}$ Diane Panosian, "Behind The Money of Marvel's Mighty Movies," Studio System News, May 2, 2013, accessed February 20, 2014, http://www.studiosystemnews.com/behind-the-money-of-marvels-mighty-movies/ 2 .

${ }^{125}$ David Leonard, "Calling All Superheroes," Fortune, May 23, 2007, accessed February 20, 2014, http://archive.fortune.com/magazines/fortune/fortune archive/2007/05/28/100034246/index.htm, 2.

${ }^{126}$ Ibid., 2.

${ }^{127}$ Ibid., 2 .
} 
Captain America, Nick Fury etc. - as collateral. ${ }^{128}$ In spite of the enormous risk of the Merrill Lynch deal, the studio ignored criticism that Marvel was relying too heavily on secondary characters, stating audiences would come for Iron Man et al., because Marvel is a powerful brand like Disney or Pixar. ${ }^{129}$ Marvel Studios' gamble ultimately lead to a new power structure within Marvel and Marvel Studios.

The shake-up of the Merrill Lynch deal led to a new hierarchy within the studio, and the firm establishment of its creative and business approaches. There was dissent and disagreement regarding Marvel's larger plan, and Avi Arad, who held the titles of CEO, Chairman and creator of Marvel Studios, resigned the following year in $2006 .{ }^{130}$ Despite playing a key role in establishing Marvel Studios, successfully selling the idea to Wall street and personally calling Brad Grey, the CEO of Paramount Pictures, to arrange distribution, Arad feared Maisel wanted to produce too many movies, too fast, and that Marvel was putting too many weak characters in the lineup. ${ }^{131}$ In May 2006, Arad left Marvel and cashed out almost all of his stock for \$59 million, despite remaining one of the producers of Iron Man and The Incredible Hulk. ${ }^{132}$ As a result, Kevin Feige was named studio chief and president of Marvel Studios in 2007. Marvel Studios' reputation and stature have endured since Iron Man's release in 2008, in no small part due to their stringent business and financial regimens.

After the careless business and financial blunders made by their former owner, Cadence Industries, Marvel successfully ran a tight and efficient financial ship, beginning

\footnotetext{
${ }^{128}$ Devin Leonard, “The Pow! Bang! Bam! Plan to Save Marvel, Starring B-List Heroes,” Bloomberg Businessweek, April 2, 2013, accessed April 20, 2014, http://www.businessweek.com/printer/articles/192489-kevin-feige-marvelssuperhero-at-running-movie-franchises, 4.

${ }^{129}$ Ibid., 2.

${ }^{130}$ Leonard, "Pow!," 3.

${ }^{131}$ Leonard, "Calling All Superheroes," 2.

${ }^{132}$ Ibid., 2.
} 
by stabilizing the larger company itself. Isaac Perlmutter brought in Peter Cuneo, who was CEO of Marvel in July 1999 for a three-year turnaround that was completed by the end of 2002. ${ }^{133}$ Marvel was not in good shape; at one point in 2000, the company had only $\$ 3$ million in the bank, barely enough to cover its cash needs. ${ }^{134}$ There were only 250 employees, no facilities that could be closed to cut costs, and the company's stock fell as low as a dismal 96 cents per share. ${ }^{135}$ With six previous successful turnarounds on his résumé, including Remington and divisions of Black \& Decker and Clairol, Cuneo knew Marvel would require both short-term fixes to put cash in the bank and new strategies to generate long-term revenue, especially with Marvel burdened with $\$ 250$ million in high-yield debt and 11 million shares of preferred stock. ${ }^{136}$ Cuneo, in his interview with journalist Robert Reiss in "How Marvel Became a Business Superhero," in the February 1, 2010 issue of Forbes, stated that the most significant strategic decision behind Marvel's turnaround was adopting a licensing model for all forms of media, such as movies and television, and for consumer products such as clothing and school supplies. ${ }^{137}$ This method served to maximize the exposure of the Marvel brand worldwide in a short amount of time, focusing on the existing library of successful intellectual properties that were recognizable to the public (Spider-Man, the Hulk, Captain America, etc.), rather than assuming greater risk by creating new content. ${ }^{138}$ Marvel then licensed out to the toy industry for action figures and role-playing games,

\footnotetext{
${ }^{133}$ Robert Reiss, "How Marvel Became a Business Superhero," Forbes, February 1, 2010, accessed February 20, 2014, http://www.forbes.com/2010/02/01/peter-cuneo-marvel-leadership-managing-turnaround.html, 1.

${ }^{134}$ Ibid., 1.

135 Ibid., 2.

${ }^{136}$ Ibid., 2

${ }^{137}$ Ibid., 2.

${ }^{138}$ Ibid., 2.
} 
which had previously been run internally. ${ }^{139}$ As a result of licensing, capital was created that Marvel then used to purchase their own bonds at 52 cents on the dollar, and effectively own themselves and make their own agenda, thus not having to be held accountable to volatile consumers and investors. ${ }^{140}$ Toys and merchandise became Marvel's largest licensed business, having issued thousands of licenses over the last decade with the benefit of committing minimal capital to them. ${ }^{141}$ As a result, Marvel retired the high-yield debt and converted the preferred shares into common shares within four years. ${ }^{142}$ Once Marvel had been stabilized through the profits and cost-saving measures of licensing, Cuneo could focus on making the company grow.

Film and video games heavily contributed to Marvel's growth, along with the rehabilitation of their original medium - the comic book. Cuneo, and Marvel, recognized that in order to grow the company the characters (and thus the brands) had to be exposed to the global general public, not only the comic book fans. ${ }^{143}$ Film and video games were the best mediums for reaching the masses. ${ }^{144}$ Film is unparalleled in its ability to generate worldwide excitement for a fantasy property, which has paid off handsomely for Marvel; since X-Men (2000) Marvel has had the best track record for worldwide box office grosses. ${ }^{145}$ Meanwhile, video games traditionally served a demographic identical to the core comic book fan base: males thirteen to thirty. ${ }^{146}$ Marvel's strategy was to spread game production among several producers so as to avoid domination by any single entity; as of 2010, video game revenue was Marvel's second largest merchandise

\footnotetext{
${ }^{139}$ Ibid., 2.

${ }^{140}$ Ibid., 2.

${ }^{141}$ Ibid., 2.

${ }^{142}$ Ibid., 2.

${ }^{143}$ Ibid., 3 .

${ }^{144}$ Ibid., 3.

${ }_{146}^{145}$ Ibid., 3

${ }^{146}$ Ibid., 3 .
} 
contributor, after toys. ${ }^{147}$ Marvel also went back to their roots, deciding to retell their old stories so that new fans would be attracted, shortened story arcs and the number of issues it took to complete a story, and pursued new distribution channels, such as bookstores, mass merchants and convenience stores. ${ }^{148}$ The result was that Marvel's North American comic book market share grew from about $25 \%$ in 1999 , to between $45 \%$ and $50 \%$ in $2010 .{ }^{149}$ Marvel's growth as a company allowed Cuneo to implement follow-on strategies for Marvel's future.

Marvel's continued success after Peter's Cuneo's completion of the turnaround in 2002 was sustained by three key strategies implemented by its Board of Directors. First, Marvel expanded their international presence, replacing their representation firms (and high commissions) with their own personnel; today, international licensing has exceeded domestic. ${ }^{150}$ The second decision was to self-produce Marvel animated television shows, including Ultimate Spider-Man (2012) and Avengers Assemble (2013), as television remains the best medium for keeping Marvel characters in front of the global public between movie releases. ${ }^{151}$ The final decision was the Merrill Lynch deal to launch Marvel's in-house movie studio in 2005: Marvel Studios. ${ }^{152}$ Peter Cuneo's tenure at Marvel, and role as Vice Chairman of Marvel's Board of Directors, was an explicit success, with Cuneo stepping down upon Disney's acquisition of Marvel. ${ }^{153}$ Marvel's ambitions and profits led to the shocking purchase of Marvel by The Walt Disney Company in 2009.

\footnotetext{
${ }^{147}$ Ibid., 3.

148 Ibid., 3.

${ }^{149}$ Ibid., 3.

${ }^{150}$ Ibid., 3.

${ }^{151}$ Referring to Marvel animation see Wikipedia "Marvel Animation" and Robert Reiss "How Marvel Became a Business Superhero," 3.

${ }^{152}$ Ibid., 3.

${ }^{153}$ Ibid., 1.
} 


\section{Disney's Acquisition}

In 2009, Marvel Studios shocked Hollywood with the announcement that it had been acquired by The Walt Disney Company, the corporation that owns Walt Disney Motion Pictures Studios, one of the major "Big Six" studios. At the time, Disney's acquisition wasn't hailed as a smart move; its stock price sank on news of the deal. ${ }^{154}$ Superheroes were hot properties in Hollywood, but in Wall Street's eyes, Disney was spending billions for a company that had years ago signed away the film rights to its most popular characters, i.e. Spider-Man and the X-Men. ${ }^{155}$ A possible reason for the ultimate success of the Marvel and Disney partnership is the similarities that exist between the two different companies.

Bob Iger, Chairman and CEO of The Walt Disney Company, foresaw endless possibility with purchasing Marvel. ${ }^{156}$ Iger had been watching Marvel closely, and had his own fair share of company turnarounds. ${ }^{157}$ He'd been named CEO of Disney in 2005 and was revitalizing the company after its troubled years under Michael Eisner. Iger had a clear strategy for Disney, like Isaac Perlmutter and Peter Cuneo did for Marvel. He believed the company needed more enduring characters, such as Mickey Mouse and Sleeping Beauty, that could be turned into movies, television shows, theme park rides, and cruise ship attractions. ${ }^{158}$ In 2006, Iger increased the population of the Disney universe with a $\$ 7.4$ billion acquisition of Pixar Animation Studios; one of the things that impressed him most were the movies Pixar had in the pipeline for the next seven years,

\footnotetext{
${ }^{154}$ Leonard, "Pow!," 1.

${ }^{155}$ Ibid., 1.

156 “Robert A. Iger," The Walt Disney Company, accessed November 14, 2014, http://thewaltdisneycompany.com/about-disney/leadership/ceo/robert-iger.

${ }^{157}$ Ibid., 2.

${ }^{158}$ Ibid., 2.
} 
among them Cars, Ratatouille, Wall-E, Up, and Toy Story $3 .{ }^{159}$ Furthermore, he recognized that Marvel's core male demographic complemented the demographic for the Disney library of characters, with some Marvel franchises, like Spider-Man, appealing to consumers of all ages. ${ }^{160}$ Iger was also impressed by how the films Marvel had in development were interconnected and primed the audience for not just one Avengers feature, but also sequels. ${ }^{161}$ Disney was also a good fit for Marvel because they knew how to develop, maintain and promote beloved characters. Mickey Mouse, Donald Duck, Goofy, and the rest of Disney's menagerie of beloved characters have maintained their popularity across generations for decades since their inception, while taking part of every aspect of creative media, from film to video games to books, and their visages on any and every piece of merchandise that can be imagined. The creative and business regimens applied to Disney's characters could also be applied to Marvel's superheroes with similar success, despite the adventures of Mickey Mouse et. al. being mostly standalone narratives rather than maintaining narrative continuity.

Despite those with misgivings about Marvel's long-term film plans, Disney proved its purchase of Marvel was well warranted with the runaway success of the Avengers. Iger believed Iron Man and Captain America would fit in nicely with Disney and Pixar characters, and eventually the two men eventually negotiated a deal. Disney would purchase Marvel, but would allow Perlmutter to remain in charge; Marvel would continue to make movies under its old system, but Disney would have final approval. ${ }^{162}$ This was a beneficial arrangement for both parties, as Perlmutter became solely focused

\footnotetext{
${ }^{159}$ Ibid., 3.

${ }^{160}$ Reiss, "Marvel Business," 3.

${ }^{161}$ Ibid., 4.

${ }^{162}$ Ibid., 4.
} 
on the operational matters of Marvel with no creative involvement in the Marvel Studios' films. ${ }^{163}$ On December 31, 2009, Disney finalized the purchase of Marvel Entertainment for $\$ 4.3$ billion dollars, for $\$ 54$ a share and bought Paramount Studios out of its final two films in its distribution deal with Marvel. ${ }^{164}$ Paramount ceded its worldwide distribution rights for Marvel Studios' Iron Man 3 and The Avengers to Disney for a minimum of $\$ 115$ million, or $9 \%$ and $8 \%$ respectively, and would continue to reap revenues generated by Marvel's films across all platforms (theatrical, home video, VOD, etc.). ${ }^{165}$ Naysayers who declared $\$ 4$ billion too high a price to purchase Marvel Entertainment were quickly proven wrong by The Avengers' $\$ 1.5$ billion dollar gross in $2012 .^{166}$

\section{Marvel Money}

Marvel Studios has long since had a reputation of being financially thrifty, perhaps even excessively so, especially in regards to negotiating acting salaries. Terrence Howard, who played billionaire Tony Stark's confidante Colonel James "Rhodey" Rhodes, a.k.a the hero War Machine, got a $50 \%$ to $80 \%$ pay cut after Marvel learned that his role as War Machine was limited. ${ }^{167}$ Howard was paid $\$ 4.5$ million for Iron Man, and despite Howard's contract suggesting he would be paid $\$ 8$ million for an Iron Man sequel, Marvel Studios countered Howards with $\$ 1$ million, but eventually Don Cheadle was recast as Rhodey when negotiations broke down. ${ }^{168}$ Mickey Rourke and Scarlett

\footnotetext{
${ }^{163}$ Ibid., 4.

${ }^{164}$ Referring to the Disney purchase please see Diane Panosian "Behind The Money of Marvel's Mighty Movies," 4 and Robert Reiss, "How Marvel Became a Business Superhero," 1.

${ }^{165}$ Panosian, "Money Marvel," 4.

${ }^{166}$ Ibid., 4.

167 "The Salaries of Marvel's The Avengers," TheRichest, July 11, 2012, accessed November 9, 2014, http://www.therichest.com/expensive-lifestyle/entertainment/marvels-the-avengers-salaries/.

${ }^{168}$ Kristy Puchko. "Terrence Howard Left Iron Man 2 Because They Would Only Pay Him \$1 Million," CinemaBlend, March 18, 2013, accessed November 9, 2014, http://www.cinemablend.com/new/Terrence-Howard-Left-Iron-Man-2Because-They-Would-Pay-Him-1-Million-36432.html.
} 
Johansson were originally offered $\$ 250,000$ for their roles as Ivan Vanko and the Black Widow, which was then negotiated to around $\$ 400,000 .{ }^{169}$ Robert Downey Jr. arguably has best advantage over Marvel. He reportedly earned \$5 million for Iron Man (2008), then $\$ 12.5$ million for Iron Man $2 .{ }^{170}$ However, Downey Jr.’s profit from Avengers was on another level, reportedly having received $\$ 70-80$ million for the blockbuster. ${ }^{171}$ This financial coup was a result of the representatives of Downey Jr. negotiating with Marvel back in 2008, when Iron Man freshly earned \$585 million worldwide, to give Downey Jr. a fraction of Marvel's revenue for any film that will feature his likeness as Iron Man, including box office bonuses and back end compensation [See Appendix G]. ${ }^{172}$ Downey Jr.'s iconic performance of the brilliant narcissistic genius Tony Stark sparked the success of Iron Man, the Avengers and the larger "MCU." Thus, if he were recast or "let go," audiences would revolt; the perfect synergy of actor and character would be impossible to replicate, making his paycheck a necessary financial evil. In contrast, all the other actors from the Avengers were said to only receive $\$ 2$ million to $\$ 3$ million for the film. ${ }^{173}$ Events came to a head in May 2013 when the cast of the Avengers held a united front against Marvel regarding salaries and compensations. ${ }^{174}$

The show of solidarity by the Avengers cast served to unnerve Marvel, which ended in hard-earned results. As reported by Nikki Finke in her article, “'Avengers' Cast And Stingy Marvel Ready To Rumble Over Sequel Cash \& Strong-Arming," the other members of the cast, including Chris Evans and Chris Hemsworth, were paid leanly for

\footnotetext{
${ }^{169}$ Kim Masters, "Haggling With the Stars," The Daily Beast, April 2, 2009, http://www.thedailybeast.com/articles/2009/04/02/haggling-with-the-stars.html. 170 "Salaries."

${ }^{171}$ Nikki Finke, “Avengers' Cast And Stingy Marvel Ready To Rumble Over Sequel Cast \& Strong-Arming," Deadline, May 7, 2013, accessed November 6, 2014, http://deadline.com/2013/05/robert-downey-jr-avengers-marvelnegotiations-fight-491675/, 1 . 
their first movies, not much better for the sequels, and were counting on at least $\$ 5$ million upfront and better back ends for the Avengers sequel. ${ }^{175}$ After hard-fought bargaining, Chris Evans for Captain America 2 and Chris Hemsworth for Thor 2 wound up with deals still weighted on the back end, but at least with attainable break-even numbers and small upfront guarantees and box office bonuses. ${ }^{176}$ Marvel threatened to sue or recast when contracts and/or options were challenged, but the cast maintained solidarity. ${ }^{177}$ As a result, Marvel and Disney were in a bind regarding the Avengers sequel because the upfront pay, backend compensation, break-even points and box office bonuses weren't yet pinned down for the cast, which was even more troubling because they didn't have Robert Downey Jr., the most essential actor, signed on for another contract. ${ }^{178}$ Downey Jr. knew his worth, stating publically "I'm what's known as a strategic cost," and added further pressure on Marvel by hinting publicly to the media that it may be time to retire Tony Stark." 179 Some of the casts' representation tried to go straight to Bob Iger or Alan Horn, the chairman of Walt Disney Studios, in hopes of discussing renegotiations since Disney purchased Marvel but were rebuffed. ${ }^{180}$ Nikki Finke, creator of Hollywood industry column Deadline, heavily suggested in her column Iger and Horn were fearful of Perlmutter, and wanted to steer clear of the nightmarish negotiations. ${ }^{181}$ Eventually a resolution came about, with Robert Downey Jr. signing for two future Avengers sequels, and other cast members striking deals, such as Scarlett

\footnotetext{
${ }^{175}$ Ibid., 2 .

${ }^{176}$ Ibid., 2.

${ }^{177}$ Ibid., 2.

${ }^{178}$ Ibid., 2.

${ }^{179}$ Ibid., 3.

${ }_{181}^{180}$ Ibid., 3.

${ }^{181}$ Ibid., 3.
} 
Johansson scoring $\$ 20$ million to reprise her role as the Black Widow. ${ }^{182}$

Despite complaints from actors, Marvel's tough approach regarding salaries allowed it to remain a profitable studio. Peter Cuneo has stated that the studio's leadership doesn't want to waste money on "non-productive spending." ${ }^{.183}$ However, he also asserts that Marvel is committed to paying for performance, and focusing on productivity from both financial and creative viewpoints, stating Marvel "made cash the core measurement for the company's success and its employees' performance metric...bonus targets were tied to cash flows rather than profitability." ${ }^{.184}$ Cuneo served as Marvel's chief executive and chief financial officer for about two years during the turnaround phase in order to save the company about half a million dollars annually. ${ }^{185}$ This action allowed Cuneo to stay close to the numbers and follow the details of Marvel's progress during that critical early stage, while maintaining a very low head count of approximately 250 employees, all full-time, with the cash flow per employee in excess of $\$ 1.5$ million. ${ }^{186}$ Marvel's stringent financial stance was needed to keep afloat and profitable in an industry where it is becoming harder to do so when people are going to the theatres less and less.

There is an element of necessity to Marvel Studios' financial thriftiness. The delicate balance of an interconnected cinematic universe, with well-known and popular characters interacting with one another on an enormous creative scale, would understandably enforce a studio's desire to safeguard themselves financially in case of failure or setbacks. However, Marvel Studios' thrifty reputation precedes them; Devin

\footnotetext{
${ }^{182}$ Referring to the casts' salary see Nikki Finke, "Robert Downey Jr. Signs For Two More 'Avengers”” and David K.

Li “\$carJo Makes' em Pay."

${ }^{183}$ Reiss, "Marvel Business," 4.

${ }^{184}$ Ibid., 4 .

${ }^{185}$ Ibid., 4

${ }^{186}$ Ibid., 5 .
} 
Leonard's article "The Pow! Bang! Bam! Plan to Save Marvel, Starring B-List Heroes” deliberately notes Marvel Studios' offices at the Disney headquarters in Burbank, California were furnished like a college dormitory, with threadbare couches. ${ }^{187}$ Nikki Finke also reports one reason why the Avengers was nominated for only one Oscar, Best Visual Effects, at the 85th Academy Awards was because Marvel refused to pay for an awards season campaign for the picture, even when Disney offered to foot the bill. ${ }^{188}$

Along with their prudent economic systems, Marvel Studios' creative regimen was another factor that contributed to the studio's success. Marvel knew in order to remain afloat and profitable in Hollywood, they had to develop unique, yet familiar, stories for their audience. Film studios normally hire outside producers to craft individual films, but Marvel decided against this process, and instead formed a sixmember creative committee consisting of personnel steeped in comic book lore. ${ }^{189}$ Its members consisted of Kevin Feige, Louis D’Esposito, co-president of Marvel Studios, and Dan Buckley, president of publishing, Joe Quesada, Marvel's chief creative officer; and Brian Michael Bendis, writer of comics hits such as Ultimate Spider-Man, the New Avengers, Alias, and the All-New X-Men, with the committee overseen by Alan Fine, the president of Marvel Entertainment. ${ }^{190}$ In Hollywood, there is an unfavorable reputation for the practice of making movies by committee; supposedly, it results in "lifeless" products. ${ }^{191}$ However, the creative-by-committee strategy worked for Marvel, and the central factor contributing to the success of Marvel Studios' films is that they aren't reinventing the wheel. They utilize epic showdowns taking place at major locations

\footnotetext{
${ }^{187}$ Leonard, "Pow!," 2.

${ }^{188}$ Finke, "Stingy Marvel."

${ }^{189}$ Leonard, "Pow!," 2.

${ }^{190}$ Referring to Marvel executives see Wikipedia "Brian Michael Bendis” and Devin Leonard, "The Pow! Bang! Bam! Plan to Save Marvel, Starring B-List Heroes," 2.

${ }^{191}$ Ibid., 2.
} 
around the world, with a liberal use of special effects, computer-generated graphics, and 3-D to keep the audience's attention. ${ }^{192}$ Nonetheless, the films feel like a refreshment of the genre, so much so that instead of diminishing returns, Marvel's sequels make progressively more money, an increasing rarity in a world where people are going to the theatres less and less due to increasing variety of entertainment options and middling quality of product. ${ }^{193}$ The Avengers sold $\$ 1.5$ billion dollars in tickets globally in 2012, making it the third-highest-grossing movie of all time; all told, Marvel has made consistent hits, which is a very difficult goal to achieve in a creative industry, even more so today [See Appendix G]. ${ }^{194}$ The intricate and innate storytelling now inherent to Marvel Studios was shepherded by its co-president, Kevin Feige.

\section{Kevin Feige}

Kevin Feige cultivated the reputation of shepherding the "MCU," after being made studio chief and president of Marvel Studios at thirty-three years old, in charge of Hollywood's first major independent movie studio since the creation of DreamWorks Studios in $1994 .{ }^{195}$ Growing up in Westfield, New Jersey, Feige was an enormous fan of film classics and franchises such as Star Wars, Indiana Jones, Star Trek, Back to the Future and Robocop. ${ }^{196}$ He decided to study film at the University of Southern California upon learning that George Lucas, the creator of Star Wars, attended the same institution. ${ }^{197}$ Upon graduating he worked as an assistant to producer Lauren Shuler Donner on three movies; the disaster flick Volcano (1997), the romantic comedy classic

\footnotetext{
${ }^{192}$ Ibid., 1.

${ }^{193}$ Ibid., 1 .

${ }^{194}$ Ibid., 1 .

${ }^{195}$ Ibid., 3 .

${ }^{196}$ Ibid., 3 .

${ }^{197}$ Ibid., 3.
} 
You've Got Mail (1998) starring the quintessential 1990s romantic duo Meg Ryan and Tom Hanks, and lastly and most infamously, X-Men (2000). ${ }^{198}$

Feige credited the success of X-Men (2000) making \$424 million worldwide to working with the director Bryan Singer to portray the mutants as they had been in the comic books: an anguished ensemble of youthful heroes torn between saving humanity and turning against it as their enemies did [See Appendix D]. ${ }^{199}$ Avi Arad was impressed, and hired Feige the same year to be his second-in-command; from then on, Feige has had a production credit with Marvel film and television shows. ${ }^{200}$ Feige concedes that Marvel most likely won't recover the film rights to all of its characters anytime soon, but believes Marvel has something more valuable: a universe of thousands of characters it controls entirely. ${ }^{201}$ That means Feige can produce an unlimited number of films with interweaving story lines and characters, creating a vast audience for almost any Marvel character, and thus any Marvel movie. ${ }^{202}$ For example, when people might show up for The Avengers, and meet the Black Widow, they can come back for her movie, too. ${ }^{203}$ Kevin Feige holds the position of the master planner of the "MCU" at Marvel Studios, while the directors execute the long-term vision of the "MCU."

\section{Marvel Studios Actors and Directors}

Marvel Studios' would not have been as successful as it is without the careful construction of its cinematic universe, and ensuring its actors remain part of its larger

\footnotetext{
198 Ibid., 5.

199 Ibid., 1.

200 Adam Rogers, "How Marvel Unified Its Movie Universe (And Why That Won’t Be Easy for DC),” Wired, August 7, 2013, accessed November 8, 2014, http://www.wired.com/2013/08/kevin-feige-marvel-dc-movies/all/.

${ }^{201}$ Leonard, "Pow!," 1.

202 Ibid., 1.

203 Ibid., 1.
} 
plan. As described by Feige his July 21, 2009 interview with The Hollywood Reporter, "unlike a major studio that makes and is responsible for twenty or so films a year, Marvel Studios only makes two films, allowing them to plan exactly what they are going to be. ${ }^{204}$ Feige further explains, "we don't develop anything that we don't plan to make, and if it does feel like we're rushing, then we change the date. ${ }^{205}$ As evident from its non-stop successes, Marvel's methods have worked so far. The studio had even hinted they have plans extending to 2028. The actors of the "MCU" are also an important factor of Marvel's success; the studio goes to great lengths to guarantee that their actors are part of their long-term plan, which they do so through the actors' contracts. Due to Marvel Studios' construction of its "MCU," it requires its actors to have multi-picture contracts. ${ }^{206}$ It is standard for major studios to sign actors for multi-picture contracts, especially when making blockbuster movies that will result in sequels. ${ }^{207}$ Marvel Studios is an extreme example of such a studio, due to how the "MCU" implies a single narrative, spanning decades of real-world production, with all of the films tying into one another like chapters in a long novel. ${ }^{208}$ The "MCU" is a continuous story, with unlimited crossover potential for its characters, and as such, Marvel's actors would have to be contracted to sign on for multiple films in order for the cinematic narrative to work. ${ }^{209}$ Samuel L. Jackson's contract is a nine-picture deal to play S.H.I.E.L.D. Director Nick Fury, which was unprecedented for its time at the time, as does Sebastian Stan, who

\footnotetext{
${ }^{204}$ Borys Kit, “The Avenger: Q\&A with Kevin Feige."," The Hollywood Reporter, July 21, 2009, accessed February 20, 2014, http://www.hollywoodreporter.com/news/qampa-kevin-feige-86744.

${ }^{205}$ Ibid.

${ }^{206}$ Gavia Baker-Whitelaw, "Being a Superhero Isn't Very Super for Marvel's “Avengers" Actors,” The Daily Dot, March 28, 2014, accessed November 6, 2014, http://www.dailydot.com/fandom/marvel-avengers-contracts-gildedcage/, 3 .

${ }^{207}$ Ibid.

${ }^{208}$ Ross Miller, “Iron Man is Forever. Robert Downey Jr. Isn't,” The Verge, October 16, 2014, accessed November 6, 2014. http://www.theverge.com/2014/10/16/6985725/marvel-iron-man-is-forever-rdj-isnt, 3.

${ }^{209}$ Referring to Marvel actors' salaries see Ross Miller, "Iron Man is Forever. Robert Downey Jr. Isn't,” 3 and Gavia Baker-Whitelaw, “Being a Superhero Isn’t Very Super for Marvel's “Avengers” Actors,” 2.
} 
portrayed Bucky Barnes in the Captain America films. ${ }^{210}$ The general contract for Marvel actors appears to be six options, when an actor is contracted to appear a certain number of times within a series of films, as Chris Evans has to portray Steve Rogers, a.k.a Captain America. ${ }^{211}$ When an actor completes, or is nearing completion of, the options in their contract they have to be paid by the studio to appear in future films. In the case of Marvel Studios, actors who have completed their contracts have the upper hand to negotiate a much higher salary than Marvel paid them in earlier films, as Robert Downey Jr. did after his contract expired after Iron Man 3, due to Marvel needing central characters such as Iron Man and Captain America. ${ }^{212}$ While completing a six-movie deal seems perfectly plausible, it means an actor is stuck in a contract for up to a decade. ${ }^{213}$ Marvel's hard edge approach to actor salaries is another pressure point. To actors like Scarlett Johansson, Chris Evans and Chris Hemsworth, who sign on for high-profile movies such as Marvel's, to stay on the A-list and fund a career doing low-budget indie movies, there is little incentive to continue with Marvel when they can earn ten times as much from a different blockbuster. ${ }^{214}$

Marvel's directors were another important aspect of Marvel Studios' success. The studio's modus operandi regarding directors for their films is to select a professional who can make their individual film unique and interesting, but still fit within the larger "MCU." Marvel tends to choose "outcast" directors, which include unexpected choices such as Jon Favreau, the Russo brothers, and James Gunn and this strategy has paid off

\footnotetext{
${ }^{210}$ Referring to cast's contracts see Michael Fleming, "Samuel Jackson Joins ‘Iron’ Cast,” 1 and Gavia BakerWhitelaw, "Being a Superhero Isn’t Very Super for Marvel's “Avengers” Actors,” 3.

${ }^{211}$ Ibid., 3.

${ }^{212}$ Robert Yaniz Jr, "Robert Downey Jr. on Iron Man Potentially Being Recast After 'The Avengers 2,"” Screenrant, November 2, 2013, accessed November 12, 2014, http://screenrant.com/avengers-2-iron-man-robert-downey-jrrecasting/.

${ }^{213}$ Baker-Whitelaw, "Being a Superhero," 3.

${ }^{214}$ Ibid.,3.
} 
for the company since Iron Man. ${ }^{215}$ Marvel's best examples of director and film synergy are illustrated through the director/film combinations of Kenneth Branagh and Thor (2011), and Joe Johnston and Captain America: The First Avenger (2011). Branagh was a perfect fit for Thor, as the film allowed him to draw upon the Shakespearean themes that permeated his other films, such as Henry V (1989) and Hamlet (1996), giving what could have been a very implausible film a solid foundation and sense of gravitas. ${ }^{216}$ Johnston had experience with the superhero genre and in creating a WWII-era genre film, as the director of the golden-age adventure film The Rocketeer (1991). ${ }^{217}$ Both professionals had experience with studio filmmaking and blockbusters, making them further ideal directorial candidates for Marvel Studios. However, as Marvel Studios build and branch out their multiple, interconnected franchises, artistic license becomes caught in the crossfire for Marvel filmmakers.

Marvel Studios' was not exempt from the tug of war that exists between business and creative forces in Hollywood. From Marvel's perspective, its characters must be informed by contractual needs, marketability and general audience expectations in order to ensure every film is a Marvel property. ${ }^{218}$ Unfortunately, adherence to this principle comes at a cost to the filmmakers, who are creatively constricted by these demands, as well as Marvel's need for a palatable product. ${ }^{219}$ This tension is best illustrated through Jon Favreau's, experience at Marvel Studios. ${ }^{220}$ The director of Iron Man, Favreau was the future model of what Marvel Studios looked for in directors, being paradoxically safe

\footnotetext{
${ }^{215}$ Referring to Marvel director decisions see Matt Patches, "The Marvel Way: How the Comic-Book Studio Chooses Its Directors," 1 and Ken Hanley, "Universally Speaking: Marvel \& The Director's Chair," 1.

216 "Kenneth Branagh,” Internet Movie Database (IMDb), N.p., n.d., web, accessed November 13, 2014, http://www.imdb.com/name/nm0000110/?ref =nv sr 1 .

${ }^{217}$ Hanley, "Universally Speaking," 6.

${ }^{218}$ Ibid., 1.

${ }^{219}$ Ibid., 1.

${ }^{220}$ Ibid., 2.
} 
and unique. He was an actor/writer, turned director with a sharp ear for comedy (having started his career at Chicago's ImprovOlympic), grew from independent film, penning his breakout Swingers (1996) and directing the film Made (2001). ${ }^{221}$ His transition to studio filmmaking with Elf (2003) showed off his ability to deliver studio-friendly fare, while Zathura (2005) touted competent action and a passion for sci-fi/fantasy, although the film was a box-office bomb. ${ }^{222}$ After the blockbuster success of Iron Man, Favreau was quickly positioned as the wunderkind of the studio, especially after the disappointment of Louis Leterrier's The Incredible Hulk (2008). ${ }^{223}$ Favreau signed on as the director for Iron Man 2 and as the executive producer of Marvel's biggest property yet, the Avengers. ${ }^{224}$ However, there were troubles; Favreau's request for more scripting time for Iron Man 2 was denied, and he unexpectedly entered production for Iron Man 2 under tumultuous conditions with the recasting of Terrence Howard. ${ }^{225}$ Favreau frequently clashed with Marvel executives, who nudged his vision aside in the name of developing their wider, Avenger-friendly universe as much as possible. Along with other setbacks, Iron Man 2 ultimately debuted to a lukewarm fan response. ${ }^{226}$ Despite being contractually tied to the company as producer on future Iron Man and Avengers productions, Favreau opted not to direct Iron Man 3. ${ }^{227}$ As a result, Marvel Studios searched for a new visionary to help craft the "MCU," and made their smartest decision in the company's history in selecting Joss Whedon. ${ }^{228}$

Joss Whedon, director of the Avengers, is in charge of maintaining the creative

\footnotetext{
${ }^{221}$ Referring to Jon Favreau's career see IMDB (IMDB) “Jon Favreau” and Ken Hanley, "Universally Speaking: Marvel \& The Director's Chair," 2.

${ }_{222}^{2}$ Ibid., 2.

${ }^{223}$ Ibid., 2.

${ }^{224}$ Hanley, "Universally Speaking," 3.

${ }^{225}$ Ibid., 3 .

${ }^{226}$ Ibid., 3 .

${ }^{227}$ Ibid., 3.

${ }^{228}$ Ibid., 4 .
} 
fires of "MCU." He could be viewed as Marvel's secret weapon, having successfully culminated "Phase One" with the runaway smash of the Avengers, and acting as Marvel Studios' creative consultant to shepherd and develop the "MCU's" long-term goals. When it was time for Marvel to make The Avengers, Feige wanted the film to explore how the different Avengers responded to each other emotionally, and knew "[the studio] needed somebody who wasn't going to reinvent the wheel, because the die was cast and the cast was cast...[but who had a] unique voice, because [the Avengers] had to feel like a part one, not Iron Man 3 or Thor 2.",229 Whedon had been on Marvel's radar since the turn of the millennium, and was heavily involved in film adaptations of comic books behind the scenes. ${ }^{230}$ He wrote a treatment for Iron Man that was approved, but had to bow out at the last minute. ${ }^{231}$ There were also brief discussions of Whedon directing $X$ Men and $X 2$ (which were ultimately directed by Bryan Singer) the first of which he script doctored, and in 2005 Whedon attempted to bring Wonder Woman to the big screen for Warner Bros., a project which unfortunately never got off the ground. ${ }^{232}$ He also became involved in writing for Marvel, diving into the X-Men universe and authoring the critically acclaimed Astonishing X-Men (2004-2008) ${ }^{233}$ When it came time to select the director for the Avengers, Feige knew Marvel needed to find a professional who could handle both action and juggle multiple storylines required in an ensemble piece. ${ }^{234}$ Whedon originally didn't want to take on the project, as he was busy with his own "Whedonverse" of properties, and originally only felt comfortable with the X-Men

\footnotetext{
${ }^{229}$ Amy Pascale, Joss Whedon: the Biography, Chicago: Chicago Review Press Incorporated, 2014, 330.

${ }^{230}$ Ibid., 330

${ }^{231}$ Ibid, 330,

232 Ibid., 263, 331.

${ }^{233}$ Referring to Joss Whedon's comics work see Amy Pascale Joss Whedon: the Biography, 235 and Wikipedia "Astonishing X-Men."

${ }^{234}$ Pascale, Joss Whedon, 330.
} 
universe. ${ }^{235}$ However, after a discussion about the current version of The Incredible Hulk script with screenwriter Zak Penn, Whedon became hooked on the "MCU."236 Between the end of filming on Thor and the start of filming Captain America: The First Avenger, Feige and Whedon met and Feige explained the Avengers script and laid out how each film related to the next. ${ }^{237}$ Whedon in turn scrapped the script and wrote five pages of material explaining how he would tell the story of the Avengers, and was promptly hired. ${ }^{238}$ Joss Whedon's role as director of the Avengers, and larger influence as Marvel Studios' creative consultant was the beginning of a mutual partnership.

Joss Whedon may have been Marvel Studios' riskiest choice at the time, but their decision to hire him as the Avengers' director and Marvel Studios' creative consultant benefited the studio enormously in the long run. Joss Whedon's role as Marvel Studios' central creative consultant, began with involvement of the post-production of Thor, and a dialogue polish and rewrite of Captain America: The First Avengers, contributing the film's tear-jerking conclusion. ${ }^{239}$ He has also overseen the development of Marvel Studios "Phase Two" films and the studio's venture in prime-time television with Marvel's Agents of S.H.I.E.L.D., following the lives and adventures of S.H.I.E.L.D. agents. $^{240}$ Whedon was also instrumental in selecting Mark Ruffalo; as the new Hulk after negotiations with Edward Norton broke down. Ironically Louis Leterrier, The Incredible Hulk's director, originally wanted Ruffalo for the role of Bruce Banner. ${ }^{241}$ Whedon also cast Colbie Smulders (How I Met Your Mother, Delivery Man), who had

\footnotetext{
${ }^{235}$ Ibid., 332.

${ }^{236}$ Ibid., 333.

237 Ibid., 333.

${ }^{238}$ Ibid., 333.

${ }^{239}$ Referring to Joss Whedon's rewrites see John Wilding. "Marvel Studios Clash with THE AVENGERS 2 Stars Over Money; Cast Threatening to Quit?," and Amy Pascale Joss Whedon: the Biography, 335.

${ }^{240}$ Ibid., 378.

${ }^{241}$ Ibid., 366.
} 
been his choice as the titular character for his Wonder Woman film as S.H.I.E.L.D. agent Maria Hill, an integral supporting character of the Avengers. ${ }^{242}$

Although Marvel had utilized other non-blockbuster directors, such as Jon Favreau and Kenneth Branagh, those professionals had film experience; Whedon had directed just one feature film, Serenity, the film sequel to Whedon's cult classic Firefly. ${ }^{243}$ However, in hiring Whedon, Marvel Studios hired a successful "showrunner," a creator with experience interweaving ensemble arcs into television and comic books. ${ }^{244}$ When it became clear that Iron Man, Thor, and Captain America were building toward The Avengers, Marvel embraced small-screen logic for big-screen storytelling. ${ }^{245}$ Furthermore, as the creator of the iconic television shows Buffy the Vampire Slayer (1997-2003), Buffy’s spinoff Angel (1999-2004), the cult classic space-Western Firefly (2002-2003) and its film sequel Serenity (2005), and Dollhouse (2009-2010), Joss Whedon's reputation made the fans confident in Marvel's choice of director for the Avengers. ${ }^{246}$ This confidence is further emphasized by Feige's support of Whedon, as he emphasized "if you look at what [Joss] did with his television work and his Marvel comics, the characters always shine through."247 Whedon's involvement at Marvel Studios not only benefits the studio, but himself as well. As reported by journalist Nikki Finke, Whedon reportedly has a deal with Marvel Studios worth an impressive $\$ 100$ million dollars for a combination of product and services including several films,

\footnotetext{
${ }^{242}$ Referring to Cobie Smulder's casting see Amy Pascale Joss Whedon: the Biography, 271, 337 and Internet Movie Database (IMDB) "Cobie Smulders."

${ }^{243}$ Pascale, Joss Whedon, 333.

${ }^{244}$ Matt Patches, "The Marvel Way: How the Comic-Book Studio Chooses Its Directors," Grantland, November 6, 2013, accessed March 20, 2014, http://grantland.com/hollywood-prospectus/the-marvel-way-how-the-comic-book-studio-chooses-itsdirectors/?src=mobile, 4 .

${ }^{245}$ Ibid., 4.

${ }^{246}$ Referring to Joss Whedon's filmography see Amy Pascale Joss Whedon: The Biography, 333 and Internet Movie Database IMDB "Buffy the Vampire Slayer," "Angel," "Firefly," "Serenity," "Dollhouse."

${ }^{247}$ Leonard, "Pow!," 10.
} 
consulting work, a pilot on ABC that eventually became the television show Marvel's Agents of S.H.I.E.L.D. and many other projects that effectively take him off the marketplace for years to come. ${ }^{248}$ After the immense success of Avengers, and "Phase One," Marvel Studios entered "Phase Two," now in the position to pursue any director they want.

Although they now had the freedom to select any director, Marvel Studios made the decision to continue choosing easily malleable, but unique and talented, directors. For Iron Man 3, Marvel recruited Shane Black, esteemed screenwriter of action hits Lethal Weapon (1987) and The Long Kiss Goodnight (1996), Black had previously worked with Robert Downey Jr. in his directorial debut, Kiss Kiss Bang Bang (2005), which was an instrumental film in Downey Jr.'s comeback after his jail time and past drug use. ${ }^{249}$ Hiring Black was a successful proposition, as Iron Man 3 became the second highest grossing film in the "MCU" to date with $\$ 1.2$ billion dollars. ${ }^{250}$ The other "Phase Two" films had more difficulties. After talks with HBO regular director Brian Kirk fell through, Thor: The Dark World was initially to be directed by Patty Jenkins, the director of Monster (2003), a favorite of Thor star Natalie Portman, and the first female director on a Marvel Studios production. ${ }^{251}$ Unfortunately, Jenkins left production when creative restrictions left her unsatisfied with the project. ${ }^{252}$ Shortly after, Marvel recruited Game of Thrones director Alan Taylor, who, like Joe Johnston, was familiar with thematically

\footnotetext{
${ }^{248}$ Finke, "Stingy Marvel," 4.

${ }^{249}$ Referring to Robert Downey Jr.'s career pre-Iron Man see (IMDB) Internet Movie Database "Shane Black" and Ken Hanley, "Universally Speaking: Marvel \& The Director's Chair," 4.

250 “Iron Man 3," Box Office Mojo, web, accessed November 13, 2014, http://boxofficemojo.com/movies/?id=ironman3.htm.

${ }^{251}$ Ibid., 5 .

${ }^{252}$ Ibid., 5.
} 
similar material and could be trusted to deliver what Marvel expected. ${ }^{253}$ However, Taylor was dissatisfied by last minute script polishes from Whedon to add more comedy to the project, and was vocally opposed to the post-production choices on the film. ${ }^{254}$ Additional rumors of Taylor being locked out of the editing bay spreading around the Internet added further fuel to the fire. ${ }^{255}$ Taylor even expressed frustration towards Marvel for their standard post-credit stingers (scenes that lay the groundwork for continuity and future Marvel films), feeling as though the scene, shot unbeknownst to him, was tonally inappropriate for the film. ${ }^{256}$ Captain America: The Winter Soldier also had a strange beginning finding their directors. After taking pitches from many potential directors, Marvel chose Anthony and Joe Russo, who came from the world of independent comedies and honed their skills in television, with programs such as Arrested Development (2003-2005), Community (2009-2014) and Happy Endings (20112012). ${ }^{257}$ The choice was puzzling at first, as the Russo brothers had been unproven with the material and budget, but Marvel's instincts were proven right again, as Captain America: The Winter Soldier grossed over $\$ 700$ million worldwide, causing the studio to quickly option the Russos for Captain America $3{ }^{258}$ Marvel Studios' announcement of the Russo brothers as the directors of the Avengers: Infinity War P.1 and P. 2, further cemented their confidence in the duo. ${ }^{259}$

Ironically, the selection of the director for Marvel's riskiest film for "Phase Two,"

\footnotetext{
${ }^{253}$ Ibid., 5 .

${ }^{254}$ Ibid., 6

${ }^{255}$ Ibid., 6.

${ }^{256}$ Ibid., 6.

${ }^{257}$ Referring to the Russo bros.' careers see (IMDB) Internet Movie Database "Anthony Russo" and "Joe Russo," and Ken Hanley, "Universally Speaking: Marvel \& The Director's Chair," 5.

${ }_{258}$ Ibid., 6 .

${ }^{259}$ Borys Kit, "Russo Brothers to Direct 'Avengers: Infinity War' Part 1 and 2," The Hollywood Reporter, March 23, 2015, accessed March 23, 2015, http:/www.hollywoodreporter.com/heat-vision/russo-brothers-direct-avengersinfinity-783685, 1 .
} 
Guardians of the Galaxy (2014), was untroubled. ${ }^{260}$ Marvel took a pitch from James Gunn, director of gross-out horror comedy Slither (2006) and violent dark superhero satire Super (2012), on the recommendation of Joss Whedon. ${ }^{261}$ Despite, Gunn's risqué and offbeat resume, Marvel signed Gunn quickly for what was expected to be their most epic, expansive film to date. ${ }^{262}$ Gunn's script inspired confidence in Marvel, who trusted the filmmaker to introduce a new batch of unfamiliar, yet important characters, to mainstream audiences, and the result was a breakout success exceeding even Iron Man, with Guardians of the Galaxy making \$333,079,971 domestically [See Appendix G]. ${ }^{263}$ Working for Marvel has provided career boost for the majority of its directors. Jon Favreau used the momentum from directing his Iron Man films to make Cowboys and Aliens (2011) and Kenneth Branagh directed and starred in Paramount's Jack Ryan remake, Jack Ryan: Shadow Recruit (2014), and directed a live-action version of Cinderella (2015) for Disney, while Alan Taylor is slated to direct the Terminator remake, Terminator: Genisys, and Shane Black is attached to a Doc Savage remake. ${ }^{264}$ Despite Marvel Studios' at times tenuous relations with its directors, their curation of their individual franchises has been successful in keeping fans interested in the larger "MCU," while creating new audiences for films featuring the Marvel characters.

\footnotetext{
${ }^{260}$ Ibid., 6.

${ }^{261}$ Referring to Marvel Studio's hiring of James Gunn see (IMDB) Internet Movie Database "James Gunn" and Ken Hanley, "Universally Speaking: Marvel \& The Director's Chair," 6.

${ }^{262}$ Ibid., 6.

${ }^{263}$ Regarding the success of Guardians of the Galaxy see Box Office Mojo "Guardians of the Galaxy" and Ken Hanley, "Universally Speaking: Marvel \& The Director's Chair," 6.

264 Regarding directors' careers see Internet Movie Database (IMDb) "Jon Favreau," "Kenneth Branagh," and "Shane Black."
} 


\section{Marvel Studios Maintenance}

Marvel Studio's deliberate crafting of each of the individual franchises of the "MCU" as a specific genre was essential to the company's strategy. Marvel developed Iron Man, and its franchise, as a "grounded" superhero film centered on real-life issues of politics, weapons drama and terrorism, while Thor was a Shakespearean fish out of water tale that expanded into epic fantasy for its sequel. Captain America: The First Avenger was a traditional "let's defeat the Nazis!" WWII actioner, whose sequel is a 1970s political and espionage thriller, while Guardians of the Galaxy has firmly established itself as an irreverent, wacky space opera. ${ }^{265}$ Marvel's "Phase Three" follows that pattern of genre curation. Scott Derrickson, the director of horror films The Exorcism of Emily Rose (2005) and Sinister (2012), will take on Doctor Strange (2016), grounding the film in the supernatural and mysticism appropriate to the character. ${ }^{266}$ Marvel's hiring of Peyton Reed, director of comedies Down with Love (2003) and Yes Man (2008), after Edgar Wright, who had been attached to the project since 2006, left production suggests an attempt to create a broad comedic heist film. ${ }^{267}$ Ultimately, the lesson regarding the choice of directors by Marvel Studios is that any and all risks come with a threshold. While James Gunn and the Russo brothers each posed their unique risks in "Phase Two" of the "MCU," they were able to tailor their directorial sensibilities to Marvel's larger plan. ${ }^{268}$ They also came with the approval of Joss Whedon, as part of the master plan for Avengers: Age of Ultron, in comparison to the directors who had more specific visions

\footnotetext{
${ }^{265}$ Ibid., 4.

266 “Scott Derrickson," Internet Movie Database (IMDb), N.p., n.d., web, accessed November 13, 2014, http://www.imdb.com/name/nm0220600/?ref =nv sr 1 .

${ }^{267}$ Referring to Peyton Reed see Internet Movie Database (IMDb), "Peyton Reed" and Rodrigo Perez, "Why Edgar Wright Left Marvel's 'Ant-Man': Analysis \& The Screenplay Rumors."

${ }^{268}$ Hanley, "Universally Speaking," 6.
} 
for their films, such as Alan Taylor and Edgar Wright. ${ }^{269}$ Marvel's careful construction of their individual franchises, and how they relate to the larger "MCU," makes their films stand out amongst the increasing volume of superhero films catering to audience consumption. Iron Man's breakout success launched Marvel Studios, and caused Hollywood to sit up and take notice, while laying the foundation for the "MCU."

\section{Marvel Studios: Phase One}

Iron Man, released May 2, 2008, was the first entry in the nascent "MCU" and Marvel Studios" "Phase One" of this universe; it needed to succeed, or else their plans for a cinematic universe would be for naught. ${ }^{270}$ It was the first film made under Marvel's Merrill Lynch deal, and there were immediate doubts in Marvel deciding to use the second-tier (at the time) character of Iron Man as the lynchpin for the studio's cinematic universe. ${ }^{271}$ Adding further fuel to the fire was Kevin Feige and Jon Favreau's decision to hire Robert Downey Jr. to play Tony Stark. ${ }^{272}$ Due to previous addictions and legal trouble, Downey Jr. was one of the highest-risk actors in the industry, to the point where he could not be insured. ${ }^{273}$ Marvel Studios had no experience in making films and had yet to establish themselves as a proven company. Before 2008, Iron Man, and the Avengers comic book series, were nowhere near the household names they are now. ${ }^{274}$ These were huge risks, even for superhero films. ${ }^{275}$ Ultimately, Marvel Studios' biggest risk was rewarded, with Robert Downey Jr.'s nuanced and bombastic portrayal of Tony

\footnotetext{
${ }^{269}$ Hanley, "Universally Speaking," 6.

270 "Iron Man," Box Office Mojo, web, accessed November 16, 2014, http://boxofficemojo.com/movies/?id=ironman.htm.

${ }^{271}$ Referring to Iron Man's role in the "Marvel Cinematic Universe" see Diane Panosian "Behind The Money of Marvel's Mighty Movies," 4 and Chris Dillard "History of Marvel Studios," 4.

${ }^{272}$ Panosian, "Money Marvel," 4.

${ }^{273}$ Dillard "History," 4.

${ }^{274}$ Ibid., 4.

${ }^{275}$ Ibid., 4.
} 
Stark becoming the standard for character and actor synchronicity, of the actor embodying a character so well that he or she becomes inextricably linked to the character in the minds of the public. ${ }^{276}$ Iron Man also hedged its bets with the inclusion of big name and respected actors, including Jeff Bridges (The Big Lebowski, True Grit) as antagonist Obadiah Stone, and Gwyneth Paltrow (Se7en, Shakespeare in Love) as Virginia "Pepper" Potts. ${ }^{277}$ These actors helped ground the film in reality, and give Iron Man a more serious quality. ${ }^{278}$ In hindsight, Marvel selecting Iron Man as its first film was a smart strategic move. The character of Iron Man is a superhero whose origins, as a rich genius industrialist who builds himself a weaponized suit to save himself, then uses the suit to save others, is within the realm of plausible possibility; it allowed audiences to better connect with its protagonist. Iron Man's more realistic tone, along with Marvel updating the story to address current issues such as terrorism and warfare, and partially taking place in present-day Afghanistan, offered a refreshing change of pace from the often-fantastical superhero films that preceded it. ${ }^{279}$ The film also began the unprecedented construction of a larger superhero "cinematic universe." At the end of Iron Man, after the credits, the studio included a special scene that included Director of S.H.I.E.L.D. Nick Fury, portrayed by Samuel L. Jackson, the biggest-name actor in the film's cast at the time. ${ }^{280}$ Kevin Feige has since stated, "that [scene] was a stunt and a treat for fans," but it also was a landmark moment in superhero film history. ${ }^{281}$ In less then a minute, Marvel Studios set up the expectation that future films would lead to an

\footnotetext{
${ }^{276}$ Panosian, "Money Marvel," 4.

277 "Gwyneth Paltrow," Internet Movie Database (IMDb), N.p., n.d, web, accessed November 16, 2014, http://www.imdb.com/name/nm0000569/?ref =nv sr 1; "Jeff Bridges," Internet Movie Database (IMDb), N.p., n.d, web, http://www.imdb.com/name/nm0000313/?ref =nv sr 1. All entries accessed November 16, 2014.

${ }^{278}$ Dillard "History," 4.

279 Ibid., 4.

${ }^{280}$ Ibid., 4.

${ }^{281}$ Paul Bond and Borys Kit, "Marvel's Machine in Gear," The Hollywood Reporter, May 6, 2008, accessed February 20, 2014, http://www.hollywoodreporter.com/news/marvels-machine-gear-110880, 2.
} 
Avengers feature, prior to establishing any superhero characters other than Iron Man through the studio. ${ }^{282}$ With this bold move, Marvel Studios definitively laid the groundwork for cinematic continuity with Marvel's history in comics via characters who reference and interact with one another across multiple films. ${ }^{283}$ This continuity, which was unprecedented in Hollywood, was enough to entice comic book fans and the general audience to the point that if Marvel Studios did not deliver on its grand plan to become a successful studio and to establish a "MCU," the studio would collapse. ${ }^{284}$ Iron Man ended up being a huge success in both financial and critical terms, with an extremely impressive $\$ 585$ million worldwide box office, and officially silenced the naysayers of the comic book movie genre and those who frowned upon the risks that Marvel Studios took to create their first film. ${ }^{285}$ A.O. Scott's rave review for The New York Times proclaimed that “'Iron Man'... is distinguished by light touches and grace notes.... his heroism is all handicraft, elbow grease and applied intelligence. ${ }^{286}$ Paramount expanded its distribution deal with Marvel Studios to six pictures, and Marvel proved that its fiveyear goal of becoming a full-fledged movie production company was worth the wait, with investors rewarding the company by bidding its shares up $9.4 \%$ to $\$ 33.10{ }^{287}$ Marvel's share price, the highest the stock had been since going public in 1998 at a split-adjusted $\$ 4.54$, valued the company at $\$ 2.6$ billion, with Marvel posting a $\$ 45.2$ million profit in the first quarter ( 58 cents per share) besting by a wide margin the 43 cents Wall Street

\footnotetext{
282 Dillard "History," 4.

${ }^{283}$ Ibid., 5.

${ }^{284}$ Ibid., 5.

${ }^{285}$ Referring to Iron Man's success see Diane Panosian "Behind The Money of Marvel's Mighty Movies," 4 and Chris Dillard "History of Marvel Studios," 5.

${ }^{286}$ A.O. Scott, "Heavy Suit, Light Touches," The New York Times, May 2, 2008, accessed November 16, 2014, http://www.nytimes.com/2008/05/02/movies/02iron.html? r=0.

${ }^{287}$ Regarding Marvel's shares see Diane Panosian "Behind The Money of Marvel's Mighty Movies," 4 and Paul Bond and Borys Kit, "Marvel's Machine in Gear," 2.
} 
predicted. ${ }^{288}$ Iron Man cemented Marvel Studios' reputation as a powerful player in Hollywood, and paved the way for The Incredible Hulk, Iron Man 2, Thor, and Captain America: The First Avenger to enrich the world of the "MCU."289 With five films that established a large and interconnected universe and endeared characters to audiences, the stage was set for the main event: The Avengers.

The immense success of Avengers, released May 4, 2012, was the culmination of Marvel Studios' hard work and patient planning. ${ }^{290} 2012$ was the pinnacle year for comic book films and superhero exposure, with Marvel's the Avengers and Christopher Nolan's The Dark Knight Rises, the final film in The Dark Knight trilogy, showing in theatres within two months of each other. ${ }^{291}$ Adding further pressure on Marvel was that the Avengers was the only film it released in 2012, while the studio had previously released two films a year. However, the Avengers had a scheduling advantage, as it was the first blockbuster of the summer season that year. The pressure was on, as it was the most ambitious project by any studio to date, bringing together the main (and supporting) actors from five previous films and placing them into one movie. ${ }^{292}$ After deliberately developing the larger "MCU" across all of their earlier films, the Avengers was shot in ninety-two days in the spring of $2011 .^{293}$ In the Avengers, Iron Man, Thor, Captain America, the Hulk, Hawkeye, and Black Widow all took main stage as they fought against the manipulative Loki and his army of Chitauri. ${ }^{294}$ While Marvel's films often had multiple writers, Iron Man having had thirteen, the Avengers only had one: Joss

\footnotetext{
${ }^{288}$ Ibid., 2.

${ }^{289}$ Dillard "History," 4.

290 "Marvel's The Avengers," Box Office Mojo, web, accessed November 16, 2014, http://boxofficemojo.com/movies/?id=avengers11.htm.

${ }^{291}$ Dillard "History," 5.

292 Ibid., 5.

${ }^{293}$ Panosian, "Money Marvel," 4.

${ }^{294}$ Ibid, 5.
} 
Whedon. ${ }^{295}$ Marvel smartly leveraged the superheroes' prodigious brand awareness by hiring a well-known geek icon, responsible for creating some of television's most enduring and beloved shows, whose fans are some of the most dedicated and zealous in pop culture. ${ }^{296}$

Hiring Whedon was Marvel Studios' statement to the "geeks," "nerds," comic books fans, and those involved in the entertainment and pop culture industry that they meant business and were serious about the quality of the Avengers. Whedon was the perfect individual to direct and script the Avengers, bringing together so many actors and characters, while maintaining story and development, was not going to be simple or easy. ${ }^{297}$ His years on shows that featured a team of characters (Buffy the Vampire Slayer, Firefly, Dollhouse), established his ability to keep drama, humor, and character development balanced, yet still remain successful. ${ }^{298}$ Marvel's decision paid off, as The Avengers is now the highest-grossing superhero film of all time, and the third highestgrossing film of all time with a worldwide gross of $\$ 1,518,594,910$ billion dollars [See Appendix G]. "Phase One" culminated with a post-credits scene involving Thanos, a legendary Marvel Comics villain, hinting at the classic storyline of the Infinity Gauntlet. $^{299}$ The teaser proved to the fans once again that Marvel Studios meant business in bringing beloved Marvel stories to the big screen, and cemented the fans' loyalty and devotion. The success of the Avengers banished any remaining doubts about Bob Iger's \$4 billion investment in Marvel. With the Avengers, the bar had been set higher than ever before, for any series or studio's attempts at filmmaking in the future, and Marvel

\footnotetext{
${ }^{295}$ Ibid., 4.

${ }^{296}$ Ibid., 4.

${ }^{297}$ Dillard "History," 5.

${ }^{298}$ Ibid., 5.

299 Dillard "History," 5.
} 
Studios continued to build on their foundation by making their "Phase Two" films (Dillard). ${ }^{300}$

Marvel Studios: Phase Two

After Marvel Studios blasted past all expectations with the Avengers, it wisely refused to rest on its laurels and continued forward with "Phase Two." The grosses of Iron Man 3, released May 3, 2013, and Thor: The Dark World, released November 8, 2013 , rose $36 \%$ and $30 \%$ respectively from their previous corresponding franchise entries, benefiting from the Avengers" "halo" effect. Marvel Studios' consecutive films Captain America: The Winter Soldier and Guardians of the Galaxy, maintained its successes while expanding the scope of their narratives. Actions taken by Marvel Studios' following "Phase Two" films, Captain America: The Winter Soldier, released April 4, 2014, and Guardians of the Galaxy, released August 1, 2014, had serious consequences for the larger "MCU." 301 Marvel's choice of Anthony and Joe Russo, whose experience was primarily in television, over fellow finalists Tim Story (Fantastic Four) and George Nolfi (The Adjustment Bureau) to direct the second Captain America film may have seemed odd at first, but they were ultimately an inspired and smart choice. $^{302}$ The goal of television directors is to keep the narrative moving, in comparison to feature film directors, who aim to establish an individual directorial style and

\footnotetext{
${ }^{300}$ Dillard "History," 5.

301 "Captain America: The Winter Soldier," Box Office Mojo, web, http://boxofficemojo.com/movies/?id=marvel14b.htm; "Guardians of the Galaxy." Box Office Mojo. Web, http://boxofficemojo.com/movies/?page=main\&id=marvel2014a.htm. All entries accessed November 16, 2014.

${ }_{302}$ Andy Greenwald, "Introduction to Blockbuster Filmmaking: Why a Couple of Community Producers Are a Perfect Match for Marvel," Grantland, June 8, 2012, accessed November 17, 2014, http://grantland.com/hollywoodprospectus/introduction-to-blockbuster-filmmaking-why-a-couple-of-community-producers-are-an-inspired-choice-forthe-marvel-universe/, 1 .
} 
aesthetic. ${ }^{303}$ The humility and work ethic honed by television direction ultimately appealed to Marvel Studios, which chose professionals they knew could do their job and make the film they wanted, rather than linking a film, and its franchise, to a particular filmmaker and run the 50/50 chance of success or failure. ${ }^{304}$ Marvel's instincts once again rewarded them, with Captain America: The Winter Soldier receiving rave reviews, with critics praising the film's action, character development, and spy-thriller narrative, and a $48 \%$ increase in its opening weekend, culminating in a $\$ 714,083,572$ million dollar box office [See Appendix G].

Guardians of the Galaxy was Marvel Studios' riskiest property, featuring a team from one of Marvel's more obscure comic titles and consisting of characters such as a talking raccoon and living tree, while remaining only peripherally connected to the other Marvel Studios' films. Director James Gunn delivered a balancing act of zany humor and meta-references mixed with a conventional heroic narrative, a la Stephen Spielberg and George Lucas, set against a space-opera backdrop. ${ }^{305}$ The resulting film was an immensely enjoyable, yet crazy, mixture of Star Wars and Mel Brook's Spaceballs, with an aura of breezy humor throughout. ${ }^{306}$ Freed from high expectations, or any expectations at all, Gunn was able to take risks while still staying within Marvel's playbook. ${ }^{307}$ Marvel Studios' brand power and reputation, established by its consecutive successes and $\$ 6.54$ billion dollars in ticket sales worldwide, also allowed the studio to build up enough momentum to take risks and for audiences to go out on a limb with

\footnotetext{
${ }^{303}$ Ibid., 1.

${ }^{304}$ Ibid., 1.

305 Jason Concepcion, "I Feel Groot!," Grantland, August 1, 2014, accessed November 18, 2014, http://grantland.com/features/guardians-of-the-galaxy-get-on-up-review/, 6 .

${ }^{306}$ Ibid., 6.

307 John Lopez, "How 'Guardians of the Galaxy' Cherry-Bombed the Box Office and Made Off With All of Our Money," Grantland, August 4, 2014, accessed November 18, 2014, http:/grantland.com/hollywood-prospectus/howguardians-of-the-galaxy-cherry-bombed-the-box-office-and-made-off-with-all-of-our-money/, 1.
} 
unknown properties. ${ }^{308}$ Guardians of the Galaxy was a sorely needed smash hit for the film industry in a the disappointing 2014 summer box office, and was the only movie in 2014 to cross over $\$ 300$ million dollar mark, making $\$ 333,079,971$ [See Appendix G] ${ }^{309}$ Marvel Studios' most current releases have helped cement their status as the studio to beat in Hollywood, while continuing to draw healthy grosses and profits and constantly expanding their "MCU."

Marvel Studios, and its "MCU," has effectively become a game changer for superhero films and the film industry itself. By being the first studio to successfully develop a cinematic universe that could branch out in different storylines, while maintaining narrative continuity and in which multiple characters (and their potential franchises) interact with one another across multiple films, Marvel Studios establishing a new standard of superhero franchising in Hollywood. Warner Bros. is attempting to mount a "cinematic universe" equivalent for its DC Comics characters, including Superman, Batman, the Flash and its Avengers equivalent, the Justice League, while Sony Pictures and $20^{\text {th }}$ Century Fox Pictures are currently developing a similar "cinematic universes" for the Marvel properties they still possess. The unlimited possibilities of the "MCU" is reflected through the multiple forms of media it employs, from film to television to cinematic "one-shots," making it a prime example of convergence culture.

\footnotetext{
${ }^{308}$ Ibid., 3.

309 "Guardians of the Galaxy," Box Office Mojo, web, accessed November 13, 2014, http://boxofficemojo.com/movies/?page=main\&id=marvel2014a.htm.
} 


\section{CHAPTER THREE}

\section{“A FINGER IN EVERY PIE": CONVERGENCE CULTURE AND THE TRANSMEDIA NARRATIVE OF THE "MARVEL CINEMATIC UNIVERSE."}

After examining the unprecedented success of Marvel Studios and its "Marvel Cinematic Universe," [hereafter referred to as the "MCU"] this chapter will attempt to define and explore the role of transmedia storytelling in convergence culture, and how the "MCU" utilizes its franchises within a transmedia context. The classification "MCU" is misleading in that the inclusion of "cinematic" can lead casual fans to believe the "MCU" consists only of films. However, the "MCU" consists of multiple entertainment media, ranging from film to television, to comics to cinematic "one-shots" bundled in Marvel Studios' Blu-rays detailing events occurring outside of the films, but within the larger "MCU." Franchise films are known mainly as a business innovation, and are often viewed as easy "money-makers" by studios, critics, and film audiences. However, franchise films can also exhibit a distinctive artistry. The "MCU" films can be seen as comprised mainly of franchise films, but in order to appreciate the artistic development and construction of the "MCU," we need to understand these films in the context of convergence culture. The transmedia structure of the "MCU" cements its role and influence in convergence culture, and immensely contributes to its films' successes.

The origins of transmedia storytelling and convergence culture are crucial to understanding the larger influence of transmedia storytelling influence on popular culture and the entertainment industry. An influential account is provided by Marsha Kinder, who identified in the late 1980s a set of textual forms and practices of production and 
consumption that emerged at around that time as "transmedia." "310 Through exploring how children consumed film, television, and video games in tandem, Kinder observed a "transmedia intertextuality" grooming children to recognize genres, identify with characters, and perceive the value of systemic operations across media. ${ }^{311}$ Feeding this "transmedia intertextuality" were what Kinder called "entertainment super systems.",312 These properties, such as Teenage Mutant Ninja Turtles and The Muppets, could be experienced in unique ways through textual offerings in different media. ${ }^{313}$ In Chapter One of this thesis I traced important elements of this kind of intertextuality back to the comics industry of the 1940s. The presence of the seeds of convergence culture and transmedia storytelling in the comic industry demonstrates that they precede the 1980s. Overall, this chapter provides a corrective measure, illustrating how historical context is needed in over to fully understand contemporary developments within a creative industry such as film, where value is often placed upon new and breaking developments.

Kinder's concept of "transmedia intertextuality" has provided a basis for American media scholar Henry Jenkins' concept of transmedia storytelling. Henry Jenkins suggests that the forms of production that make up transmedia involve a revolution in storytelling. ${ }^{314}$ Transmedia storytelling, he proposes, amounts to "a new aesthetic that has emerged in response to media convergence - one that places new demands on consumers and depends on the active participation of knowledge

\footnotetext{
${ }^{310}$ Derek Johnson, Media Franchising: Creative License and Collaboration in the Culture Industries (New York: NYU Press, 2013), 22.

311 Ibid., 31.

312 Ibid., 31.

313 Ibid., 31.

314 Anna Zaluczkowska, "Storyworld: the Bigger Picture, investigating the world of multi-platform/ transmedia production and its affect on storytelling processes," Journal of Screenwriting 3.1 (2011): 85.
} 
communities. ${ }^{315}$ Transmedia storytelling is in turn part of a "convergence" culture; the flow of content across multiple media platforms, the cooperation between multiple media industries, and the migratory behavior of media audiences who would go almost anywhere in search of the kinds of entertainment experiences they want. ${ }^{316}$ In the world of convergence culture, there is unlimited potential to tell every possible story and sell every possible brand, with every consumer being courted across multiple media platforms. ${ }^{317}$ It is shaped and defined by the desires of media conglomerates to expand their empires across multiple platforms and by the desires of consumers to have the media what they want, where they want it, when they want it, and in the format they want. ${ }^{318}$ The role of transmedia storytelling has had a further impact on narrative, world building, and the development of creative properties.

As Jenkins illustrates through the examination of the Wachowski's The Matrix franchise in his article "Searching for the Origami Unicorn: The Matrix and Transmedia Storytelling," a transmedia story unfolds across multiple media platforms, with each new installment making a distinctive and valuable contribution to the whole story. ${ }^{319}$ For example, in The Matrix franchise, key information about the story is conveyed through three live action films, a series of animated shorts, two collections of comic book stories, and several video games. ${ }^{320}$ There is no one single source or ur-text where one can turn

\footnotetext{
315 Ibid., 85

${ }^{316}$ Henry Jenkins, "Introduction: Worship at the Alter of Convergence: A New Paradigm for Understanding Media Change," in Convergence Culture: Where Old and New Media Collide. (New York: New York University Press, 2006), 2 .

${ }^{317}$ Ibid., 2.

${ }^{318}$ Ibid., 2.

${ }^{319}$ Henry Jenkins, "Searching for the Origami Unicorn: The Matrix and Transmedia Storytelling," in Convergence Culture: Where Old and New Media Collide. (New York: New York University Press, 2006), 95.

${ }^{320}$ Henry Jenkins, “Transmedia Storytelling 101," Confessions of an Aca-Fan, March 22, 2007, accessed February 22, 2014, http://henryjenkins.org/2007/03/transmedia storytelling 101.html, 1.
} 
to gain all of the information needed to comprehend the Matrix universe. ${ }^{321}$ Ideally in transmedia storytelling, each medium maximizes its individual creative advantages so that a story might be introduced in a film, then expanded through television, novels and comics; its world-building might be explored through gameplay or experienced as an amusement park. ${ }^{322}$ Each franchise entry needs to be self-contained so a consumer doesn't need to have seen the film to enjoy the game, and vice versa. ${ }^{323}$ Any given product is a point of entry into the franchise as a whole, and experiencing the story across the media sustains a depth of experience that motivates more consumption. ${ }^{324}$ As a result, consumers cultivate a "gotta catch them all" collector mentality when consuming transmedia storytelling across multiple media of entertainment.

Transmedia storytelling complements convergence culture, offering new levels of insight and experience for fans and consumers while refreshing a franchise and sustaining consumer loyalty. ${ }^{325}$ The economic logic of a horizontally integrated entertainment industry, where a single company has roots across all of the different media sectors, dictates the flow of content across media. ${ }^{326}$ Different media attract different market niches; however, redundancy and subpar quality can burn up fan interest and cause franchises to fail. ${ }^{327}$ A good transmedia franchise works to attract multiple audiences by framing the content somewhat differently across the different media. ${ }^{328}$ In particular, if there is enough content to sustain those different installments, and if each work offers fresh experiences, then the franchise can tap into an enormous potential market and

\footnotetext{
${ }^{321}$ Ibid., 1

322 Jenkins, Convergence Culture, 96.

${ }^{323}$ Ibid., 96.

324 Ibid., 96.

325 Ibid., 96.

${ }^{326}$ Ibid., 96.

${ }^{327}$ Ibid., 96.

${ }^{328}$ Ibid., 96.
} 
expand its potential gross. ${ }^{329}$ The entertainment industries, especially the film industry, often utilize transmedia storytelling in their franchises in the hopes they will become crossover successes.

The media franchise is an important component to the concept of transmedia storytelling. Prior to the 1980 s, the term "franchise" held two primary meanings. First, the right to vote and exercise agency as the subject of an institution; and second, a retail operation, such as McDonald's or Coca-Cola, in which independent operators in local markets paid a license fee for the right to conduct ongoing business under a shared, corporate trademark. ${ }^{330}$ However, in the last thirty years the concept of the franchise has taken on a third meaning. In media and pop culture, the franchise is the multiplied replication of culture from a common intellectual property resource. ${ }^{331}$ Essentially, it is an intellectual property that can be, or has the potential to be, part of a series and spawn lucrative sequels while lending itself to merchandising. ${ }^{332}$ Robert Iger, president and CEO of Disney further describes the franchising of media content production as "something that creates value across multiple businesses and across multiple territories over a long period of time." ${ }^{333}$ Unlike stand-alone films, franchise pictures are typically high-concept, big budget and/or blockbuster films that aim for "marquee" status in a studio's annual marketing campaigns. ${ }^{334}$ Due to the large financial risk involved, such pictures can be excessively formulaic and are frequently developed from widely

\footnotetext{
${ }^{329}$ Ibid., 96.

${ }^{330}$ Johnson, Media Franchising, 6.

${ }^{331}$ Ibid., 6.

332 Stephen Wise, "Movie Terms That Should Be Returned," FilmVerse, November 30, 2011, accessed January 10, 2015, http://filmverse.com/2011/11/30/movie-terms-that-should-be-retired/.

333 Johnson, Media Franchising, 6.

${ }^{334}$ John Thornton Caldwell, Production Culture: Industrial Reflexivity and Critical Practice in Film and Television (North Carolina: Duke University Press, 2008), 264.
} 
recognized big-hit television, publishing, or comic book properties. ${ }^{335}$ Harry Potter, Star Trek and Lord of the Rings are examples of extremely profitable franchises, and of the proliferation of media franchising in popular culture. ${ }^{336}$ In television there are multiple spinoffs of Law and Order, CSI, and NCIS, and in film there is a constant rebooting of past franchises, such as James Cameron's The Terminator, or the remaking of films suitable for franchise marketing, such as the remake of The Karate Kid (1984) classic in $2010 .^{337}$ Even when a creative property reaches its narrative conclusion, the franchise can still endure through spinoffs, as with Warner Bros.' planned adaptation of J.K. Rowling's Harry Potter short story Fantastic Beasts and Where to Find Them set as three mega-movies. ${ }^{338}$ While it is unquestionable that franchises can yield unlimited profits for as long as they remain relevant, popular and maintain a level of positive critical and consumer reception, there are cons to their utilization.

The franchise, while potentially extremely profitable, has a somewhat negative and derogatory reputation amongst entertainment critics and fans. In light of the film industry and studios' wholehearted and desperate embrace of franchises, brought on by a multitude of factors such as piracy, the shrinkage of the DVD and Blu-ray market and the growth of VOD and Netflix, entertainment and media critics and consumers view franchising as an unimaginative and manufactured manner of making money, while eschewing character and narrative development and construction. In many cases, the franchise has become shorthand for creative and cultural bankruptcy, and blatantly

\footnotetext{
335 Ibid., 264

${ }^{336}$ Ibid., 2.

337 Ibid., 2.

338 Zach Dionne, “J.K. Rowling's 'Harry Potter' Spinoff Will actually Be Three 'Megamovies,'” Grantland, March 31, 2014, accessed January 11, 2015, http://grantland.com/hollywood-prospectus/jk-rowling-trilogy/.
} 
transparent ploys for its audience's money. ${ }^{339}$ As Bob Rehak, Associate Professor of

Film and Media Studies and contributor or the journals Film Criticism and Information, Communication and Society, stated in 2007, "such is the nature of the successful media franchise...doomed to plow forward under the ever-increasing inertia of its own fecund replication."340 Franchises do not necessarily denote subpar quality in storytelling and narrative, but if they are not maintained and supported by creativity and originality, they can become bland, mediocre, and utterly forgettable. While the risks of franchise banality are real, Marvel has successfully maneuvered their way to becoming one of, and arguably the, most economically and aesthetically successful modern media franchises.

Marvel Studios' success with the "MCU" is credited to its embracing of the benefits of transmedia storytelling and being able to foster a creative environment within franchise boundaries. Through transmedia storytelling, "synergy," the interaction or cooperation of two or more organizations, or agents to produce a combined effect greater than the sum of their separate effects, is created, reflecting the economics of media consolidation. ${ }^{341}$ The majority of modern media companies are horizontally integrated holding interests across a range of what were once distinct media industries. ${ }^{342}$ A media conglomerate has an incentive to spread its brand or expand its franchises across as many different media platforms as possible. ${ }^{343}$ For example, the comic books published in advance of the release of such films as Batman Begins (2005) and Superman Returns (2006), were distributed by DC Comics, which is in turn owned by Warner Bros., the

\footnotetext{
339 Johnson, Media Franchising, 2.

${ }^{340}$ Referring to Professor Bob Rehak see Swarthmore College "Bob Rehak" and Derek Johnson, Media Franchising: Creative License and Collaboration in the Culture Industries, 2.

341 "Synergy," Oxford Dictionaries.com, 2015, http://www.oxforddictionaries.com/definition/english/synergy.

${ }^{342}$ Henry Jenkins, "Transmedia Storytelling 101," Confessions of an Aca-Fan, March 22, 2007, accessed February 22, 2014, http://henryjenkins.org/2007/03/transmedia storytelling 101.html, 1.

343 Ibid., 1.
} 
studio who released the films. ${ }^{344}$ These comics provide back-story that enhance the viewer's experience of the film even as they also help to publicize the forthcoming release, thus blurring the line between marketing and entertainment. ${ }^{345}$ The current configuration of the entertainment industry makes transmedia expansion an economic imperative, and can become somewhat formulaic in its implementation. ${ }^{346}$

In spite of the rigidity of franchise-related media productions, there is much creativity that can exist within its boundaries. By nature, a media franchise provides a context in which the negotiated exchanges and identifications of industrial creativity can play out with an eye toward supervision, control, and continuity. ${ }^{347}$ However, there are media companies who utilize marketplace pressures to create genuinely compelling and immersive transmedia stories, as Marvel Studios has done with the "MCU."348 Henry Jenkins suggests that in contemporary media, "storytelling has become the art of worldbuilding, as artists create compelling environments that cannot be fully explored or exhausted within a single work or even a single medium," but there are some limitations to a theory of franchise creativity based in world-building. ${ }^{349}$ What distinguishes worldbuilding in media franchising from that in "traditional" media works is the degree to which worlds, once built, become shared among creative stakeholders working in and across multiple production sites. ${ }^{350}$ Franchising is better conceived in the terms of worldsharing than world-building, as it occurs when creative resources are exchanged across contexts of production, where sequels, spin-offs, and tie-ins ask multiple production

\footnotetext{
${ }^{344}$ Ibid., 1.

${ }^{345}$ Ibid., 1.

${ }^{346}$ Ibid., 1.

347 Johnson, Media Franchising, 142, 151.

348 Jenkins, Transmedia 101, 1.

${ }^{349}$ Johnson, Media Franchising, 108.

${ }^{350}$ Ibid., 109.
} 
communities to work in successive or parallel relation to one another. ${ }^{351}$ The "worlds" in play in a franchise thus offer a shared creative context in which many different creators and artists can then draw resources and make their own individual and original contributions, rendering their creative labor meaningful. ${ }^{352}$ The connectivity of all of the components of the "MCU" reflects a unique artistry in the cinematic universe's construction. It takes skill and talent to be able to create and develop a creative universe featuring multiple characters, each with their own individual stories. It takes even more skill to ensure that these same multiple characters team up, interact and work together, becoming part of a larger story spanning multiple creative media, from film to television to comics, all the while maintaining the individual stories of each individual character. The "MCU" is an exemplar of the intricate artistry of convergence culture, and how the construction of franchise films can be creatively and artistically rewarding, as well as financially successful.

The environment and foundations of the franchise can be stifling, for some, but for others it can provide the best possible canvas to create a narrative and bring structure to the creative field. Justin Theroux, one of the screenwriters for Iron Man 2, downplayed the relationships between filmmakers working on the projects marketed by Marvel Studios as part of the coordinated buildup to the Avengers. ${ }^{353}$ Theroux stated “there's no dialogue right now" between filmmakers, by which he meant that each director had the freedom to craft the best possible version of their film, within the boundaries dictated by Marvel Studios, rather than micro-managing over how their film

\footnotetext{
351 Ibid., 109

${ }^{352}$ Ibid., 108.

${ }^{353}$ Ibid., 108.
} 
fits within the larger "MCU.,"354 Franchising, therefore, creates unique circumstances in which to consider the nature of creative identity in industrial contexts, since the territory in which creativity occurs is by definition a shared one, and networked creators must negotiate and give meaning to that sociality in their practice. ${ }^{355}$ Cultural convergence and transmedia storytelling consist in the enrichment, a.k.a the quality, of a cultural product's content. This quality of product is then diversified across a variety of different media and develops into a profitable industry, along with gaining a loyal audience and fans. ${ }^{356}$ For the product's receivers then, there emerges the task of identifying the circulating information and making attempts towards the restoration of completeness. ${ }^{357}$ Marvel Studios' handling of its transmedia narrative is what made its larger "MCU” unique.

The narrative continuity and seriality of the "MCU" makes this multi-franchise stand out within the crowded entertainment industry. At the end of Iron Man, Marvel Studios made a bold declaration about how its comics characters would be used in cinema henceforth. ${ }^{358}$ In a post-credits cameo of Iron Man Samuel L. Jackson appears as Colonel Nick Fury, Director of S.H.I.E.L.D. (Strategic Homeland Intervention, Enforcement and Logistics Division), setting the stage for the Avengers and with every following film in the production of the "MCU," Marvel Studios continued its tease of future movies, each post-credit scene contributing to the future narrative. ${ }^{359}$ In these isolated moments across discrete films, Marvel established narrative interrelationships

\footnotetext{
354 Ibid., 108.

${ }^{355}$ Ibid., 108.

${ }^{356}$ Elisavet Ioannidou, “Adapting Superhero Comics for the Big Screen: Subculture for the Masses," Adaptation 6.2

(Aug. 2013): 230-238, accessed February 20, 2014, 2.

${ }^{357}$ Ibid., 2.

358 Derek Johnson, "Cinematic destiny: Marvel Studios and the trade stories of industrial convergence," Cinema

Journal 52.1 (Fall 2012): 24, accessed February 21, 2014, 5.

${ }^{359}$ Ibid., 5.
} 
and limited serial progression across installments. ${ }^{360}$ In contrast, Marvel's earlier film releases made no attempt to draw links between heroes like the X-Men, Spider-Man, Hulk, and the Punisher. ${ }^{361}$ Promising that its releases would work in unison as the "MCU," Marvel presented individual films as mere episodes in a larger, cohesive work. ${ }^{362}$ In emphasizing connectivity between its films, Marvel relied on the aesthetics of "incompleteness" that are attributed to convergence culture. ${ }^{363}$ Dangling scenes and quick character teases in Marvel's films foster not just narrative expansion, but also an audience participation that extends the commercial viability of the films into new media markets beyond theatrical distribution. ${ }^{364}$ In other words, Marvel Studios' film narratives are crafted to make repeated consumption on DVD or digital download compulsory. The narrative links constituting the "MCU" encourage careful, repeated, often frame-byframe viewing, and audiences and fans are driven to purchase and consume all "MCU" products in order to attain narrative completion. ${ }^{365}$ Although these moments of interconnectivity constitute only a handful of scenes in otherwise self-contained films, when subjected to close visual scrutiny, those scenes offer a manufactured seriality. ${ }^{366}$ For example, producers used digital compositing to insert Captain America's shield into the background of Tony Stark's lab in the first Iron Man film and Tony would more explicitly interact with the shield as a prop in Iron Man 2. ${ }^{367}$ These scenes, whose significance is known to diehard comic book fans and only realized by the casual viewers

\footnotetext{
${ }^{360}$ Ibid., 6.

${ }^{361}$ Ibid., 6 .

${ }^{362}$ Ibid., 6.

${ }^{363}$ Ibid., 7.

${ }^{364}$ Ibid., 7.

${ }^{365}$ Ibid., 7.

${ }^{366}$ Ibid., 7.

${ }^{367}$ Ibid., 3.
} 
after watching later films, keep fans hooked and coming back to consume new films, television shows, comics etc.

Marvel Studios has developed a reputation as a studio at the top of the media franchising game, with its dominance of the San Diego Comic-Con International establishing its power in the entertainment industry. The San-Diego Comic-Con, established in 1970, has gained the reputation of being an entertainment Mecca for comic fans and pop culture enthusiasts, making it an ideal launch pad for Hollywood's projects. ${ }^{368}$ The summers of 2000 and 2001 were game changers regarding Hollywood's presence at Comic-Con, as the successes of $X$-Men and Spider-Man, served as examples of well-realized, faithfully executed comic adaptations that worked well as films and attracted an enormous box office gross. ${ }^{369}$ Comic-Con is a natural fit as Hollywood's testing ground; over 130,000 pop culture fanatics are present to market towards, while surrounded by press. ${ }^{370}$ The advent of social media accelerated and amplified the studios' intended result of creating word-of-mouth buzz from the "trusted," "authentic" and "authoritative" attendees of Comic-Con. ${ }^{371}$ In particular, Comic-Con's Hall H has become the grand stage for the promotion of the newest and hottest Hollywood transmedia franchises. ${ }^{372}$ However, Hall H does not guarantee immediate success. There have been many misfires and non-starters over the years, including Jon Favreau's Cowboys and Aliens (2011) and Michel Gondry's The Green Hornet (2011), or titles that received overwhelmingly positive reception and feedback in Hall $\mathrm{H}$ to go on an fail to

\footnotetext{
368 “About Comic-Con,” Comic-Con International: San Diego, 2015, accessed January 18, 2015, http://www.comiccon.org/about.

${ }^{369}$ Rob Salkowitz, Comic-Con and the Business of Pop Culture: What the World's Wildest Trade Show Can Tell Us About the Future of Entertainment, (New York: McGraw-Hill, 2012), 104-106.

${ }^{370}$ Ibid., 104.

371 Ibid., 104

${ }^{372}$ Ibid., 104.
} 
connect to a wider audience and bomb in the box office, such as Zack Snyder's Sucker Punch (2011) and Edgar Wright's Scott Pilgrim vs. The World (2011). ${ }^{373}$ The studios have stuck with the superhero formula, despite the hit or miss quality of the marketing payoff and the spotty track record of comics properties in both critical and commercial terms, because when superhero movies succeed, a franchise is born and that can spawn sequels with reduced marketing costs, and (theoretically) increasing audiences and profit. $^{374}$ Star power has always played a role in Comic-Con's off the charts attendance boom since the late 1990 s and it has contributed to the media-driven narrative that SanDiego is the place to be for the entertainment industry. ${ }^{375}$ It is often the only place where fans have the opportunity to meet their favorite stars and creators in person, establishing further (or at least the appearance of) intimacy and fan interaction. Marvel Studios has held panels and had their talent, crew and executives for the Iron Man trilogy, The Incredible Hulk, Thor, Captain America: The First Avenger, The Avengers, Captain America: The Winter Soldier, and Avengers: Age of Ultron attend Comic-Con and hold panels for their years of their respective releases. Marvel Studios' surprise announcement of the Avengers cast in 2010 set the bar for star appearances, only to be exceeded in 2013 when Tom Hiddleston, the actor who portrays the Avengers' villain, appeared in full Loki costume to promote Thor: The Dark World. ${ }^{376}$ Ultimately, a balance is key for telling satisfying stories across multiple media, while the success or failure of a transmedia project coming down to one brilliant decision (i.e. Tony Stark and

\footnotetext{
${ }^{373}$ Salkowitz, 104.

374 Ibid., 107.

375 Ibid., 104.

${ }^{376}$ Referring to Marvel Studios' star appearances see The Deadline Team, ““'MARVEL-OUS STAR WATTAGE: Actors Assemble For Comic-Con Panel Including 'The Avengers', 'Captain America', \& 'Thor'" and The Deadline Team, "Comic-Con: Loki Crashes Marvel Panel."
} 
RDJ) or a misguided one (making Frank Miller the director of The Spirit). ${ }^{377}$ Marvel Studios also employs cross-promotion to advertise the "MCU." An important transmedia narrative advantage Marvel Studios has over its competition is its Marvel "One-Shots," direct-to-video short films available on the Blu-rays and digital distribution of "MCU" films.

Marvel Studios' Marvel "One-Shots" occupy a unique place within the "MCU." These shorts serve as a self-contained story and provide more backstory to the world of the "MCU" and characters who would not warrant their own franchises. They also serve as a testing ground for new television projects for the company [See Appendix N]. ${ }^{378}$ Brad Winderbaum, co-producer of the "One-Shots" stated in 2011 the shorts were "a way for us to expand the Marvel Cinematic Universe and tell stories that live outside the plot of our features." 379 Marvel Studios co-president Louis D'Esposito has also stated "[not all Marvel characters can] be at the same level... so we introduce them [with a short] and [some] they take off." ${ }^{, 30}$ The development of a fan favorite character occurred with Agent Phil Coulson (Clark Gregg), a recurring minor character in "Phase One" of the "MCU." The Consultant, the first of Marvel "One-Shots," released in 2011, was Coulson's first solo outing and introduces the concept of "Level 7" clearance at S.H.I.E.L.D. that would play into the Marvel's Agents of S.H.I.E.L.D. series mythology, as well as Coulson's fellow SHIELD agent Sitwell (Maximiliano Hernandez), building out the world behind the superheroics unfolding in the main films. ${ }^{381}$ A Funny Thing

\footnotetext{
${ }^{377}$ Salkowitz, 112.

${ }^{378}$ Graeme McMillan, "From DVD to ABC: Why Marvel's 'One-Shots' Matter," The Hollywood Reporter, September 23, 2013, accessed March 20, 2014, http:/www.hollywoodreporter.com/live-feed/dvd-abc-why-marvels-one-634738, 1 .

${ }^{\frac{1}{379}}$ Ibid., 1.

${ }^{380}$ Ibid., 1 .

${ }^{381}$ Ibid., 2.
} 
Happened on the Way to Thor's Hammer (2011) further cemented Coulson's ability to be a lead role, sowing the seeds for Joss Whedon's development and creation of the television series Marvel's Agents of S.H.I.E.L.D, of which Coulson is the main character. ${ }^{382}$ Peggy Carter, Strategic Scientific Reserve agent and love-interest of Captain America, and yet another fan favorite, also featured in the "One-Shot" Agent Carter, which proved to be so popular that an Agent Carter miniseries featuring Peggy's missions and life after World War Two, was put into production. ${ }^{383}$ Shorts featuring Loki, Nick Fury and the Black Panther had been developed but were scrapped because the cost to produce them would have been too high to make them worth it, and in addition to releasing the shorts on Blu-ray, Marvel considered introducing them in theaters before a Marvel film release. ${ }^{384}$ The Marvel "One-Shots" also gave added value to purchasing the Blu-rays of the "MCU" films. Their addition stood out to fans and consumers, even amongst the general bonus features of behind-the-scenes information, interviews, and director commentaries, thus giving them more of a reason to purchase the Blu-rays. The Marvel "One-Shots" paved the way for the Marvel Studios to become involved in the television medium.

Marvel Studios utilizes cross-promotion through the American Broadcasting Company (ABC) television network, owned by the Walt Disney Company, to advertise and promote the "MCU." Cross-promotion occurs when major studios or conglomerates acquire television, cable networks, and new media series to advertise and promote their

\footnotetext{
${ }^{382}$ Ibid., 2

${ }^{383}$ Ibid., 2

${ }^{384}$ Marc Graser, "How Marvel is Turning to Short Films to Sell More DVDs, Blu-rays," Variety, July 23, 2013, accessed March 20, 2014, http://variety.com/2013/biz/news/how-marvel-is-turning-to-short-films-to-sell-more-dvdsblu-rays-1200566759/
} 
own feature films and television programs on other platforms within the conglomerate. ${ }^{385}$ Examples of this studio cross-promotion include Universal Studios, which owns the NBC network and MSNBC, and $20^{\text {th }}$ Century Fox, which owns the Fox Broadcasting Company and Fox News. ${ }^{386}$ Most producers generally agree that the single biggest factor affecting the success of a feature film upon release remains television advertising, so owning a broadcast or cable network, local stations, or an extensive internet presence gives a studio several advantages and places them in a good position in advertising. ${ }^{387}$ The studio can negotiate (essentially with itself) to buy and place advertising slots in the most desirable and highly catered programming segments, with the heaviest barrage slated in the week leading up to the release. ${ }^{388}$ The studio and network or networks can create and encourage, well in advance of a film's release, intertextual references to earlier films and their stars within existing television shows, as most studios have film and television production arms. ${ }^{389}$ The network can also produce and program "specials" timed to spike buzz during the week of the release of a film. ${ }^{390}$ Marvel Studios has smartly taken advantage of Disney's ownership of the ABC network. On March 18, 2014 the network aired its first specials "Marvel Studios: Assembling a Universe," examining the business and creative journeys behind Marvel Studios formation of the "MCU" while featuring sneak peeks of future films Captain America: The Winter Soldier, Guardians of the Galaxy, Avengers: Age of Ultron, and Ant-Man. ${ }^{391}$ ABC followed up with another special on November 4, 2014, "Marvel 75 Years: From Pulp To Pop!," which aired after

\footnotetext{
${ }^{385}$ Johnson, Media Franchising, 275.

386 Ibid., 275.

${ }^{387}$ Ibid., 275

${ }^{388}$ Ibid., 276.

${ }^{389}$ Ibid., 275.

${ }^{390}$ Ibid., 275

${ }^{391}$ Matt Strom, "Get Ready for Marvel Studios: Assembling a Universe With 3 New Clips," Marvel.com, March 17, 2014, accessed January 18, 2004, http://marvel.com/news/tv/22159/get ready for_marvel_studios assembling a universe with_3 new clips.
} 
that week's episode of Marvel's Agents of S.H.I.E.L.D. and was hosted by Emily Van Camp, lead actress of ABC's television melodrama Revenge and member of Captain America: The Winter Soldier's cast. ${ }^{392}$ The special debuted an extended official trailer of Avengers: Age of Ultron, after the trailer's unplanned leak on October 22 prior to the planned release of the trailer after that week's episode of Marvel's Agents of S.H.I.E.L.D. ${ }^{393}$ The process of cross-promotion shifts much of a studio's risk and costs of a large film marketing campaign onto the shoulders of affiliate networks and stations within the conglomerate. ${ }^{394}$ The conglomerate's broadcast and cable networks also initiate programming and promotional budgets as part of their own internal programming and promotional budgets, again taking risk away from the studios. ${ }^{395}$ Marvel Studios, through the Walt Disney Company, utilizes the ABC network (as Disney owns both Marvel Studios and ABC). Television has become a crucial entertainment medium for a franchise to employ, especially for the "MCU."

Television has become an integral component of transmedia storytelling and the maintenance of franchises. With the increasing integration of new media technologies into practices in TV production and promotion, television has become a crucial aspect of transmedia and is the entertainment medium most often utilized to enrich and bring context to a franchise's universe. ${ }^{396}$ Transmedia storytelling is the latest way to imagine and create a TV show; the story has to be complex with a compelling seriality and mythology, engaging for fans to dive emotionally and intellectually into, and innovative

\footnotetext{
392 Tyler McCarthy, “'Avengers: Age Of Ultron' Trailer Breaks Records, Marvel Promises More Footage During 'Agents Of SHIELD,"' International Business Times, October 26, 2014, accessed January 18, 2015, http://www.ibtimes.com/avengers-age-ultron-trailer-breaks-records-marvel-promises-more-footage-during-agents1714697.

$\overline{393}$ Ibid., 1.

394 Johnson, Media Franchising, 275.

395 Ibid., 276

${ }^{396}$ Melanie Bourdaa, “'Following the Pattern': The Creation of an Encyclopaedic Universe with Transmedia Storytelling,” Adaptation 6.2 (Aug. 2013): 202, accessed February 28, 2014, 12.
} 
in its narration and in the way it makes fans interact. ${ }^{397}$ In the case of Marvel Studios' television shows, along with telling their own stories, they serve to expand and maintain the "MCU" brand. Branding has emerged as a central part of the film and television industries in the age of digital convergence and as one of the chief means through which marketing identity is engineered. ${ }^{398}$ It refers not only to product or company names, titles, or the trademark designation created by marketers and advertisers, but a projected image of a more holistic identity to viewers and consumers. ${ }^{399}$ Through branding, a product aims to achieve a set of recurrent goals and market ideals: a widely and recognizable image, a distinct personality among competitors, a consistency wherever the brand is encountered, and a confidence in the quality of the brand. ${ }^{400}$ With Marvel Studios' television shows, they theoretically have a built in audience consisting of the "MCU" film fans. Television is an important pillar of the "MCU."

Marvel Studios' premier television show Marvel's Agents of S.H.I.E.L.D. (2013), Marvel's Agent Carter (2015) is cautionary tale about how to adapt a franchise to for television. Marvel's Agents of S.H.I.E.L.D., executive produced and co-created by Avengers director Joss Whedon, his brother Jed Whedon and Jed's wife Maurissa Tancharoen, was Marvel Studios first foray into television, with mixed results. ${ }^{401}$ Marvel's Agents of S.H.I.E.L.D. got a huge audience of 12.12 million viewers for its pilot, but half of those viewers left after the show turned out to be not enough like the

\footnotetext{
${ }^{397}$ Ibid., 12.

${ }^{398}$ John Thornton Caldwell, Production Culture: Industrial Reflexivity and Critical Practice in Film and Television (North Carolina: Duke University Press, 2008), 245.

399 Ibid., 245

${ }^{400}$ Ibid., 245.

${ }^{401}$ Referring to Marvel's Agents of S.H.I.E.L.D's creation see Marvel.com "Marvel's Agents of S.H.I.E.L.D," and Jaime Weinman, "Why is it so hard to make a successful TV spinoff of a hit film?," 2.
} 
movies. ${ }^{402}$ The show's pilot was successful but was unable to successfully blend the unique cinematic superheroics with the routine of network television, and came off as generic and mundane to audiences, leading to declining ratings with each successive episode. However, the show did succeed as a transmedia narrative. Marvel's Agents of S.H.I.E.L.D. had tie-in episodes to Thor: The Dark World and Captain America: the Winter Soldier in its first season, and gave backstory and focus to what was occurring in the "MCU" world outside of the main films, while still remaining connected to them; the virus Extremis featured in Iron Man 3 and the female warrior Sif, a supporting character from Thor, were part of important narrative arcs in the first season. The show also further dived into the comic mythology, featuring Marvel comics' characters such as the cyborg assassin Deathlok, and the Asgardian sorceress Amora in its first season, and the hero Bobbi Morse, a.k.a Mockingbird, in the second season. The show eventually gained new life as the characters faced irreparable consequences after the shocking aftermath of Captain America: The Winter Soldier, in the latter half of its first season and with a much better reviewed second season, which laid the groundwork for the future Inhumans (2019) film, but its ratings remain low [See Appendix L]. The lesson from Marvel's Agents of S.H.I.E.L.D. 's stumble is that while superhero films can dominate the box office, it doesn't guarantee television success. ${ }^{403}$ However, Marvel isn't the only successful movie producer to prove mortal and fallible when it comes to the younger medium. ${ }^{404}$ Star Wars and Indiana Jones are two of the best film franchises in the world, but their live-action TV spinoffs, The Young Indiana Jones Chronicles (1994-1996) and

\footnotetext{
${ }^{402}$ Referring to Marvel's Agents of S.H.I.E.L.D's average success see Wikipedia “Agents of S.H.I.E.L.D. (season 1) and Jaimie Weinman, "Why is it so hard to make a successful TV spinoff of a hit film?," 2.

${ }^{403}$ Ibid., 1.

${ }^{404}$ Ibid., 1
} 
the infamous Star Wars Holiday Special (1978) crashed and burned. ${ }^{405}$ The prequel spinoff of James Cameron's Terminator films, Terminator: The Sarah Conner Chronicles (2008-2009), was also short lived. ${ }^{406}$ The issue regarding the lack of television spinoffs is due to studios saving their important franchises for the films because there is more money in film than television, and the difference in narrative structure: what's suited to a film, or even a series of films, doesn't work so well for a show that has to develop with thirteen to twenty-two episodes a year. ${ }^{407}$ The name recognition that comes with a movie tie-in can actually be a negative: the more people know the original movies, the more they'll be disappointed with the television version. ${ }^{408}$ The core audience (the fans of the films) will tune in for the first episode, but they can be lost quickly if their attention is not kept. ${ }^{409}$ Furthermore, fans are particularly hard to please when they're used to better production values than a television show, even a relatively expensive one, can ever deliver. ${ }^{410}$ Rather than going big, and then busting, television appears to be the best medium to introduce and develop the minor characters of a transmedia franchise, a course correction Marvel Studios took to heart.

Despite its missteps with Marvel's Agents of S.H.I.E.L.D., Marvel Studios' following television series, Marvel's Agent Carter (2015) and its future series with ondemand streaming service Netflix demonstrate the future growth of the "MCU" outside of film. Agent Carter, having premiered on January 6, 2015, received strong critical reviews and was received with more excitement and warmth that Marvel's Agents of S.H.I.E.L.D. [See Appendix N]. Marvel Studios took the criticism of Marvel's Agents of

\footnotetext{
${ }^{405}$ Ibid., 1.

${ }^{406}$ Ibid., 1.

${ }^{407}$ Ibid., 2.

${ }^{408}$ Ibid., 2.

${ }^{409}$ Ibid., 1 .

${ }^{410}$ Ibid., 2
} 
S.H.I.E.L.D. to heart and focused on crafting a contained story within Marvel's Agent

Carter's eight episodes, and embracing the pulp adventure genre that characterized 1940s entertainment. In November 2014, it was announced that Disney and Marvel Studios had partnered with Netflix to produce four superhero series (Daredevil, Jessica Jones, Iron Fist and Luke Cage), whose leads ultimately would team up for a miniseries, The Defenders. ${ }^{411}$ These characters are less tiered in the comics and aren't considered popular enough to warrant big-budget films, but if enough of Netflix's forty million subscribers worldwide take to them, they could be. ${ }^{412}$ As Tim Beyers, from the multimedia financial-services company The Motley Crew, notes "the Netflix effect [of popularity] is real and an attractive draw for studios...known characters offer the most upside.... unknowns cost less to produce and, for Netflix, less to acquire." ${ }^{413}$ Another upside is that newer and larger projects could develop from the limited series, such as solo feature films and appearances in future "MCU" films and television fan favorite characters equivalent to Tony Stark/Iron Man could be uncovered, adding to the shows' popularity. ${ }^{414}$ At the same time, Netflix benefits from the additional original programming and the series will also prove more cost effective than the Marvel Studios shows, which are pricier shows for $\mathrm{ABC}$ and require bigger budgets for visual and special effects. ${ }^{415}$ Marvel Studios also uses comics and video games to expand the "MCU's" transmedia franchise.

The separate, yet distinct, mediums of comics and video games contribute to the

\footnotetext{
${ }^{411}$ Paul Bond, “Analysts Split on Netflix Deal With Marvel For 'Defenders'," The Hollywood Reporter, November 13, 2013, accessed April 2, 2014, http://www.hollywoodreporter.com/news/netflix-marvels-defenders-analysts-split655382,1 .

412 Ibid., 1.

413 Ibid., 1

${ }^{414}$ Ibid., 1 .

${ }^{415}$ Ibid., 1.
} 
transmedia narrative of the "MCU." The "MCU" uses the comics as tie-in materials when promoting its films and television series. The role of "tie-in" comics is to give further backstory to events occurring within the "MCU" films and television series, and stir up anticipation for future projects. For example, Thor: The Dark World Prelude addresses the return of Thor and Loki to Asgard after Loki's defeat in the Avengers, and how Thor restored inter-planetary travel by using the Tessaract to repair the Bifrost [See Appendix O]. Like the comics, each film in the "MCU," with the exception of the Avengers, has a licensed tie-in video game. Rather than license their video games out to different production companies, Marvel awarded a single master license to Sega for all game software related to the Iron Man, Captain America, and Hulk movies, reflecting its own centralized reorganization of film production. ${ }^{416}$ Although Marvel could not directly control production of video games and other licensed merchandise at the same time that it financed its own film operations, it similarly consolidated its licenses, and brought further continuity to the licensing program. ${ }^{417}$ Justin Lambros, the Marvel Studios executive who oversaw the production of licensed video games of Marvel characters, stated "[the production company] take the lead from where the film is going, then take stuff from the comics for the game and filter it through the film." ${ }^{418}$ The priority of the "MCU" video games was ensuring conformity to emerging film styles and strategies, emphasizing how Marvel's filmmaking operations trumped anything developing in other markets. ${ }^{419}$

\footnotetext{
${ }^{416}$ Johnson, Media Franchising, 97.

417 Ibid., 97.

418 Ibid., 97.

419 Ibid., 97.
} 
Marvel allowed its master game license with Sega to expire in 2012, with the Paris based video game production company Gameloft, producing the subsequent "MCU" video games [See Appendix P]. Gameloft has ties to Disney, having produced video games for Disney properties such as Cars and Monsters University, which suggests Marvel is looking to eventually have future video games produced in-house by Disney, the first of which was Guardians of the Galaxy: The Universal Weapon, produced by the Disney Interactive Media group [See Appendix P]. Each disparate entertainment medium whether comics, video games, or television, plays an essential part in the sustained popularity and prosperity of the "MCU."

The success of the Marvel Studios' "MCU" illustrates the influence and power of convergence culture. The transmedia elements that constitute the "MCU," from the tie-in comics for each individual film to the Marvel One-Shots, some of which developed into Marvel Studios' television shows Marvel's Agents of S.H.I.E.L.D. and Marvel's Agent Carter, enable its constantly growing and expanding universe, and attract old and new fans who then explore the other products within the franchise. Marvel Studios' accomplishments with the "MCU" has led the other studios in Hollywood who hold the rights to superhero characters to try and emulate their financial and critical success. 


\section{CHAPTER FOUR}

\section{"GREEN WITH ENVY (AND CASH)": THE FUTURE OF SUPERHERO FRANCHISING IN HOLLYWOOD}

Marvel Studios" "Marvel Cinematic Universe" [hereafter referred to as the "MCU"] has had an enormous influence on superhero franchising within Hollywood. By 2012, after the juggernaut success of the Avengers, $20^{\text {th }}$ Century Fox Pictures and Sony Pictures, the studios that still retained the rights to certain Marvel Comics characters, and Warner Bros. Pictures, who held the rights to all of DC Comics' characters, began to plan how to emulate Marvel Studios' success. Each studio has attempted to create a "megafranchise" in the style of the "MCU" around their superhero characters, hoping to attract audiences and revenue with the same characters across multiple sequels and spinoffs set within a self-contained cinematic universe. The "MCU" definitively altered the production and franchising of superhero films, and has become the gold standard for imitators.

Hollywood's studios have embraced the franchise, and the blockbuster films that comprise them, stuffed with sumptuous visual effects and A-list stars, with the desperation indicative of a volatile industry. ${ }^{420}$ This recent shift towards a franchiseminded mentality is due to a variety of factors. At first glance, the "blockbuster strategy" employed by the studios, where a studio puts itself in a position where their overall performance and survival rests on a few big films each year, and lets spending on those films reach levels that make recovering costs appear almost impossible, seems

\footnotetext{
${ }^{420}$ Anita Elberse, Blockbusters: Hit-making, Risk-taking, and the Big Business of Entertainment (New York: Henry Holt and Co., 2013), 3.
} 
illogical. ${ }^{421}$ In fact, however, the "blockbuster strategy," in key respects, works. Warner Bros.' 2010 film slate is an example of the success of the "blockbuster strategy. ${ }^{422}$ Warner Bros. released twenty-two films in 2010, spending about $\$ 1.5$ billion in production costs and upward of $\$ 700$ million on advertising and promotion domestically. ${ }^{423}$ The studio spent a third of its 2010 production budget on its three biggest titles: \$250 million on Harry Potter and the Deathly Hallows: Part 1, \$175 million on Inception and \$125 million on Clash of the Titans. Big films such as these often feature not only A-list talent, but also elaborate visual effects, all of which drive up the pictures' costs. ${ }^{424}$ However, Warner Bros.' results lived up to their prediction that their films with the highest costs would also bring the highest revenues and profits. ${ }^{425}$ Harry Potter and the Deathly Hallows: Part One, Inception, and Clash of the Titans accounted for only a third of the total production budget, but were responsible for over $40 \%$ of the domestic and $50 \%$ of the worldwide box-office revenues generated that year. ${ }^{426}$ This jackpot of revenue is the reason why the leaders of film studios, and of other sectors of the entertainment industry thrive on making huge investments to acquire, develop and market concepts with strong hit potential, and they bank on the sales of those to make up for the middling performance of their other content. ${ }^{427}$ The decrease in the cost of promotion and advertising is another factor in the studios' wholehearted support of blockbuster/franchise films.

\footnotetext{
${ }^{421}$ Ibid., 3.

${ }^{422}$ Ibid., 3.

${ }^{423}$ Ibid., 19.

${ }^{424}$ Ibid., 19 .

${ }^{425}$ Ibid., $19-20$.

${ }^{426}$ Ibid., 20.

${ }^{427}$ Ibid., 3.
} 
Advertising is another cost attached to a film, often unreported to the press, which can be partially negated by blockbuster/franchise films. The success of the "blockbuster strategy" is even more apparent when marketing costs are included, since making bigger films results in advertising efficiencies. ${ }^{428}$ Put bluntly, making a less expensive, non-franchise film is more expensive to studios because it costs more to raise awareness of the film to the public and advertise nationally it through traditional media. In comparison, marketing a blockbuster or franchise film will not require the same amount of money to advertise (unless a studio pushes for spectacle) due to the public knowing and having pre-awareness of such a blockbuster film/franchise. ${ }^{429}$ Alan Horn, current chairman of Walt Disney Studios and former president and COO of Warner Bros., explains that "the advertising expenditures for a movie that costs $\$ 150$ million to make are not twice those for a $\$ 75$ million movie, even if you saturate the market... you need a certain amount [of money] to make sure you can support [a] film nationally, just to tell audiences you are out there." ${ }^{430}$ Betting heavily on likely blockbusters and spending considerably less on smaller films is the surest way to lasting success in the film industry, especially in the face of the fickle taste of consumers and complexities of a production process that often involves hundreds of people. ${ }^{431}$ Studios would be taking a greater risk if they make more films with lower production budgets. For a larger studio, smaller movies could in a typical year actually lose the studio more money than they bring in; even if some smaller investments do make money, a dollar spend on a bigbudget film will average a much higher profit. ${ }^{432}$ The studios take their chances by

\footnotetext{
428 Ibid., 24.

${ }^{429}$ Ibid., 24.

430 Ibid., 24.

${ }^{431}$ Ibid., 4, 18-19.

432 Ibid., 27.
} 
investing heavily in the development, supporting them with promotional spending, often well in advance of their release into the marketplace and distributing them as widely as possible. ${ }^{433}$ However, blockbuster strategies are not free of risk; even the biggest productions supported by the highest advertising budgets can, and sometimes will, fail to create a splash in the market, as did John Carter (2012) and The Lone Ranger (2013). ${ }^{434}$

Another factor as to why the studios rely so heavily on the revenues of their blockbuster/franchise films is the collapse of the DVD market. In the late 1990s and early 2000s, DVDs famously provided the film industry with significant new forms of revenue. $^{435}$ As numerous critics have noted, many Hollywood films only began to see profits after their DVD release, prompting some to suggest that the theatrical release is merely a means of promoting the DVD, a loss leader with an eye toward the home market. ${ }^{436}$ Media studies scholar John Thornton Caldwell went so far as to say that the DVD experience is "the primary consumer product." 437 Entertainment reporter Edward Jay Epstein also noted that in 2002, some 50 million Americans, more than twice the weekly movie audience, went to one of the country's more than thirty thousand local video stores to rent a movie, spending some \$24 billion (19 Tryon), approximately four times what they spent of movie tickets. ${ }^{438}$ DVDs continued to provide a crucial revenue stream with consumer spending on sell-through DVDs (the percentage of units shipped that were actually sold) holding relatively steady at around $\$ 16$ billion per year in 2006

\footnotetext{
${ }^{433}$ Ibid., 4.

${ }^{434}$ Referring to Disney's blockbuster failures see Anita Elberse, Blockbusters: Hit-making, Risk-taking, and the Big Business of Entertainment (New York: Henry Holt and Co., 2013), 4 and Jaime Weinman, "The decline of Disney," 1.

${ }^{435}$ Chuck Tyron. Reinventing Cinema: Movies in the Age of Media Convergence (New Jersey: Rutgers University Press, 2009), 19.

${ }^{436}$ Ibid., 19.

${ }^{437}$ Ibid., 19.

438 Ibid., 19.
} 
and $2007 .^{439}$ However, since then these numbers have been enormously offset by the rise of digital cable, video-on demand serves such as Netflix and Amazon Prime, and digital distribution via services such as Apple's iTunes, leaving video rental chains such as Blockbuster in the dust and bankrupt. ${ }^{440}$ The DVD market was critical to the studios, because the historical movie business, with all of the cumulative Hollywood studios, runs at about a $10 \%$ profit margin. ${ }^{441}$ For every billion dollars spent in revenue, a hundred million dollars is received in profit. ${ }^{442}$ The DVD business represented $50 \%$ of the studios' profits, with the consequence that the decline of that business brought down their entire profit margin to only around 5-6\%. ${ }^{443}$ The loss of profit from the DVD market halved the studios' profit margin, and at best cut into their profit by half for new movies, which has already been put under further strain with the rise of piracy, VOD and cable. ${ }^{444}$ The international market will still grow but the DVD sell-through business is not coming back. $^{445}$ Consumers will watch their movies on Netflix, iTunes, Amazon et al before they will purchase a DVD. The old profit margin has gone the way of old media. ${ }^{446}$ In response, the Hollywood studios have turned to the rapidly growing global box office to maintain their profits and revenues.

The global box office has become a beacon of hope for Hollywood, especially in regards to blockbuster films/franchises. With the growing importance of global markets, the relevance of blockbuster films/franchises will only increase. ${ }^{447}$ As Alan Horn,

\footnotetext{
439 Ibid., 20.

${ }^{440}$ Ibid., 20.

${ }^{441}$ Lynda Obst, Sleepless in Hollywood: Tales from the New Abnormal in the Movie Business, (New York: Simon \& Schuster, 2013), 40.

442 Ibid., 40-41

443 Ibid., 41.

444 Ibid., 41.

445 Ibid., 42.

446 Ibid., 42.

447 Ibid., 24.
} 
chairman of Walt Disney Studios, remarked in 2012, "international box office results are especially strong for event movies...that's where the real growth is....by 2016 the international box office is projected to be \$27 billion, much larger than the [2012] domestic box office at a projected $\$ 11$ billion. ${ }^{, 48}$ The key concern is with theatrical markets that are said to be "under-screened," where in comparison to the United States, there are relatively fewer theatres serving moviegoers. Such markets, which include China and India, tend to be more selective with regard to the type of films that do well with audiences. ${ }^{449}$ Most desirable are what are called four-quadrant films (films that appeal to males and females both over and under twenty-five) with familiar stars or characters. ${ }^{450}$ While there are certain A-list stars (ie. Tom Cruise, Angelina Jolie etc.) whose names have become genuine international box office draws, what draws the vast international audiences is a well-known and popular brand, such as Harry Potter or Transformers. ${ }^{451}$ The apathetic attitude of the international audiences towards stars work in the studios' favor; they can then invent stars for blockbuster films/franchises, pay them less up front, and put them under contract for infinite options for sequels, as Chris Hemsworth did for Thor. ${ }^{452}$ This results when the film/franchise is more important than the star (ie. James Bond), while giving the studios enough room to remake films; if a studio remakes a franchise, they do not need to increase the salary of the lead if the star is an unknown. ${ }^{453}$ The franchise is the star for a film that costs a fortune; the benefit for the star is that if the movie does well, and has large international numbers, they have enough

\footnotetext{
${ }^{448}$ Ibid., 24.

${ }^{449}$ Ibid., 24

${ }^{450}$ Ibid., 18

${ }^{451}$ Ibid., 18.

452 Ibid., $18-19$.

${ }^{453}$ Ibid., 19.
} 
influence to make other films they are passionate about. ${ }^{454}$ Marvel Studios' success is tied to how it has differentiated itself from other franchises, and how it has cultivated its "Marvel Studios" brand, and essential in this regard have been films that imply the fourquadrant formula.

Marvel Studios' brand is not only its films or characters, although they are essential to the brand, but the studio itself. Marvel Studios is in the business of making superhero movies and only superhero movies; they only develop and produce two to three films a year in comparison to Warner Bros., who releases all kinds of movies, with superhero films being just one small portion of their annual slate of films. ${ }^{455}$ Thus, the studio would naturally be able to spend more time developing a much larger slate of distinct franchises, and give more individual attention to each movie. Marvel Studios developed a detailed plan, in multiple phases, with the most effective part of their plan being branding the name "Marvel" so that audiences worldwide now respond to that brand in a way almost no other studio or production company can match. ${ }^{456}$ The name "Marvel" has become synonymous with high-quality, successful superhero movies, and people everywhere, not just comic book fans, but also the mainstream public, recognize the brand name when they see it and know what to expect. ${ }^{457}$ Only Disney and Lucasfilm (now owned by Disney) achieved that kind of distinct name recognition for their studio when it comes to content branding. ${ }^{458}$ In most comparable cases, it is a big director or a movie star whose name brings the brand recognition, or the particular franchise itself, but

\footnotetext{
454 Ibid., 19.

455 Mark Hughes, "Why Marvel Is Defining The Modern Superhero Film Genre," Forbes, October 10, 2013, accessed February 20, 2014, http://www.forbes.com/sites/markhughes/2013/10/29/why-marvel-is-defining-the-modernsuperhero-film-genre/, 3 .

${ }^{456}$ Ibid., 3.

${ }^{457}$ Ibid., 3 .

${ }^{458}$ Ibid., 3
} 
with Marvel, like with Disney or Lucasfilm, the name alone brings with it the same sort of recognition and familiarity. ${ }^{459}$ The result from this is not only does each new Marvel Studios film have the increased likelihood of becoming a box office blockbuster, but that their future franchises don't have to have name recognition for the characters because the Marvel branding alone brings instant top-tier recognition to even the least-known characters. ${ }^{460}$ Marvel Studios' smash success Guardians of the Galaxy is proof that their branding works. The implications for this situation are enormous, especially in comparison to Warmer Bros.' development of its DC Comics franchises, which seem focus on how bankable each individual character is, and remain thus far reluctant to take risks on lesser-known commodities. ${ }^{461}$ Marvel Studios' branding success is what has enabled it to position itself as a studio with agency within Hollywood, and to place emphasis and importance on its characters.

Despite being bought by the Walt Disney Company in 2009, Marvel Studios still retains agency and control of its productions and characters. The significance of Marvel Studios establishing the Merrill Lynch deal in 2005 was that it granted the studio creative control and agency over its production. ${ }^{462}$ By transforming from a licensor that sold studios the right to create and profit from their comic book characters to a production entity that maintained control and adopted the risks of film development itself, Marvel Studios carved a space within Hollywood for an external production studio with (at first) limited film expertise. ${ }^{463}$ Through cultural convergence, Marvel Studios developed a unified brand for itself and its films while at the same time devising diverse approaches

\footnotetext{
${ }^{459}$ Ibid., 4.

${ }^{460}$ Ibid., 4.

${ }^{461}$ Ibid., 4 .

${ }^{462}$ Derek Johnson, "Cinematic Destiny: Marvel Studios and the trade stories of industrial convergence," Cinema Journal 52.1 (Fall 2012): 24, accessed February 21, 2014, 9.

${ }^{463}$ Ibid., 9.
} 
to mobilizing the characters that made up that brand. ${ }^{464}$ Ultimately, the studio recasts the production of comic book films and video games, not in terms of specific media platforms, but instead in terms of the iconic characters Marvel had on offer, emphasizing a special relationship with its consumers. ${ }^{465}$ Former Marvel Studios chairman and CEO David Maisel perpetuated this narrative when he told the Hollywood Reporter upon the release of Iron Man in May 2008, "we are in the Iron Man business ... so whether it is a major motion picture or a video game, we have somewhat of an obligation to our fans and the consumer to stay involved with the creative process. ${ }^{466}$ Along with being a strong supporter of its comics characters, Marvel Studios established itself as a stronghold of creativity within Hollywood, as well as a strong supporter of its comics characters.

Marvel Studios has cultivated a reputation as a creative bastion as part of its reputation and brand. Marvel Studios has cultivated an image of a "creative savior" to its superhero characters. Its executives have deliberately promoted their corporate control and managerial expertise in direct opposition to creative processes in the film industry, to which it has attributed any and all past critical or commercial failures. ${ }^{467}$ One example of such promotion is a comment Avi Arad made shortly after the Merrill Lynch deal closed in 2005: "we've had one bad movie, Elektra [produced by 20th Century Fox], and it was bad because we did not have creative control. That won't happen again.. ${ }^{468}$ Marvel's ability to manage the creative enterprise of filmmaking was framed as a necessity for commercial and critical success, rather than as meddling by an outside executive office

\footnotetext{
${ }^{464}$ Ibid., 8.

465 Ibid., 16.

466 Ibid., 16.

467 Ibid., 17.

468 Ibid., 17.
} 
without filmmaking expertise. ${ }^{469}$ These self-reflexive discourses cast Marvel Studios in a parental role vis-à-vis their films and their place in convergence culture, framing their "parental rights" as a function of corporate management as much as creativity, positioning and rebranding Marvel as the corporate entity best suited to the job of overseeing converged film production. ${ }^{470}$ Marvel Studio's relationship with comic book fans is another crucial factor behind their reputation.

Cultivating a legitimate reputation as "fans" of the original comic source material is another narrative employed by Marvel Studios. The studio characterized Marvel's external expertise in managing comic book culture as a boon to the specific needs of the film industry by playing up affinities between key managers and its consumer base of purported value. $^{471}$ Marvel Studios executives such as David Maisel, Avi Arad and Kevin Feige positioned themselves as "fans," and claimed a unique, insider perspective into the tastes of a "fanboy" audience of adult and adolescent males targeted by Hollywood blockbusters. ${ }^{472}$ Feige, for example, claimed insight into fanboy skepticism, and by self-identifying with this fan position in his interviews, he not only called into question the Hollywood studios' ability to handle the material, but also built up his own authority to handle the material. ${ }^{473}$ These self-reflective discourses were supported by trade publications fed by effusive praise from reporters such as Borys Kit in the Hollywood Reporter proclaiming, "Kevin Feige's love of comic books goes back to childhood. $^{474}$ Now, as the man who produces all of Marvel's movies, Feige is attempting to do what only a kid might dream up: create multiple movie franchises that tie in to one

\footnotetext{
${ }^{469}$ Ibid., 17.

${ }^{470}$ Ibid., 17.

471 Ibid., 19.

472 Ibid., 19.

473 Ibid., 19.

474 Ibid., 19.
} 
cohesive universe." "475 Marvel Studios' carefully constructed persona of "fanboy" credibility gained the comics' fans seal of approval, who in turn reassured the public that Marvel Studios is the "real deal." 476

Marvel Studios has reinforced the "Marvel brand" in its films, and its "MCU" library can be broken down into three distinct phases. The studios' future films, in particular the films comprising "Phase Two," demonstrates its confidence in its brand. Marvel Studios' "Phase One" films consisted of Iron Man (2008), The Incredible Hulk (2008), Iron Man 2 (2010), Thor (2011), Captain America: The First Avenger (2011), and the Avengers (2012), establishing the foundation for the future phases to come. Marvel Studios' final films for "Phase Two" of the "MCU" are the Avengers sequel, Avengers: Age of Ultron (2014) and Ant-Man (2015). Avengers: Age of Ultron, directed by Joss Whedon and to be released May 1, 2015, features the returning Avengers cast teaming up once again to fight Ultron, an alien artificial intelligence bent on destroying humanity in order to create peace. ${ }^{477}$ The film, as the sequel to the third biggest domestic and worldwide grossing film of all time, had been described by the cast as the biggest Marvel Studios film to date, with Joss Whedon stating the Avengers sequel will be "more personal, more painful."${ }^{, 478}$ The film was surrounded by controversy after its first official trailer leaked a week early in October 22, 2014. ${ }^{479}$ Marvel Studios took swift action against the leak, subpoenaing Google in the hopes of obtaining the identity of the

\footnotetext{
475 Ibid., 19.

476 Ibid., 19.

477 Brian Feldman, "Here Is Everything We Know About The Avengers 2: Age of Ultron," Vulture, August 19, 2014, accessed August 28, 2014, http://www.vulture.com/2014/08/everything-we-know-about-the-avengers-2-age-ofultron.html, 1 .

${ }^{478}$ Ibid., 1 .

${ }^{479}$ Eriq Gardner, "Marvel Seeks to Subpoena Google Over 'Avengers: Age of Ultron' Leak (Exclusive)," The Hollywood Reporter, November 6, 2014, accessed November 10, 2014, http://www.hollywoodreporter.com/thresq/marvel-seeks-subpoena-google-avengers-747024, 1.
} 
leaker. ${ }^{480}$ The studios' actions may seem overzealous to some, but the leaks of blockbuster films such as X-Men Origins: Wolverine and Expendables 3 prior to their release illustrate a real threat of online piracy to meticulously planned blockbuster films whose box office is crucial to a studio's bottom line. ${ }^{481}$ Marvel Studios' Ant-Man, to be released July 17, 2015, starring Paul Rudd, Michael Douglas and Evangeline Lilly, will conclude "Phase Two" of the "MCU." 482 The film was to be directed by Edgar Wright (Shaun of the Dean, Hot Fuzz, Scott Pilgrim vs. The World), but Wright dropped out of the project in May 2014 only months before production was supposed to start, despite being attached to the project for over eight years. ${ }^{483}$ Wright supposedly left over "creative differences," due to him wanting Ant-Man to be more in line as a stand-alone film, while Marvel Studios wanted the film to fit within the greater "MCU." ${ }^{\text {"484 }}$ Despite the initial drama, Ant-Man successfully began production, and Peyton Reed (Bring It On, Yes Man) was hired as the film's new director and Adam McKay (Anchorman, The Other Guys) and Ant-Man star Paul Rudd rewrote Wright's screenplay. ${ }^{485}$ Marvel's 'Phase Three" films and its forthcoming television series sit on the shoulders of the films in "Phases One" and "Two" and are a culmination of the studio's long-term planning. Marvel Studios" "Phase Three" films, and its Netflix television series solidifies Marvel Studios' dominance in the superhero genre. On October 28, 2014, Marvel

\footnotetext{
${ }^{480}$ Ibid., 1.

${ }^{481}$ Ibid., 1

482 Jason Concepcion, “A Movie-by-Movie Guide to Marvel's Phase 3, From Civil War to Infinity Wars," Grantland, October 29, 2014, accessed November 16, 2014. http://grantland.com/hollywood-prospectus/a-movie-by-movie-guideto-marvels-phase-3-from-civil-war-to-infinity-wars/, 2.

${ }^{483}$ Rodrigo Perez, "Why Edgar Wright Left Marvel's 'Ant-Man': Analysis \& The Screenplay Rumors," The Playlist, May 24, 2014, accessed November 13, 2014, http://blogs.indiewire.com/theplaylist/why-edgar-wright-left-marvels-antman-analysis-the-screenplay-rumors-20140524, 1.

${ }^{484}$ Ibid., 3.

${ }^{485}$ Kevin Jagernauth, "Comic Roundup: Adam McKay May Direct A Marvel Movie, Quicksilver To Appear In 'XMen: Apocalypse’ \& More,” Playlist, October 24, 2014. Accessed October 15, 2014.

http://blogs.indiewire.com/theplaylist/comics-roundup-adam-mckay-may-direct-a-marvel-movie-quicksilver-to-appearin-X-men-apocalypse-and-more-20141024, 1.
} 
Studios announced the film slate of "Phase Three" of the "MCU," consisting of Captain America: Civil War (May 16, 2016), Doctor Strange (November 4, 2016), Guardians of the Galaxy 2 (May 5, 2017), the untitled Spider-Man film (July 28, 2017), Thor:

Ragnarok (November 3, 2017), Black Panther (July 6, 2018), Captain Marvel

(November 2, 2018), Inhumans (July 12, 2019) and Avengers: Infinity Wars Part 1 (May 4, 2018) and Part 2 (May 3, 2019). ${ }^{486}$ This announcement was momentous because it confirmed the "MCU" 's buildup to an endgame involving the classic Marvel Comics supervillain Thanos and the all powerful Infinity Gauntlet, a conflict whose story has been subtly established throughout Marvel Studios" "Phase One" and "Phase Two" films. Dedicated comic fans rejoiced at an adaptation of the 2006 Marvel Comics megacrossover event Civil War with Captain America: Civil War, while casual and committed fans of the "MCU" alike celebrated the announcement of Black Panther and Captain Marvel. ${ }^{487}$ Marvel Studios has been criticized for its lack of persons-of-color and female superheroes, with fans clamoring for Black Panther and Black Widow films. ${ }^{488}$ Although the majority of Marvel Studios' superheroes remain male and Caucasian, the announcement of Black Panther, starring the up-and-coming Chadwick Boseman (42, Get $O n U p$ ), and Captain Marvel, whose comic book series featuring Air Force pilot turned superhero Carol Danvers was restarted in 2012 to much critical and popular acclaim, are a good start to further superhero diversity in film. ${ }^{489}$ Along with its film slate, the first of Marvel's Netflix television series, Daredevil starring Charlie Cox (Boardwalk Empire, Stardust), is to be released in April 10, 2015, with Krysten Ritter

\footnotetext{
${ }^{486}$ Concepcion, "Movie-by-Movie," 1-13.

${ }^{487}$ Ibid., 3-5.

${ }^{488}$ Andrew Wheeler, "Why Marvel Studios Succeeds (And How It Will Fail If It Doesn't Diversify)," Comics Alliance, August 6, 2014, accessed August 28, 2014, http://comicsalliance.com/marvel-studios-success-marvel-moviesdiversity/, 4-6.

${ }^{489}$ Concepcion, "Movie-by-Movie," 9-11.
} 
(Breaking Bad, Don't Trust the B---- in Apartment 23) and Mike Colter (The Good Wife) and the leads for A.K.A Jessica Jones and Luke Cage [See Appendix M]. ${ }^{490}$ Marvel Studios success has led other Hollywood studios to develop their own superhero cinematic universes, one example being Warner Bros., which is attempting to establish a DC Comics cinematic universe.

Warner Bros. is the frontrunner in developing an equivalent cinematic universe with its DC Comics characters. Warner Bros. has a clear advantage over Marvel Studios in that they have all of DC Comics' characters at their disposal, and have an entire comic book universe to adapt as they see fit. ${ }^{491}$ The current DC cinematic universe slate, announced on October 15, 2015 by Warner Bros.' CEO Kevin Tsujihara, consists of Batman Vs. Superman; Dawn of Justice (2016, Suicide Squad (2016), Wonder Woman (2017), Justice League: Part One (2017), The Flash (2018), Aquaman (2018), Shazam (2019), Justice League: Part Two (2019), Cyborg (2020) and Green Lantern (2020). ${ }^{492}$ Warner Bros. lacks an official showrunner of their DC Comics cinematic universe, as Marvel Studios has with Kevin Feige and Joss Whedon. However, Man of Steel director Zack Snyder (300, Watchmen) and screenwriter David S. Goyer (The Dark Knight Trilogy) are heavily involved in the production and development of the DC Comics films. ${ }^{493}$ Snyder is the director of Batman Vs. Superman: Dawn of Justice and is set to direct both Justice League films and Goyer is to write the screenplays for all three

\footnotetext{
${ }^{490}$ Referring to Marvel Studios' television casting see Kevin Jagernauth, “'Boardwalk Empire' \& 'Stardust' Star Charlie Cox To Play 'Daredevil' In Netflix Series,” Edward Davis, “'Breaking Bad' Star Krysten Ritter To Play Marvel's 'Jessica Jones'; Mike Colter May Play Luke Cage," and Nellie Andreeva, "Marvel Confirms Mike Colter As Luke Cage In 'Jessica Jones' Netflix Series.”

${ }^{491}$ Charlie Jane Anders, "Which Studio's Attempt to Copy Marvel's Movie Universe is Most Doomed?," io9, March 31, 2014, accessed April 2, 2014, http://io9.com/which-studios-attempt-to-copy-marvels-movie-universe-1555390988, 7.

492 Jason Concepcion, "Your Year-by-Year Guide to the 10 (10!) New DC Comics Movies Warner Bros. Plans Through 2020," Grantland, October 16, 2014, accessed October 16, 2014, http://grantland.com/hollywoodprospectus/your-year-by-year-guide-to-the-10-10-new-dc-comics-movies-warner-bros-plans-through-2020/, 1-7. ${ }^{493}$ Anders "Studio Copy," 3.
} 
films. ${ }^{494}$ The first film in Warner Bros.' tentative DC cinematic universe was Zack Snyder's Man of Steel (2013), starring Henry Cavill and Amy Adams, effectively introducing the character of Superman to a new movie-going generation. ${ }^{495}$ Rather than follow Marvel's footsteps and introduce each superhero with a film, and give audiences time to learn about and care for each hero, Warner Bros. has chosen to introduce a large cast of characters in Batman vs. Superman: Dawn of Justice, then follow up within a few years with even bigger Justice League films. ${ }^{496}$ The studio also faces further issues regarding its characters in its DC Comics cinematic universe.

Character development and tone are two crucial issues Warner Bros. face in the development of their DC Comics cinematic universe. The pressing issue for the studios is whether supporting characters such as Wonder Woman or Aquaman will make enough of an impression on audiences to successfully launch their own solo series later. ${ }^{497}$ Wonder Woman, which will to star Gal Gadot and to be directed by Patty Jenkins (Monster) with a screenplay by Jason Fuchs (Pan), will be an important film for Warner Bros. $^{498}$ It could not only be the first successful film adaptation of the most influential female superhero in comic books, but Wonder Woman might also the first standalone superhero film in the DC Comics cinematic universe. The film's success will depend on whether the studio does right by such an iconic character, and if audiences for Superman Vs. Batman: Dawn of Justice are intrigued and excited enough about the character of Wonder Woman to see the new film. The return of Batman in Batman Vs. Superman:

\footnotetext{
${ }^{494}$ Kevin Jagernauth, “Zack Snyder To Direct 'Justice League' For Warner Bros, 'Batman Vs. Superman' Will Lead Into Super Sequel," The Playlist, April 27, 2015, accessed January 24, 2015, http://blogs.indiewire.com/theplaylist/zacksnyder-to-direct-justice-league-for-warner-bros-batman-vs-superman-will-lead-into-super-sequel-20140427, 1. 
Dawn of Justice, with Ben Affleck being the newest iteration of the character, is another possible problem. With Christopher Nolan's The Dark Knight Rises to have been released only fours years prior to Batman Vs. Superman: Dawn of Justice, it may possible be too soon for audiences to accept or care about another Batman. ${ }^{499}$ The tone of the films is another possible issue; Man of Steel has established the DC cinematic universe on the realistic and gritty side of the superhero spectrum, in the manner of Christopher Nolan's Dark Knight trilogy. ${ }^{500}$ While Marvel Studios' films feature serious and dangerous situations, they also contain plenty of humor, as Iron Man 3 and Guardians of the Galaxy do, and are not overly dark and somber. In contrast Man of Steel features a horrendous and destructive battle in the climax of the film, which has been judged by some audiences and critics to have been excessive. ${ }^{501}$ The overly dark tone characteristic of the Warner Bros. films could inadvertently overwhelm audiences and alienate them from the characters, making them less likely to go to the theatre to see further films featuring the same characters.

A further factor that differentiates Marvel from its competitors concerns the ownership of the properties. In comparison to Warner Bros., which owns the complete rights to all of DC Comics' characters, Marvel Studios' only owns a majority of the Marvel Comics' characters, which means that no studio holds a monopoly on the Marvel Comics character rights. In the 1990s, as part of the company's plan to recuperate from its bankruptcy, Marvel sold off the rights of its characters to multiple studios [See Appendix J]. As of 2015, Marvel's characters are divided amongst four studios; Sony

\footnotetext{
${ }^{499}$ Anders "Studio Copy," 9.

${ }^{500}$ Ibid., 9 .

${ }^{501}$ Simon Brew, "Zack Snyder defends the mass destruction of Man Of Steel," Den of Geek, August 30, 2013, accessed January 24, 2015, http://www.denofgeek.com/movies/man-of-steel/27096/zack-snyder-defends-the-mass-destructionof-man-of-steel, 1.
} 
owns Spider-Man and all of Spider-Man's adjacent characters (ie. The Green Goblin, Venom etc.) and shares them with Marvel Studios, $20^{\text {th }}$ Century Fox owns the complete library of X-Men characters, along with Fantastic Four and its adjacent characters (ie. The Skrulls, the Badoon etc.), Universal owns Namor the Sub-Mariner, and Marvel Studios owns all remaining Marvel characters. ${ }^{502}$ In the last decade, the character rights of various characters have reverted back to Marvel's ownership, due to a clause regarding the ownership of Marvel characters; if a studio does not begin principal photography by a specified time, the character rights revert back to Marvel. ${ }^{503}$ Marvel has regained ownership of numerous characters, such as Daredevil and Elektra from $20^{\text {th }}$ Century Fox, the Hulk from Universal, and Blade from New Line Cinema, due to a studio's deadline elapsing. However, there is very little chance of Marvel Studios regaining full ownership of the $X$-Men and Spider-Man characters, as $20^{\text {th }}$ Century Fox and Sony know their Marvel characters are beyond value in the reality of a franchise oriented film industry with shrinking revenues and profits and in a post-Avengers superhero cinematic universe. The box office of both film franchises are large enough that $20^{\text {th }}$ Century Fox and Sony won't deliberately let the rights lapse, and the two studios are constantly remaking their superhero films and making spinoffs to ensure their characters don't revert back to Marvel. ${ }^{504}$ Sony announced the remake of the Spider-Man franchise in 2007 in order to prevent the Spider-Man rights to lapsing back to Marvel after Sam Raimi's plans for Spider-Man 4 fell through. ${ }^{505}$ There are also two particular characters who can be used

\footnotetext{
502 Carl Lee, “Answered: Which Studios Own Which Marvel Characters," Screenrant, October 6, 2014, accessed January 12, 2015, http://screenrant.com/marvel-comics-movies-characters-carl-6766/, 2-3.

${ }^{503}$ Ibid., 3.

${ }^{504}$ Ibid., 3.

505 Terri Schwartz, "Sam Raimi Explains Why Spider-Man 4 Didn’t Happen," Comic Book Resources, March 6, 2013 , accessed January 24, 2015. http://spinoff.comicbookresources.com/2013/03/06/sam-raimi-explains-why-spider-man-4didnt-happen/, 1.
} 
by Marvel Studios and $20^{\text {th }}$ Century Fox: brother and sister speedster Quicksilver and the Scarlet Witch. The heroes/supervillains in the comics are the children of Magneto, the archenemy of the X-Men, who later become members of the Avengers, thus occupying places in both X-Men and Avengers history. Kevin Feige has stated that legally both Marvel Studios and $20^{\text {th }}$ Century Fox can use Quicksilver and the Scarlet Witch in their films. ${ }^{506}$ This has led to the rare instance of two versions of a superhero existing concurrently; $20^{\text {th }}$ Century Fox was the first studio to use Quicksilver, with Evan Peters (American Horror Story) cast as the speedster for X-Men: Days of Future Past (2014) in the X-Men cinematic universe, while Aaron Taylor-Johnson (Kick-Ass, Anna Karenina) was cast as Quicksilver for the "MCU."507 While Marvel Studios does not have control of the Spider-Man and X-Men characters, the strength of its "MCU" demonstrates that it does not need those particular characters to be successful. $20^{\text {th }}$ Century Fox's control of the $X$-Men and Fantastic Four characters has allowed it to restart both franchises in the wake of the "MCU's" success.

Since the success of Marvel Studio's “MCU," $20^{\text {th }}$ Century Fox has recalibrated the $X$-Men franchise, giving it a fresh start with a new cast and narrative after the franchise's original trilogy, and made plans to restart the Fantastic Four franchise in 2015. $20^{\text {th }}$ Century Fox's $X$-Men franchise was arguably the first mainstream superhero franchise, embrace by the general public, comic book fans and critics for its characters and stories. However, the subpar critical and audience reception of X-Men: The Last Stand (2006) and X-Men Origins: Wolverine led to a stagnation of the $X$-Men franchise

\footnotetext{
${ }^{506}$ Edward Davis, "Kevin Feige Says Both Marvel \& Fox Can Use Quicksilver \& The Scarlet Witch In 'Avengers' \& 'X-Men' Films,” Playlist, April 20, 2012, accessed January 20, 2015. http://blogs.indiewire.com/theplaylist/kevin-feigesays-both-marvel-fox-can-use-quicksilver-the-scarlett-witch-in-avengers-x-men-films-20120420, 1.

${ }^{507}$ Referring to Quicksilver castings see Kevin Jagernauth, "Sorry 'The Avengers 2,' 'X-Men: Days Of Future Past' Will Get Quicksilver On The Big Screen First,” 1 and Edward Davis, “'Kick-Ass' Star Aaron Taylor-Johnson Confirmed To Play Quicksilver In 'Avengers: Age Of Ultron."'
} 
for the studio [See Appendix D]. In 2011 Fox released X-Men: First Class (2011), starring James McAvoy, Michael Fassbender and Jennifer Lawrence, set in the 1960s as a prequel to the original trilogy and as the beginning of a remake of the $X$-Men franchise. X-Men: First Class and the following X-Men film The Wolverine (2013), a standalone film focusing on Wolverine in Japan, laid the groundwork for creating a cohesive $X$-Men cinematic universe, while leading First Class' sequel X-Men: Days of Future Past, an adaptation of a popular $X$-Men comic storyline, to be rolled out. Directed by Bryan Singer, the director of X-Men and X2: X-Men United, Days of Future Past's time travel narrative allowed the film to have past and present $X$-Men casts exist within the same film and to reunite the classic $X$-Men cast, including Patrick Stewart, Sir Ian McKellan, Halle Berry and Ellen Page. ${ }^{508}$ Days of Future Past was a success, securing $\$ 233,921,534$ in the domestic box office and nearly $\$ 750$ million worldwide, making the film the highest grossing $X$-Men film in the franchise, while successfully reinventing the $X$-Men franchise for a new generation and winning back its fans [See Appendix D]. The film didn't completely fix all of its continuity issues, such as the loss of Magneto's powers and the supposed death of Professor X in X-Men: The Last Stand, but it succeeded in making a plausible interconnected universe from its films. ${ }^{509}$ Days of Future Past also paved a new path for future $X$-Men films while allowing the option of the old $X$-Men cast members appearing in cameos to establish future continuity of its universe. The film effectively erased the past mistakes of the $X$-Men franchise and allowed $20^{\text {th }}$ Century Fox to rework the franchise into a cinematic universe for audiences to consume.

\footnotetext{
${ }^{508}$ Referring to X-Men: Days of Future Past see Charlie Jane Anders, "Which Studio's Attempt to Copy Marvel's Movie Universe is Most Doomed?," 6 and Internet Movie Database (IMDb), "X-Men: Days of Future Past."

${ }^{509}$ Anders "Studio Copy," 6.
} 
X-Men: Days of Future Past provided $20^{\text {th }}$ Century Fox with a clean slate to create future $X$-Men films with a new cast and expand their $X$-Men universe, alongside its remake of the Fantastic Four. Due to X-Men: First Class being created as a pseudoremake of the franchise, it would allow the studio to recast key X-Men characters, and provide them the opportunity to make countless future movies in a linear narrative with a new cast. For Days of Future Past sequel, X-Men: Apocalypse (May 27, 2016), Tye Sheridan $(M u d)$, Sophie Turner (Game of Thrones) and Alexandra Shipp (House of Anubis) have been cast respectively as the young versions of Cyclops, Jean Grey, and Storm, hinting at the planning for future films featuring these characters. ${ }^{510}$ The production of multiple $X$-Men spinoffs is also underway, with Channing Tatum to play the titular Southern mutant hero in Gambit in November 2016 and Ryan Reynolds to reprise his role as motor mouth mutant assassin Deadpool from X-Men Origins:

Wolverine in February 2016, expanding the X-Men cinematic universe [See Appendix Q]. ${ }^{511} 20^{\text {th }}$ Century Fox is also planning to restart the Fantastic Four franchise. The studio has grounded the premise of four individuals who gain superpowers in a more realistic setting, and selected a cast of rising stars to support the film. Miles Teller (Whiplash), Kate Mara (House of Cards), Jaime Bell (Billy Elliot, Snowpiercer) and Toby Keball (Black Mirror, Dawn of the Planet of the Apes) will respectively play Mr. Fantastic, the Invisible Woman, the Thing, and super-villain Doctor Doom, with $20^{\text {th }}$ Century Fox demonstrating a commitment to diversity by casting Michael B. Jordan

\footnotetext{
${ }^{510}$ Kevin Jagernauth, "Tye Sheridan, Sophie Turner \& More Join 'X-Men: Apocalypse,' Patrick Stewart \& Ian McKellen Not Returning." Playlist, January 22, 2015. Accessed January 25, 2015. http://blogs.indiewire.com/theplaylist/tye-sheridan-sophie-turner-more-join-x-men-apocalypse-patrick-stewart-ianmckellen-not-returning-20150122, 1.

${ }^{511}$ Referring to $X$-Men spinoffs see Edward Davis, "Channing Tatum's 'X-Men' Spin-Off 'Gambit' Hired 'RoboCop' Writer \& Moves Forward,” and Mike Fleming Jr, "Ryan Reynolds In 'Deadpool' Deal.”
} 
(Fruitvale Station) as the Human Torch. ${ }^{512} 20^{\text {th }}$ Century Fox's ownership of the $X$-Men and Fantastic Four properties has led to tensions with the Marvel conglomerate.

Marvel Studios will not be regaining control of the X-Men and Fantastic Four properties anytime in the near future, but the conglomerate can still create a tenuous and uncomfortable environment for its competitors. Due to the Marvel character rights conditions, whereby if a studio doesn't make films with its Marvel characters within a specified time the rights revert back to Marvel, it is in Marvel's best interest for Sony and Fox to lose their rights to their big characters, because it would mean that Marvel would reclaim those popular, money-making franchises. ${ }^{513}$ In the 1980 s and 1990 s, the $X$-Men were Marvel's central comic franchise, with its merchandise ranging from to toys, to trading cards, and cartoons. ${ }^{514}$ However, Marvel controls the source material that Sony and Fox use, and has say when it comes to cartoons, toys, and licensing; thus, Marvel could downplay their favorite characters by limiting the merchandise. ${ }^{515}$ The lack of $X$ Men merchandise and promotion for $20^{\text {th }}$ Century Fox's X-Men Days of Future Past, and the absence of X-Men and Fantastic Four Marvel characters in comparison to the Marvel characters owned by Marvel Studios, from the company's promotion and from comic news at large, give some weight to claims of Marvel favoritism. ${ }^{516}$ Comics fans have claimed over the past few years that the $X$-Men have been put on the backburner by Marvel in order to promote and develop teams, such as Guardians of the Galaxy and the

\footnotetext{
${ }^{512}$ Referring to Fantastic Four (2015 casting see Beth Hanna, “'Fantastic Four' Has a Cast: Michael B. Jordan, Kate Mara, Miles Teller and Jamie Bell," 1 and Kevin Jagernauth, "Toby Kebbell Lining Up To Play 'Fantastic Four' Villain Dr. Doom," 1.

${ }^{513}$ Alex Abad-Santos, "Why Marvel wants the X-Men to fail," Vox, August 11, 2014, accessed October 15, 2014, http://www.vox.com/2014/8/11/5974743/marvels-X-men-conspiracy-theory-guardians-future, 5 .

${ }_{514}$ Ibid., 3 .

515 Ibid., 3.

${ }^{516}$ Referring to possible $X$-Men and Fantastic Four favoritism see Alex Abad-Santos, "Why Marvel wants the X-Men to fail," 6 and Jaime Weinman, "Marvel, Fox and the fantastic fracas," 2.
} 
Avengers, that they hold the film rights to. ${ }^{517}$ There have even been edicts issued to the Marvel comics creators and writers not to create any new characters for the "X-Men" and "Fantastic Four" comic series so as to not give $20^{\text {th }}$ Century Fox more characters to use in their films. ${ }^{518}$ There are also hints of antagonism on part of $20^{\text {th }}$ Century Fox. Both Marvel Studios and 20th Century Fox can use the characters of Quicksilver and the Scarlet Witch, and in 2013 Fox announced Quicksilver would be part of X-Men: Days of Future Past. ${ }^{519}$ This meant $20^{\text {th }}$ Century Fox's version of Quicksilver would be the first cinematic representation of the superhero, a full year ahead of Marvel Studios' Avengers: Age of Ultron, which also features the character of Quicksilver. ${ }^{520}$ This move was seen in the film industry as the gauntlet being thrown down by $20^{\text {th }}$ Century Fox, especially since the scene with Quicksilver in Days of Future Past was originally written for another character. ${ }^{521}$ Marvel Studios has also been working its way around the mutant heritage of Quicksilver and the Scarlet Witch. The brother and sister superheroes/villains are mutants in the comics, but the studio cannot legally use the term "mutant" in the "MCU," so there have been hints of recalibrating their backstory to be possible members of the Marvel superhuman race, the Inhumans. ${ }^{522}$ The Inhumans were an integral part of Marvel's "Infinity" comic book crossover event, where a Terrigen Mist bomb-the Terrigan Mist being what grants Inhumans their powers - was released on Earth, turning vast numbers of people into Inhumans. ${ }^{523}$ From an editorial standpoint, this comic storyline could provide a loophole for Marvel Studios to create $X$-Men-esque characters

\footnotetext{
${ }^{517}$ Abad-Santos, "X-Men to fail," 3.

${ }^{518}$ Ibid., 5.

${ }^{519}$ Weinman "Marvel, Fox," 2.

${ }^{520}$ Ibid., 2.

${ }^{521}$ Ibid., 2.

${ }^{522}$ Abad-Santos, "X-Men to fail," 7-8.

${ }^{523}$ Abad-Santos, "X-Men to fail," 7-8.
} 
without having to use the X-Men themselves with the additional benefit of expanding their cinematic universe. ${ }^{524}$ Marvel's cancellation of their progenitor comic book, "The Fantastic Four" is the most current example of the conglomerate exerting its dominance.

The cancellation of the classic Marvel Comics series "The Fantastic Four" has sobering repercussions for $20^{\text {th }}$ Century Fox. On October 12, 2014 at the New York Comic-Con, "Fantastic Four" series writer James Robinson confirmed the cancellation of the series, stating the series was "going away for a while." ${ }^{, 525}$ The comic's cancellation was unsettling as it meant the end of Marvel Comics' first and longest comic series of fifty-three years, from 1961 to present day, which had cemented Marvel Comics' status as one of the two comics giants in the industry, but also presents obstacles to $20^{\text {th }}$ Century Fox's Fantastic Four reboot. ${ }^{526}$ In Marvel's eyes, the "Fantastic Four" comic series would serve as free publicity promotion for audiences curious about the new Fantastic Four reboot and act as promotion for the film. ${ }^{527}$ Thus, it makes sense from a business perspective to cancel a series that would give free promotion to a rival studio that owns Marvel characters. "The Fantastic Four" has never been a bestseller, so there would be less chance of a fan revolt if it were cancelled, unlike the fan mutiny that would occur if Marvel attempted to cancel their "X-Men" comics. ${ }^{528}$ The "Fantastic Four" cancellation policy was enacted by Marvel CEO Isaac Perlmutter, and the ultimate damage to $20^{\text {th }}$ Century Fox is that they lost a venue in which potential audiences could learn and care

\footnotetext{
${ }^{524}$ Ibid., 7-8.

${ }^{525}$ Jonah Welland, "NYCC: Robinson Discusses End of 'Fantastic Four," Comic Book Resources, October 12, 2015, accessed October 15, 2014, http://www.comicbookresources.com/?page=article\&id=56237, 1.

${ }^{526}$ Abraham Riesman, "It's Tragic and Disappointing That Marvel Is Canceling Fantastic Four," Vulture, October 14, 2014, accessed October 15, 2014, http://www.vulture.com/2014/10/fantastic-four-comics-canceled-marvel.html, 2.

527 Weinman "Marvel, Fox," 2.

${ }^{528}$ Sean O’Neal, "Marvel's dealings with Spider-Man, X-Men, and Fantastic Four are a mess right now," A.V. Club, October 8, 2014, accessed October 15, 2014, http://www.avclub.com/article/marvels-dealings-spider-man-x-men-andfantastic-fo-210241, 1-2.
} 
about the "Fantastic Four" characters, which would have given people a reason to see the Fantastic Four reboot in theatres. If audiences do not care about a film's characters, or more importantly a franchise's characters, a film will most likely fail. The remaining Marvel characters not owned by Marvel Studios are Spider-Man and his related characters, which are owned by Sony.

Upon its remake of the Spider-Man franchise in 2012, which was done in order to prevent the rights from reverting back to Marvel, Sony has attempted to create a cinematic universe for Spider-Man, with mixed results. After the release of The Amazing Spider-Man in 2012, starring Andrew Garfield and Emma Stone, to the lowest domestic and worldwide box office of the total Spider-Man films at the time [See Appendix C]. Sony began planning a Spider-Man cinematic universe along the vein of the "MCU." The studio committed to two additional Amazing Spider-Man films, and two spin offs focusing on the classic Spider-Man villains Venom and the Sinister Six. ${ }^{529}$ Sara Vilkomerson's “The Amazing Spider-Plan!” gave the impression Sony was anxious to establish a Spider-Man cinematic universe in the face of the growth of franchises in the past five years. Amy Pascal, co-chairman of Sony, stated in a promotional article for The Amazing Spider-Man 2 for Entertainment Weekly that "[a Spider-Man universe] was something we had always planned on doing." ${ }^{530}$ Sony, displaying a one-size-does-not-fitall vision, also developed a "brain trust" of writers to shepherd in the Spider-Man cinematic universe. The group included Ed Solomon, Jeff Pinkner, Drew Goddard, and writers and producers of television series Alias and Paramount franchise Star Trek, Alex

\footnotetext{
${ }^{529}$ Sara Vilkomerson, “The Amazing Spider-Plan!," Entertainment Weekly, May 9, 2014, accessed May 30, 2014, http://www.ew.com/ew/article/0,,20801730,00.html, 1.

${ }^{530}$ Ibid., 1.
} 
Kurtzman and Roberto Orci. ${ }^{531}$ Unfortunately, The Amazing Spider-Man 2 debuted to unfavorable critical reviews, the lowest of all the Spider-Man films, and the final film's box office became the newest film with the lowest domestic and worldwide total in the total Spider-Man franchises [See Appendix D]. The failure of The Amazing Spider-Man 2 was a key factor leading to the momentous deal between Marvel Studios and Sony allowing for shared custody of the character of Spider-Man.

On February 9, 2015 Marvel Studios and Sony entered into a partnership that will lead to the two studios sharing Spider-Man, which will allow the character to appear in, and be a part of the "MCU." 532 Kevin Feige and Amy Pascal will co-produce all future Spider-Man films, with Matt Tolmach and Avi Arad, who have served as producers on both the first and second Spider-Man franchises, and will also serve as executive producers going forward. ${ }^{533}$ This announcement was unprecedented, not only due to Marvel Studios regaining partial ownership of one of their most popular Marvel Comics characters, but also because it marked new ground regarding inter-studio collaboration. As per the arrangement between Marvel Studios and Sony, Spider-Man is allowed to be incorporated into the "MCU" and Marvel Studios' films, and will appear in an as of yet unannounced Marvel Studios film prior to appearing in a new solo feature film on July 28, 2017. ${ }^{534}$ It is likely that the first "MCU" film in which the new Spider-Man will appear will be Captain America: Civil War, to be released in 2016, given that Spider-

\footnotetext{
${ }^{531}$ Gabe Toro, "Discuss: Why One Size Does Not Fit All For Superhero Franchises \& Where Sony Went Wrong With 'Amazing Spider-Man,” The Playlist, July 21, 2014, accessed March 20, 2014,

http://blogs.indiewire.com/theplaylist/discuss-why-once-size-does-not-fit-all-for-superhero-franchises-where-sonywent-wrong-with-amazing-spider-man-20140721, 3.

532 Borys Kit, “'Spider-Man' Swings to Marvel Studios in Major Sony Partnership," The Hollywood Reporter, February 9, 2015, ccessed February 28, 2015, 1.

${ }_{533}$ Ibid., 2.

534 Adam B Vary, "Spider-Man Joins Marvel Studios In Deal With Sony Pictures," Buzzfeed Entertainment, February 9, 2015, accessed February 28, 2015. http://www.buzzfeed.com/adambvary/spider-man-joining-marvel-studios-in-dealwith-sony-pictures\#.rt55JVmNn, 1.
} 
Man played a crucial role in the original Marvel Comics Civil War crossover event. ${ }^{535}$ The future solo film will be released by Sony, which will continue to finance, distribute, own, and exercise final creative control over future Spider-Man films. ${ }^{536}$ Spider-Man is now in a unique position in the superhero genre. While Spider-Man can now exist within the "MCU," and interact with "MCU" characters, he still retains his own franchise that is separate from the Marvel Studios and the "MCU," which will be managed by Sony. ${ }^{537}$ Furthermore, Sony and Marvel Studios are exploring opportunities to integrate characters from the "MCU" into future Spider-Man films. ${ }^{538}$ This is not simply a case of characters having their own franchises who exist within the same cinematic universe, and interact and team up with one another in further films. Sony and Marvel Studios' deal is the first step to cinematic universe crossovers and collaborations between studios, which could change and influence the superhero film genre in a manner comparable to the "MCU." As a result of the new Marvel Studios/Sony partnership, Sony's past plans regarding the Amazing Spider-Man films have been drastically altered.

Sony's hope for a Spider-Man cinematic universe was stunted due to the limited number of characters around when they can build and develop a universe. Built around one character, a Spider-Man universe, by itself, doesn't have the same breadth and depth as the "MCU" or even the $X$-Men cinematic universe. ${ }^{539}$ One of the reasons why SpiderMan works as a character in the comics is his capacity for interacting with and bouncing off other Marvel characters outside of his sphere of influence, such as X-Men, the Avengers and the Fantastic Four. By attempting to build a cinematic universe around

\footnotetext{
${ }^{535}$ Ibid., 1.

${ }^{536}$ Ibid., 1.

${ }^{537}$ Ibid., 1.

${ }^{538}$ Ibid., 1.

539 Anders "Studio Copy," 3.
} 
only Spider-Man as the nucleus, one makes the universe smaller and generic, and limits audience excitement for future films. ${ }^{540}$ As a result of the Marvel and Sony partnership regarding future Spider-Man films, The Amazing Spider-Man 3 and The Amazing SpiderMan 4 have been cancelled, and the creative team behind the Amazing Spider-Man films, including director Marc Webb, has been disbanded. ${ }^{51}$ Andrew Garfield, who portrayed the titular character in The Amazing Spider-Man (2012) and The Amazing Spider-Man 2 (2014), will not reprise the role, which will be recast. ${ }^{542}$ There has been much talk about the direction Marvel Studios and Sony will take the character, in particular as to whether or not Spider-Man will once again be Peter Parker, or Miles Morales, the Black Hispanic teenager in Ultimate Comics: Spider-Man who has taken on the mantle of Spider-Man. ${ }^{543}$ Miles Morales is a popular character amongst Marvel fans, and would go a long way to increase diversity within the "MCU" and the larger superhero genre. While the originally planned Amazing Spider-Man sequels have been cancelled, Sony has put the longplanned Sinister Six and Venom spin-offs on indefinite hiatus. ${ }^{544}$ These films will most likely be redeveloped to accommodate the new plans for Spider-Man to join the "MCU," and to better incorporate them into Sony's future Spider-Man plans. Drew Goddard, the director of the meta-horror film Cabin in the Woods (2012), and writer for television shows Buffy the Vampire Slayer, Angel, Alias, and Lost, is set to write and direct Sony and Marvel Studios' untitled 2017 Spider-Man film. ${ }^{545}$ The Marvel Studios and Sony

\footnotetext{
${ }^{540}$ Ibid., 3.

${ }^{541}$ Schilling, Dave. "It's Official: Marvel Gets to Borrow Spider-Man. Now What?.” Grantland, February 10, 2015. Accessed February 28, 2015. http://grantland.com/hollywood-prospectus/its-official-marvel-gets-to-borrow-spiderman-now-what/, 1 .

${ }^{542}$ Ibid., 1.

${ }^{543}$ Ibid., 1.

${ }^{544}$ Ibid., 1.

${ }^{545}$ Referring to Drew Goddard's involvement in Spider-Man see Kevin Jagernauth, "Drew Goddard To Write And Direct Sony \& Marvel's 'The Spectacular Spider-Man'; 'Sinister Six' Scrapped," 1 and Internet Movie Database (IMDb), "Drew Goddard."
} 
partnership has most likely been a blessing for both parties after the failure of The

Amazing Spider-Man 2. Prior to Marvel Studios and Sony's announcement, Roberto Orci had left the franchise, and the consensus from the cast, crew and fans appears to be that Sony attempted to do too many things at once in the film, in particular stuffing the film with too many Spider-Man villains to set up for The Sinister Six. ${ }^{546}$ Amazing Spider-Man star Andrew Garfield has stated "I read the script that [Alex Kurtzman] and [Bob Orci] wrote, and I genuinely loved it...[but] ultimately the studio [has] the final say in those movies because they're the tentpoles [films], so you have to answer to those people." ${ }^{, 54}$ At the time, Alex Kurtzman, a member of Sony's Amazing Spider-Man's “brain trust," bluntly stated the franchise is "up for grabs." In comparison to Marvel's strained relationship with $20^{\text {th }}$ Century Fox's regarding Fox's ownership of the X-Men and the Fantastic Four, Marvel does not have the same animosity regarding Sony ownership of Spider-Man. This is due to the transaction between Marvel and Sony, where Marvel purchased Sony's participation rights in Spider-Man merchandising in exchange for Marvel's participation rights in the making of Spider-Man films, allowing Marvel to control and profit from all Spider-Man merchandising. ${ }^{548}$ Spider-Man is still an iconic and beloved Marvel character, but its cinematic future is in flux at Sony, while Marvel Studios is in the enviable position of no longer requiring its once flagship characters of Spider-Man and the X-Men to be successful.

The attempts of Warner Bros., $20^{\text {th }}$ Century Fox, and Sony to establish their own

\footnotetext{
${ }^{546}$ Referring to Amazing Spider-Man delays see Oliver Lyttelton, "With Rumors Of A Delay For 'The Amazing SpiderMan 3,' Is Sony's Biggest Franchise In Trouble?,” 2 and Gabe Toro, “Discuss: Why One Size Does Not Fit All For Superhero Franchises \& Where Sony Went Wrong With “Amazing Spider-Man,"” 3.

${ }^{547}$ Zach Hollwedel, “Andrew Garfield Says Studio Cuts Damaged 'Amazing Spider-Man 2,' Alex Kurtzman Talks Venom," Playlist, September 11, 2014, accessed January 25, 2015, http://blogs.indiewire.com/theplaylist/andrewgarfield-says-studio-cuts-damaged-amazing-spider-man-2-alex-kurtzman-talks-venom-20140911.

${ }^{548}$ DCMarvelFreshman, "Disney Acquires Sony’s Merchandising Participation For The Amazing Spider-Man," ComicBookMovie.com, October 11, 2011, accessed October 15, 2014, http://www.comicbookmovie.com/fansites/MarvelFreshman/news/?a=49687, 1.
} 
superhero cinematic universes reflect the studios' response to the pressure of shrinking profit in the film industry, and their eagerness to become equals to Marvel Studios in superhero franchising. However, Marvel Studios still has the advantage over the other studios due to the firm establishment of their "MCU" brand, and how they have utilized transmedia and convergence culture to their advantage. The other studios have not yet been able to properly mobilize convergence culture for the benefit of their superhero cinematic universes to the same degree as has Marvel. A further question concerns whether future superhero cinematic universes can succeed in the face of the possible threat of superhero oversaturation, but as the saying goes: "imitation is the sincerest form of flattery." One must wait and see if Warner Bros., $20^{\text {th }}$ Century Fox, and Sony's attempts to frame their superhero films in the model of the "MCU" will lead to success, or ruin. 


\section{CONCLUSION}

The year 2015 concludes "Phase Two" of the official plan for the "Marvel Cinematic Universe," [hereafter referred to as the "MCU"] with Avengers: Age of Ultron, sequel of the Avengers to be released May 1, 2015, and Ant-Man, to be released July 17, 2015, bringing another meticulously planned and lucrative slate of Marvel Studios' films to a close [See Appendix Q]. The extended examination of Marvel Studios' and its "MCU" in the preceding chapters of this thesis illustrates the role of Marvel Studios in setting the standard for superhero franchising that other studios are scrambling to emulate.

Whether such emulation will produce comparable results remains an open question. The looming threat of an oversaturation of superhero films in the market could lead to disastrous consequences for the superhero plans of any studio. Within the fiveyear time period between 2015 and 2020, over thirty superhero films are to be released; in 2016 alone, assuming that these plans are realized, eight superhero films will be in theatres [See Appendix Q]. Paul Dergarabedian, the senior box-office analyst for mediatracking firm Rentrak, has noted that " 2015 is where we'll see the really perfect storm of comic-book films and spinoffs...it's either going to be a bloodbath or the greatest year at the box office ever - or both. ${ }^{, 549}$ The simple truth is that there is a very real possibility that the studios' bombardment of audiences with superhero films could turn against them and create a backlash. The comic book medium survives and thrives on decades-old characters and product lines being constantly rebooted with universe changing events that

\footnotetext{
${ }^{549}$ Barry Hertz, "Hollywood banks on profitable superhero universes," Macleans, January 4, 2014, accessed March 20 , 2014, http://www.macleans.ca/culture/a-comic-balm/, 2.
} 
alter the narrative status quo. ${ }^{550}$ In a medium where creators and writers can constantly "do over" their mistakes, it is standard procedure to end a long run of dragging, mediocre issues with a big starting-from-scratch ending, with the assumption that faithful, if irked, readers will stay on board and those who have drifted away will return. ${ }^{551}$ The comic book medium allows room for a margin of error that motion picture studios can't afford, especially during a period of decreasing movie attendance and shrinking profit throughout the film industry. The studios need an immediate decent-to-stellar film success, or else they flame out.

Warning signs of the fickle nature of audiences towards superhero franchising have been evident for some time. Marvel Studios faced their first major roadblock with Marvel's Agents of S.H.I.E.L.D. in 2013; the television show received mixed-to-negative reviews for the majority of the first season, alienating viewers who tuned into the show due to being fans of the Marvel Studios' films. ${ }^{552}$ The show managed to gain positive reception in the last five episodes, but experienced a large drop in ratings and has not been able to stabilize an audience, making it a last minute, but problematic, success for Marvel Studios. ${ }^{553}$ The series maintained enough strength to earn a second-season renewal, with the second season itself being an enormous improvement over the first, although it was most likely due to Marvel's Agents of S.H.I.E.L.D. airing on ABC, which is owned by Disney, who in turn owns Marvel Studios. ${ }^{554}$ As the owner of Marvel Studios and ABC, Disney is in the position to give time and leeway in the name of corporate synergy to Marvel's Agents of S.H.I.E.L.D. in order for the show focus on

\footnotetext{
${ }^{550}$ Mark Harris. “Are We at Peak Superhero?,” Grantland, May 22, 2014, accessed May 30, 2014, http://grantland.com/features/comic-book-movies-marvel-x-men-batman-dc-comics/, 1.

551 Ibid., 1 .

552 Ibid., 1.

${ }_{554}^{553}$ Ibid., 1.

${ }^{554}$ Ibid., 1.
} 
regroup and regaining an audience. Sony's Amazing Spider-Man 2 is another cautionary tale; its disappointing performance as the lowest grossing domestically of the five films in the series, suggests serious audience weariness with a premature remake of the property. ${ }^{555}$ The stumbling of Sony' Spider-Man plans also indicates that audiences are becoming tired of the comic book story formula of a single man facing tragedy who is then entrusted with great powers/rededicates his life to justice. Marvel Studios has successfully managed to tell entertaining narratives that use the comic book formula, but will soon have to be more creative in order to retain its critical and economic advantage over the other studios that own superhero properties. Marvel Studios has already begun to lay the groundwork for the future by establishing new franchises, such as Guardians of the Galaxy, Doctor Strange and Inhumans to eventually replace the longer running franchises, such as Iron Man and Thor, while introducing more diverse superheroes in their own solo films, such as Black Panther and Captain Marvel. Despite the familiarity of the standard comic book formula, Marvel Studios' films, and their sequels, have so far brought in increasing streams of revenues. The films of Marvel Studios' "Phase Two" yielded enormous revenue increases, due perhaps to the popularity of the Avengers, which created fans out of audience members who normally weren't interested in superhero films. Iron Man 3's gross rose 36\% from Iron Man 2's gross, and is currently the second most profitable Marvel Studios with a worldwide gross of $\$ 1,215,439,994$ billion dollars [See Appendix G]. Thor: The Dark World also received a 30\% bump, mirroring Iron Man 3 'gross increase, while Captain America: The Winter Soldier experienced 49\% increase [See Appendix G]. Marvel Studios' films are not without its faults, particularly the overabundance of white male Caucasian leads, which has been ${ }^{555}$ Ibid., 1. 
critiqued by in particular by fans of the "MCU," which can be attributed to a more diverse and educated audience, aware of diversity and visual representation (or rather the lack of) in Hollywood films. Nonetheless, Marvel Studios has successfully established itself as a signature of reliable quality entertainment. The success of Guardians of the Galaxy is a testament to the solidity of the Marvel Studios brand as a mark of quality. Guardians of the Galaxy was a risk due to being the first non-sequel film since 2012, only tangentially connected to the central "MCU," and featuring new and unorthodox characters to audiences, such as a talking tree and an anthropomorphic raccoon. However, audiences took a chance on this film from "the creators of Iron Man and the Avengers" and it ultimately made $\$ 774,176,000$ worldwide, enough to launch another superhero franchise for Marvel Studios [Appendix Q]. Marvel Studios also addressed criticism concerning their reliance on white male protagonists by announcing two new films as part of their "Phase Three" slate: Black Panther, which features one of the most well-known black superheroes in comics history, and Captain Marvel, a female Marvel superhero enjoying a resurgence in popularity [Appendix Q]. Marvel Studios' films still consist mostly of white men, but Black Panther and Captain Marvel demonstrate progress for more diverse superhero films, and the studio's ability to listen to criticism.

In its six years and ten films, Marvel Studios' has avoided critical and commercial failure while maintaining consistency and profit. ${ }^{556}$ It is unique in comparison to competing studios that produce superhero films. Marvel Studios makes only one to two films a year, and from 2016 onwards, it will make three films per year. In contrast, the superhero films produced by $20^{\text {th }}$ Century Fox Pictures, Sony Pictures and Warner Bros.

\footnotetext{
${ }^{556}$ Andrew Wheeler, "Why Marvel Studios Succeeds (And How It Will Fail If It Doesn't Diversify)," Comics Alliance, August 6, 2014, accessed August 28, 2014, http://comicsalliance.com/marvel-studios-success-marvel-moviesdiversity/, 1.
} 
Pictures make up only a small portion of a much larger production slate. ${ }^{557}$ Moreover, Marvel Studios, while a subsidiary of Walt Disney Motion Pictures, is largely autonomous and operates as its own brand, making only superhero films, allowing them to put all of their attention and resources into making each film that the other studios aren't capable to doing. ${ }^{558}$

As I have argued in the preceding pages of this thesis, Marvel Studios and its "MCU" have altered the status quo of superhero franchising, with the result that Hollywood studios now construct superhero films with a larger "cinematic universe" in mind. Through an investigation into Marvel Studios' background in the comics industry, its transformation in the wake of the Merrill Lynch deal, and its exploitation of convergence culture to create a sprawling transmedia franchise that has dominated the genre of superhero films, my intent has been both to explain how Marvel Studios has become the titan of superhero films and to contribute to a greater understanding of the essential role of superhero films in today's media culture.

\footnotetext{
${ }^{557}$ Ibid., 1.

${ }^{558}$ Ibid., 1.
} 


\section{BIBLIOGRAPHY}

Abad-Santos, Alex. "Why Marvel wants the X-Men to fail." Vox, August 11, 2014. Accessed October 15, 2014. http://www.vox.com/2014/8/11/5974743/marvels-Xmen-conspiracy-theory-guardians-future.

“About Merrill Lynch.” Merrill Lynch: Bank of America Corporation, 2014. Accessed November 6, 2014. http://www.ml.com/index.asp?id=7695 8134.

“About Comic-Con.” Comic-Con International: San Diego, 2015. Accessed January 18, 2015. http://www.comic-con.org/about.

Anders, Charlie Jane. "Which Studio's attempt to Copy Marvel's Movie Universe is Most Doomed?" io9, March 31, 2014. Accessed April 2, 2014. http://io9.com/which-studios-attempt-to-copy-marvels-movie-universe1555390988.

Andreeva, Nellie. "Marvel Confirms Mike Colter As Luke Cage In 'Jessica Jones' Netflix Series.” Deadline, December 22, 2014. Accessed December 24, 2014. http://deadline.com/2014/12/mike-colter-cast-luke-cage-jessica-jones-marvelnetflix-1201333646/.

“Angel.” Internet Movie Database (IMDb). N.p., n.d. Web. Accessed November 20, 2014. http://www.imdb.com/name/nm0000569/?ref_=nv_sr_1.

“Anthony Russo." Internet Movie Database (IMDb). N.p., n.d. Web. Accessed November 13, 2014. http://www.imdb.com/name/nm0751577/?ref =nv sr 1 .

“Astonishing X-Men.” n.d. Wikipedia September 14, 2014. Accessed November 20, 2014. http://en.wikipedia.org/wiki/Astonishing_X-Men.

Baker-Whitelaw, Gavia. "Being a Superhero Isn't Very Super for Marvel's “Avengers” Actors.” The Daily Dot, March 28, 2014. Accessed November 6, 2014. http://www.dailydot.com/fandom/marvel-avengers-contracts-gilded-cage/.

“Bob Rehak.” Swarthmore College, 2015. Accessed January 16, 2015. http://www.swarthmore.edu/profile/bob-rehak.

Bond, Paul and Borys Kit, "Marvel's Machine in Gear." The Hollywood Reporter, May 6, 2008. Accessed February 20, 2014.

http://www.hollywoodreporter.com/news/marvels-machine-gear-110880. 
Bond, Paul. "Analysts Split on Netflix Deal With Marvel For 'Defenders'.” The Hollywood Reporter, November 13, 2013. Accessed April 2, 2014. http://www.hollywoodreporter.com/news/netflix-marvels-defenders-analystssplit-655382.

Bourdaa, Melanie. "“Following the Pattern': The Creation of an Encyclopaedic Universe with Transmedia Storytelling." Adaptation 6.2 (Aug. 2013): 202-214. Accessed February 20, 2014.

Brew, Simon. "Zack Snyder defends the mass destruction of Man Of Steel." Den of Geek, August 30, 2013. Accessed January 24, 2015.

http://www.denofgeek.com/movies/man-of-steel/27096/zack-snyder-defends-themass-destruction-of-man-of-steel.

“Brian Michael Bendis.” n.d. Wikipedia October 24, 2014. Accessed November 8, 2014. http://en.wikipedia.org/wiki/Brian_Michael_Bendis.

"Buffy the Vampire Slayer." Internet Movie Database (IMDb). N.p., n.d. Web. Accessed November 20, 2014. http://www.imdb.com/name/nm0000569/?ref_=nv_sr_1.

Caldwell, John Thornton. Production Culture: Industrial Reflexivity and Critical Practice in Film and Television. North Carolina: Duke University Press, 2008.

“Captain America: The Winter Soldier." Box Office Mojo. Web. Accessed November 16, 2014. http://boxofficemojo.com/movies/?id=marvel14b.htm.

“Cobie Smulders.” Internet Movie Database (IMDb). N.p., n.d. Web. Accessed November 20, 2014. http://www.imdb.com/name/nm1130627/?ref_=nv_sr_1.

Concepcion, Jason. "I Feel Groot!" Grantland, August 1, 2014. Accessed November 18, 2014, http:/grantland.com/features/guardians-of-the-galaxy-get-on-up-review/.

Concepcion, Jason. "Your Year-by-Year Guide to the 10 (10!) New DC Comics Movies Warner Bros. Plans Through 2020.” Grantland, October 16, 2014. Accessed October 16, 2014, http://grantland.com/hollywood-prospectus/your-year-by-yearguide-to-the-10-10-new-dc-comics-movies-warner-bros-plans-through-2020/.

Concepcion, Jason. “A Movie-by-Movie Guide to Marvel's Phase 3, From Civil War to Infinity Wars." Grantland, October 29, 2014. Accessed November 16, 2014. http://grantland.com/hollywood-prospectus/a-movie-by-movie-guide-to-marvelsphase-3-from-civil-war-to-infinity-wars/.

Coonan, Clifford. “China Film Import Quota Will Open Up in 2017, Says Top Local Producer." The Hollywood Reporter, April 16, 2014. Accessed February 28, 2015. http://www.hollywoodreporter.com/news/china-film-import-quota-increase696708. 
"Daredevil." Box Office Mojo. Web. Accessed October 16, 2014. http://boxofficemojo.com/movies/?id=daredevil.htm.

Davis, Edward. "Kevin Feige Says Both Marvel \& Fox Can Use Quicksilver \& The Scarlet Witch In 'Avengers' \& 'X-Men' Films.” Playlist, April 20, 2012. Accessed January 20, 2015. http://blogs.indiewire.com/theplaylist/kevin-feige-says-bothmarvel-fox-can-use-quicksilver-the-scarlett-witch-in-avengers-X-men-films20120420.

Davis, Edward. “'Kick-Ass' Star Aaron Taylor-Johnson Confirmed To Play Quicksilver In 'Avengers: Age Of Ultron."' Playlist, October 20, 2013. Accessed January 20, 2015. http://blogs.indiewire.com/theplaylist/kick-ass-star-aaron-taylor-johnsonthe-frontrunner-to-play-quicksilver-in-avengers-2-20130608.

Davis, Edward. 'Channing Tatum's 'X-Men' Spin-Off 'Gambit' Hired 'RoboCop' Writer \& Moves Forward.” Playlist, November 1, 2014. Accessed November 14, 2014. http://blogs.indiewire.com/theplaylist/channing-tatums-X-men-spin-offgambit-hires-robocop-writer-is-moving-forward-20141101.

Davis, Edward. “'Breaking Bad' Star Krysten Ritter To Play Marvel's 'Jessica Jones'; Mike Colter May Play Luke Cage.” Playlist, December 4, 2014. Accessed December 5, 2014. http://blogs.indiewire.com/theplaylist/breaking-bad-starkrysten-ritter-to-play-marvels-jessica-jones-mike-colter-may-play-luke-cage20141204.

DCMarvelFreshman. “Disney Acquires Sony's Merchandising Participation For The Amazing Spider-Man." ComicBookMovie.com, October 11, 2011. Accessed Ocotber 15, 2014. http://www.comicbookmovie.com/fansites/MarvelFreshman/news/?a=49687.

The Deadline Team. "MARVEL-OUS STAR WATTAGE: Actors Assemble For ComicCon Panel Including 'The Avengers', 'Captain America', \& 'Thor'." Deadline, July 24, 2010. Accessed January 18, 2015. http://deadline.com/2010/07/star-wattagemarvel-assembles-the-avengers-for-comic-con-panel-56417/.

The Deadline Team. "Comic-Con: Loki Crashes Marvel Panel.” Deadline, July 21, 2013. Accessed January 18, 2015. http://deadline.com/2013/07/marvel-comic-conpanel-loki-video-546088/.

Dillard, Chris. "History of Marvel Studios." ComicUI, March 31-April 2, 2014. Accessed April 12, 2014. http://news.comicui.com/2014/03/history-of-marvelstudios-part-1/. 
Dionne, Zach. “J.K. Rowling's 'Harry Potter' Spinoff Will actually Be Three "Megamovies." Grantland, March 31, 2014. Accessed January 11, 2015. http://grantland.com/hollywood-prospectus/jk-rowling-trilogy/.

"Drew Goddard." Internet Movie Database (IMDb). N.p., n.d. Web. Accessed March 15, 2015. http://www.imdb.com/name/nm1206844/?ref_=nv_sr_1.

Elberse, Anita. Blockbusters: Hit-making, Risk-taking, and the Big Business of Entertainment. New York: Henry Holt and Co., 2013.

"Elektra.” Box Office Mojo. Web. Accessed October 16, 2014. http://boxofficemojo.com/movies/?id=elektra.htm.

"Fantastic Four: Rise of the Silver Surfer." Box Office Mojo. Web. Accessed October 16, 2014. http://boxofficemojo.com/movies/?id=fantasticfour2.htm.

Feldman, Brian. "Here Is Everything We Know About The Avengers 2: Age of Ultron." Vulture, August 19, 2014. Accessed August 28, 2014.

http://www.vulture.com/2014/08/everything-we-know-about-the-avengers-2-ageof-ultron.html.

Finke, Nikki. “'Avengers' Cast And Stingy Marvel Ready To Rumble Over Sequel Cast \& Strong-Arming." Deadline, May 7, 2013. Accessed November 6, 2014. http://deadline.com/2013/05/robert-downey-jr-avengers-marvel-negotiationsfight-491675/.

Finke, Nikki. "Robert Downey Jr. Signs For Two More 'Avengers.'” Deadline, June 20, 2013. Accessed November 9, 2014. http://deadline.com/2013/06/robert-downeyjr-signs-for-two-more-avengers-525915/.

"Firefly." Internet Movie Database (IMDb). N.p., n.d. Web. Accessed November 20, 2014. http://www.imdb.com/name/nm0000569/?ref_=nv_sr_1.

Fleming Jr., Mike. “Samuel Jackson Joins 'Iron' Cast.” Variety, February 25, 2009. Accessed November 6, 2014. http://variety.com/2009/film/news/samuel-jacksonjoins-iron-cast-1118000573/.

Fleming Jr., Mike. “Ryan Reynolds In 'Deadpool' Deal.” Deadline, December 4, 2014. Accessed December 4, 2014. http://deadline.com/2014/12/ryan-reynoldsdeadpool-fox-X-men-1201309406/.

Gardner, Eriq. "Marvel Seeks to Subpoena Google Over 'Avengers: Age of Ultron' Leak (Exclusive)." The Hollywood Reporter, November 6, 2014. Accessed November 10, 2014. http://www.hollywoodreporter.com/thr-esq/marvel-seeks-subpoenagoogle-avengers-747024. 
"Ghost Rider." Box Office Mojo. Web. Accessed October 16, 2014. http://boxofficemojo.com/movies/?id=ghostrider.htm.

"Guardians of the Galaxy." Box Office Mojo. Web. Accessed November 13, 2014. http://boxofficemojo.com/movies/?page=main\&id=marvel2014a.htm.

Graser, Marc. "How Marvel is Turning to Short Films to Sell More DVDs, Blu-rays." Variety, July 23, 2013. Accessed March 20, 2014. http://variety.com/2013/biz/news/how-marvel-is-turning-to-short-films-to-sellmore-dvds-blu-rays-1200566759/.

Graser, Marc. "Why Disney Chose to Put Marvel's New TV Shows in Netflix." Variety, November 7, 2013. Accessed March 20, 2014. http://variety.com/2013/digital/news/why-disney-chose-to-put-marvels-new-tvshows-on-netflix-1200805867/.

Greenwald, Andy. "Introduction to Blockbuster Filmmaking: Why a Couple of Community Producers Are a Perfect Match for Marvel.” Grantland, June 8, 2012. Accessed November 17, 2014. http://grantland.com/hollywoodprospectus/introduction-to-blockbuster-filmmaking-why-a-couple-of-communityproducers-are-an-inspired-choice-for-the-marvel-universe/.

"Gwyneth Paltrow." Internet Movie Database (IMDb). N.p., n.d. Web. Accessed November 16, 2014. http://www.imdb.com/name/nm0000569/?ref_=nv_sr_1.

Hanna, Beth. ''Fantastic Four' Has a Cast: Michael B. Jordan, Kate Mara, Miles Teller and Jamie Bell." Thompson on Hollywood, February 20, 2014. Accessed January 20, 2015. http://blogs.indiewire.com/thompsononhollywood/fantastic-four-sets-acast-michael-b-jordan-kate-mara-miles-teller-and-jamie-bell.

Hanley, Ken. "Universally Speaking: Marvel \& The Director's Chair." Starlog, July 14, 2014. Accessed November 6, 2014. http://www.starlog.com/universallyspeaking-marvel-the-directors-chair/.

Hollwedel, Zach. "Andrew Garfield Says Studio Cuts Damaged 'Amazing Spider-Man 2,' Alex Kurtzman Talks Venom.” Playlist, September 11, 2014. Accessed January 25, 2015. http://blogs.indiewire.com/theplaylist/andrew-garfield-says-studio-cutsdamaged-amazing-spider-man-2-alex-kurtzman-talks-venom-20140911.

Howe, Sean. Marvel Comics: The Untold Story. New York: Harper Perennial, 2012.

Hughes, Mark. "Why Marvel Is Defining The Modern Superhero Film Genre." Forbes, October 10, 2013. Accessed February 20, 2014. http://www.forbes.com/sites/markhughes/2013/10/29/why-marvel-is-defining-themodern-superhero-film-genre/. 
Hughes, Mark. “'Wonder Woman' Film Sets Sights On Jason Fuchs.” Forbes, December 4, 2014. Accessed December 6, 2014.

http://www.forbes.com/sites/markhughes/2014/12/04/wonder-woman-film-setssights-on-jason-fuchs/.

“The Hulk." Box Office Mojo. Web. Accessed October 16, 2014. http://boxofficemojo.com/movies/?id=hulk.htm.

Ioannidou, Elisavet, "Adapting Superhero Comics for the Big Screen: Subculture for the Masses.” Adaptation 6.2 (Aug. 2013): 230-238. Accessed February 20, 2014.

“Iron Man.” Box Office Mojo. Web. Accessed November 16, 2014. http://boxofficemojo.com/movies/?id=ironman.htm.

Jagernauth, Kevin. "Sorry 'The Avengers 2,' 'X-Men: Days Of Future Past' Will Get Quicksilver On The Big Screen First.” Playlist, May 23, 2013. Accessed January 24, 2015. http://blogs.indiewire.com/theplaylist/sorry-the-avengers-2-x-men-daysof-future-past-will-get-quicksilver-on-the-big-screen-first-20130523.

Jagernauth, Kevin. “Toby Kebbell Lining Up To Play 'Fantastic Four' Villain Dr. Doom.” The Playlist, April 1, 2014. Accessed January 25, 2015. http://blogs.indiewire.com/theplaylist/toby-kebbell-lining-up-to-play-fantasticfour-villain-dr-doom-20140401.

Jagernauth, Kevin. 'ZZack Snyder To Direct 'Justice League' For Warner Bros, 'Batman Vs. Superman' Will Lead Into Super Sequel.” The Playlist, April 27, 2014. Accessed January 24, 2015. http://blogs.indiewire.com/theplaylist/zack-snyder-todirect-justice-league-for-warner-bros-batman-vs-superman-will-lead-into-supersequel-20140427.

Jagernauth, Kevin. “'Boardwalk Empire' \& 'Stardust' Star Charlie Cox To Play 'Daredevil' In Netflix Series.” Playlist, May 27, 2014. Accessed May 30, 2014. http://blogs.indiewire.com/theplaylist/rumor-boardwalk-empire-stardust-starcharlie-cox-to-play-daredevil-in-netflix-series-20140527.

Jagernauth, Kevin. "Comic Roundup: Adam McKay May Direct A Marvel Movie, Quicksilver To Appear In 'X-Men: Apocalypse' \& More.” Playlist, October 24, 2014. Accessed October 15, 2014. http://blogs.indiewire.com/theplaylist/comicsroundup-adam-mckay-may-direct-a-marvel-movie-quicksilver-to-appear-in-Xmen-apocalypse-and-more-20141024.

Jagernauth, Kevin. "Marvel Wanted Spider-Man For 'Captain America: The Civil War'; '23 Jump Street' To Crossover With 'Men In Black."' Playlist, December 10, 2014. Accessed December 12, 2014. http://blogs.indiewire.com/theplaylist/marvelwanted-spider-man-for-captain-america-the-civil-war-23-jump-street-tocrossover-with-men-in-black-20141210. 
Jagernauth, Kevin. "Tye Sheridan, Sophie Turner \& More Join 'X-Men: Apocalypse,' Patrick Stewart \& Ian McKellen Not Returning." Playlist, January 22, 2015. Accessed January 25, 2015. http://blogs.indiewire.com/theplaylist/tye-sheridansophie-turner-more-join-X-men-apocalypse-patrick-stewart-ian-mckellen-notreturning-20150122.

Jagernauth, Kevin. "Drew Goddard To Write And Direct Sony \& Marvel's 'The Spectacular Spider-Man'; 'Sinister Six' Scrapped.” Playlist, March 2, 2015. Accessed March 15, 2015. http://blogs.indiewire.com/theplaylist/drew-goddardto-write-and-direct-sony-marvels-the-spectacular-spider-man-sinister-sixscrapped-20150302.

“James Gunn.” Internet Movie Database (IMDb). N.p., n.d. Web. Accessed November 13, 2014. http://www.imdb.com/name/nm0348181/?ref_=fn_al_nm_1.

“Jeff Bridges." Internet Movie Database (IMDb). N.p., n.d. Web. Accessed November 16, 2014. http://www.imdb.com/name/nm0000313/?ref_nv_sr_1.

Jenkins, Henry. "Introduction: Worship at the Alter of Convergeance: A New Paradigm for Understanding Media Change." In Convergence Culture: Where Old and New Media Collide. New York: New York University Press, 2006.

Jenkins, Henry. "Searching for the Origami Unicorn: The Matrix and Transmedia Storytelling." In Convergence Culture: Where Old and New Media Collide. New York: New York University Press, 2006.

Jenkins, Henry. "Transmedia Storytelling 101," Confessions of an Aca-Fan, March 22, 2007. Accessed February 22, 2014. http://henryjenkins.org/2007/03/transmedia_storytelling_101.html.

“Joe Russo.” Internet Movie Database (IMDb). N.p., n.d. Web. Accessed November 13, 2014. http://www.imdb.com/name/nm0751648/?ref_nv sr_1.

Johnson, Derek. " Cinematic destiny: Marvel Studios and the trade stories of industrial convergence," Cinema Journal 52.1 (Fall 2012): 1-24. Accessed February 21, 2014.

Johnson, Derek. Media Franchising: Creative License and Collaboration in the Culture Industries. New York: NYU Press, 2013.

“Jon Favreau." Internet Movie Database (IMDb). N.p., n.d. Web. Accessed November 13, 2014. http://www.imdb.com/name/nm0269463/?ref _nv sr 1.

"Kenneth Branagh." Internet Movie Database (IMDb). N.p., n.d. Web. Accessed November 13, 2014. http://www.imdb.com/name/nm0000110/?ref_=nv_sr_1. 
Kit, Borys. "The Avenger: Q\&A with Kevin Feige." The Hollywood Reporter, July 21, 2009. Accessed February 20, 2014.

http://www.hollywoodreporter.com/news/qampa-kevin-feige-86744.

Kit, Borys. "'Spider-Man' Swings to Marvel Studios in Major Sony Partnership.” The Hollywood Reporter, February 9, 2015. Accessed February 28, 2015.

Kit, Borys. "Russo Brothers to Direct 'Avengers: Infinity War' Part 1 and 2." The Hollywood Reporter, March 23, 2015. Accessed March 23, 2015.

http://www.hollywoodreporter.com/heat-vision/russo-brothers-direct-avengers-infinity$\underline{783685}$

Lee, Carl. "Answered: Which Studios Own Which Marvel Characters.” Screenrant, October 6, 2014. Accessed January 12, 2015. http://screenrant.com/marvelcomics-movies-characters-carl-6766/.

Li, David K. “\$carJo Makes' em Pay.” NYPost, July 9, 2012. Accessed November 9, 2014. http://nypost.com/2012/07/09/carjo-makes-em-pay/.

Leonard, Devin. "Calling All Superheroes." Fortune, May 23, 2007. Accessed February 20, 2014.

http://archive.fortune.com/magazines/fortune/fortune archive/2007/05/28/100034 246/index.htm.

Leonard, Devin. “The Pow! Bang! Bam! Plan to Save Marvel, Starring B-List Heroes." Bloomberg Businessweek, April 2, 2013. Accessed April 20, 2014. http://www.businessweek.com/printer/articles/192489-kevin-feige-marvelssuperhero-at-running-movie-franchises.

Lopez, John. "How 'Guardians of the Galaxy' Cherry-Bombed the Box Office and Made Off With All of Our Money." Grantland, August 4, 2014. Accessed November 18, 2014. http://grantland.com/hollywood-prospectus/how-guardians-of-thegalaxy-cherry-bombed-the-box-office-and-made-off-with-all-of-our-money/.

Lyttelton, Oliver. "With Rumors Of A Delay For 'The Amazing Spider-Man 3,' Is Sony's Biggest Franchise In Trouble?" The Playlist, June 13, 2014. Accessed June 13, 2014. http://blogs.indiewire.com/theplaylist/with-rumors-of-a-delay-for-theamazing-spider-man-3-is-sonys-biggest-franchise-in-trouble-20140613.

“Marvel's The Avengers.” Box Office Mojo. Web. Accessed November 16, 2014. http://boxofficemojo.com/movies/?id=avengers11.htm.

"Marvel Animation." n.d. Wikipedia, last edited October 13, 2014. Accessed November 8, 2014. http://en.wikipedia.org/wiki/Marvel_Animation. 
“Marvel's Agents of S.H.I.E.L.D.” Marvel.com. Accessed January 18, 2015. http://marvel.com/tv/show/190/marvels_agents_of_shield.

Masters, Kim. "Haggling With the Stars.” The Daily Beast, April 2, 2009. http://www.thedailybeast.com/articles/2009/04/02/haggling-with-the-stars.html.

McCarthy, Tyler. "'Avengers: Age Of Ultron' Trailer Breaks Records, Marvel Promises More Footage During 'Agents Of SHIELD."' International Business Times, October 26, 2014. Accessed January 18, 2015. http://www.ibtimes.com/avengersage-ultron-trailer-breaks-records-marvel-promises-more-footage-during-agents1714697.

McMillan, Graeme. "From DVD to ABC: Why Marvel's 'One-Shots' Matter." The Hollywood Reporter, September 23, 2013. Accessed March 20, 2014. http://www.hollywoodreporter.com/live-feed/dvd-abc-why-marvels-one-634738.

Miller, Ross. “Iron Man is Forever. Robert Downey Jr. Isn't.” The Verge, October 16, 2014. Accessed November 6, 2014. http://www.theverge.com/2014/10/16/6985725/marvel-iron-man-is-forever-rdjisnt.

“Non-Recourse Debt.” Investopedia, LLC, 2015. Accessed January 16, 2015. http://www.investopedia.com/terms/n/nonrecoursedebt.asp.

Obst, Lynda. Sleepless in Hollywood: Tales from the New Abnormal in the Movie Business. New York: Simon \& Schuster, 2013.

O’Neal, Sean. "Marvel's dealings with Spider-Man, X-Men, and Fantastic Four are a mess right now." A.V. Club, October 8, 2014. Accessed October 15, 2014. http://www.avclub.com/article/marvels-dealings-spider-man-x-men-and-fantasticfo-210241.

Panosian, Diane. "Behind The Money of Marvel's Mighty Movies.” Studio System News, May 2, 2013. Accessed February 20, 2014. http://www.studiosystemnews.com/behind-the-money-of-marvels-mightymovies/.

Pascale, Amy. Joss Whedon: the Biography. Chicago: Chicago Review Press Incorporated, 2014.

Patches, Matt. "The Marvel Way: How the Comic-Book Studio Chooses Its Directors." Grantland, November 6, 2013. Accessed March 20, 2014.

http://grantland.com/hollywood-prospectus/the-marvel-way-how-the-comic-book-studiochooses-its-directors/?src=mobile. 
Perez, Rodrigo. “Why Edgar Wright Left Marvel's 'Ant-Man': Analysis \& The Screenplay Rumors.” The Playlist, May 24, 2014. Accessed November 13, 2014. http://blogs.indiewire.com/theplaylist/why-edgar-wright-left-marvels-ant-mananalysis-the-screenplay-rumors-20140524.

"Peyton Reed." Internet Movie Database (IMDb). N.p., n.d. Web. Accessed November 13, 2014. http://www.imdb.com/name/nm0715636/?ref $=$ nv sr 1 .

Puchko, Kristy. "Terrence Howard Left Iron Man 2 Because They Would Only Pay Him \$1 Million.” CinemaBlend, March 18, 2013. Accessed November 9, 2014. http://www.cinemablend.com/new/Terrence-Howard-Left-Iron-Man-2-BecauseThey-Would-Pay-Him-1-Million-36432.html.

“The Punisher.” Box Office Mojo. Web. Accessed October 16, 2014. http://boxofficemojo.com/movies/?id=punisher.htm.

“Punisher: War Zone.” Box Office Mojo. Web. Accessed October 16, 2014. http://boxofficemojo.com/movies/?id=punisher2.htm.

Reiss, Robert. "How Marvel Became a Business Superhero.” Forbes, February 1, 2010. Accessed February 20, 2014. http://www.forbes.com/2010/02/01/peter-cuneomarvel-leadership-managing-turnaround.html.

Riesman, Abraham. "It's Tragic and Disappointing That Marvel Is Canceling Fantastic Four." Vulture, October 14, 2014. Accessed October 15, 2014. http://www.vulture.com/2014/10/fantastic-four-comics-canceled-marvel.html.

"Robert A. Iger." The Walt Disney Company. Accessed November 14, 2014. http://thewaltdisneycompany.com/about-disney/leadership/ceo/robert-iger.

Rogers, Adam. "How Marvel Unified Its Movie Universe (And Why That Won't Be Easy for DC)." Wired, August 7, 2013. Accessed November 8, 2014. http://www.wired.com/2013/08/kevin-feige-marvel-dc-movies/all/.

Salkowitz, Rob. Comic-Con and the Business of Pop Culture: What the World's Wildest Trade Show Can Tell Us About the Future of Entertainment. New York: McGraw-Hill, 2012.

Schwartz, Terri. "Sam Raimi Explains Why Spider-Man 4 Didn’t Happen." Comic Book Resources, March 6, 2013. Accessed January 24, 2015. http://spinoff.comicbookresources.com/2013/03/06/sam-raimi-explains-whyspider-man-4-didnt-happen/.

Schilling, Dave. "It's Official: Marvel Gets to Borrow Spider-Man. Now What?." Grantland, February 10, 2015. Accessed February 28, 2015. 
http://grantland.com/hollywood-prospectus/its-official-marvel-gets-to-borrowspider-man-now-what/.

Scott, A.O. "Heavy Suit, Light Touches." The New York Times, May 2, 2008. Accessed November 16, 2014. http://www.nytimes.com/2008/05/02/movies/02iron.html?_r=0.

"Scott Derrickson." Internet Movie Database (IMDb). N.p., n.d. Web. Accessed November 13, 2014. http://www.imdb.com/name/nm0220600/?ref_=nv_sr_1.

“Serenity.” Internet Movie Database (IMDb). N.p., n.d. Web. Accessed November 20, 2014. http://www.imdb.com/name/nm0000569/?ref_=nv_sr_1.

"Shane Black." Internet Movie Database (IMDb). N.p., n.d. Web. Accessed November 13, 2014. http://www.imdb.com/name/nm0000948/?ref_=fn_al_nm_1.

“Spider-Man.” Box Office Mojo. Web. Accessed October 16, 2014. http://boxofficemojo.com/movies/?id=spiderman.htm.

Strom, Matt. "Get Ready for Marvel Studios: Assembling a Universe With 3 New Clips." Marvel.com, March 17, 2014. Accessed January 18, 2014.

http://marvel.com/news/tv/22159/get_ready_for_marvel_studios_assembling_a_u niverse_with_3_new_clips.

"The Salaries of Marvel's The Avengers." TheRichest, July 11, 2012. Accessed November 9, 2014. http://www.therichest.com/expensivelifestyle/entertainment/marvels-the-avengers-salaries/.

"Synergy." Oxford Dictionaries.com. 2015. http://www.oxforddictionaries.com/definition/english/synergy.

“The Amazing Spider-Man 2." Box Office Mojo. Web. Accessed October 16, 2014. http://www.boxofficemojo.com/movies/?id=amazingspiderman2.htm.

Toro, Gabe. "Discuss: Why One Size Does Not Fit All For Superhero Franchises \& Where Sony Went Wrong With 'Amazing Spider-Man."' The Playlist, July 21, 2014. Accessed March 20, 2014. http://blogs.indiewire.com/theplaylist/discusswhy-once-size-does-not-fit-all-for-superhero-franchises-where-sony-went-wrongwith-amazing-spider-man-20140721.

Tryon, Chuck. Reinventing Cinema: Movies in the Age of Media Convergence. New Jersey: Rutgers University Press, 2009.

"US Inflation Calculator." Coinnews Media Group LLC (Coin News). 2008. Accessed October 8, 2013. 2008. https://owl.english.purdue.edu/owl/resource/717/05/. 
Vary, Adam B. "Spider-Man Joins Marvel Studios In Deal With Sony Pictures." Buzzfeed Entertainment, February 9, 2015. Accessed February 28, 2015. http://www.buzzfeed.com/adambvary/spider-man-joining-marvel-studios-in-dealwith-sony-pictures\#.rt55JVmNn.

Vilkomerson, Sara. “The Amazing Spider-Plan!” Entertainment Weekly, May 9, 2014. Accessed May 30, 2014, http://www.ew.com/ew/article/0,20801730,00.html.

"Warner Bros. Company History.” Warner Bros. Entertainment Inc., 2014. Accessed October 15, 2014. http://www.warnerbros.com/studio/about/company-history.

Weinman, Jaime. "The decline of Disney." Macleans, July 6, 2013. Accessed June 6, 2015. http://www.macleans.ca/culture/movies/the-mouse-eats-itself/.

Weinman, Jaime. "Why is it so hard to make a successful TV spinoff of a hit film?" Macleans, May 25, 2014. Accessed May 30, 2015. http://www.macleans.ca/culture/television/youd-never-see-this-in-the-movies/.

Weinman, Jaime. "Marvel, Fox and the fantastic fracas." Macleans, June 5, 2014. Accessed June 12, 2014. http://www.macleans.ca/culture/movies/marvel-fox-andthe-fantastic-fracas/.

Welland, Jonah. "Isaac Perlmutter New CEO Marvel Enterprises.” Comic Book Resources, October 15, 2004. Accessed November 6, 2014. http://www.comicbookresources.com/?page=article\&old=1\&id=4310.

Welland, Jonah. "NYCC: Robinson Discusses End of 'Fantastic Four.'” Comic Book Resources, October 12, 2015. Accessed October 15, 2014. http://www.comicbookresources.com/?page=article\&id=56237.

Wheeler, Andrew. "Why Marvel Studios Succeeds (And How It Will Fail If It Doesn't Diversify)." Comics Alliance, August 6, 2014. Accessed August 28, 2014. http://comicsalliance.com/marvel-studios-success-marvel-movies-diversity/.

Wilding, Josh. "Marvel Studios Clash with THE AVENGERS 2 Stars Over Money; Cast Threatening to Quit?” ComicBookMovie.com, May 7, 2013. Accessed November $6,2014$. http://www.comicbookmovie.com/fansites/JoshWildingNewsAndReviews/news/? $\mathrm{a}=79087$.

Wise, Stephen. "Movie Terms That Should Be Returned." FilmVerse, November 30, 2011. Accessed January 10, 2015. http://filmverse.com/2011/11/30/movie-termsthat-should-be-retired/.

“The Wolverine.” Box Office Mojo. Web. Accessed October 16, 2014. http://boxofficemojo.com/movies/?id=wolverine $2 . \mathrm{htm}$. 
“X-2: X-Men United.” Box Office Mojo. Web. Accessed October 16, 2014. http://boxofficemojo.com/movies/?id=x2.htm.

“X-Men: The Last Stand.” Box Office Mojo. Web. Accessed October 16, 2014. http://boxofficemojo.com/movies/?id=x3.htm.

“X-Men Origins: Wolverine.” Box Office Mojo. Web. Accessed October 16, 2014. http://boxofficemojo.com/movies/?id=wolverine.htm.

“X-Men: First Class.” Box Office Mojo. Web. Accessed October 16, 2014. http://www.boxofficemojo.com/movies/?id=xmenfirstclass.htm.

“X-Men: Days of Future Past.” Box Office Mojo. Web. Accessed October 16, 2014. http://boxofficemojo.com/movies/?id=xmen2014.htm.

Yaniz Jr., Robert. "Robert Downey Jr. on Iron Man Potentially Being Recast After 'The Avengers 2." Screenrant, November 2, 2013. Accessed November 12, 2014. http://screenrant.com/avengers-2-iron-man-robert-downey-jr-recasting/.

Zaluczkowska, Anna. "Storyworld: the Bigger Picture, investigating the world of multiplatform/ transmedia production and its affect on storytelling processes." Journal of Screenwriting 3.1 (2011): 83-101. Accessed February 22, 2014. 


\section{APPENDICES}

\section{$\underline{\text { Appendix A }}$}

Major Superhero Films Released Pre-Superhero Boom (2000)

\begin{tabular}{|l|l|l|l|l|l|}
\hline Title of Film & Release Date & Budget & $\begin{array}{l}\text { Domestic Box } \\
\text { Office }\end{array}$ & $\begin{array}{l}\text { Foreign Box } \\
\text { Office }\end{array}$ & Total Box Office \\
\hline Superman & $\begin{array}{l}\text { December 15, } \\
1978\end{array}$ & $\$ 55$ million & $\$ 134,218,018$ & $\$ 166,000,000$ & $\$ 300,218,018$ \\
\hline Superman II & June 19, 1981 & $\$ 54$ million & $\$ 108,185,706$ & - & $\$ 108,185,706$ \\
\hline Superman III & June 17, 1983 & $\$ 39$ million & $\$ 59,950,623$ & & $\$ 59,950,623$ \\
\hline $\begin{array}{l}\text { Superman IV: } \\
\text { The Quest for } \\
\text { Peace }\end{array}$ & July 24, 1987 & $\$ 17$ million & $\$ 15,681,020$ & - & $\$ 15,681,020$ \\
\hline Batman & June 23, 1989 & $\$ 35$ million & $\$ 251,188,924$ & $\$ 160,160,000$ & $\$ 411,348,941$ \\
\hline $\begin{array}{l}\text { Batman } \\
\text { Returns }\end{array}$ & June 19, 1992 & $\$ 80$ million & $\$ 162,831,698$ & $\$ 103,990,656$ & $\$ 266,822,354$ \\
\hline $\begin{array}{l}\text { Batman } \\
\text { Forever }\end{array}$ & June 16, 1995 & $\$ 100$ million & $\$ 184,031,112$ & $\$ 152,498,032$ & $\$ 336,529,032$ \\
\hline $\begin{array}{l}\text { Batman and } \\
\text { Robin }\end{array}$ & June 20, 1997 & $\$ 125$ million & $\$ 107,325,195$ & $\$ 130,881,927$ & $\$ 238,207,122$ \\
\hline Steel & August 15, 1997 & $\$ 16$ million & $\$ 1,710,972$ & & $\$ 1,710,972$ \\
\hline Blade & August 21, 1998 & $\$ 45$ million & $\$ 70,087,718$ & $\$ 61,095,812$ & $\$ 131,183,530$ \\
\hline
\end{tabular}

The information used from the above table was drawn from Box Office Mojo and The Numbers.

Accessed October 16, 2014. 


\section{Appendix B}

Major Film Productions of Marvel Comics Characters Non-Affiliated with Marvel Studios

\begin{tabular}{|l|l|l|l|l|l|}
\hline Title of Film & Release Date & Budget & $\begin{array}{l}\text { Domestic Box } \\
\text { Office }\end{array}$ & Foreign Box Office & Total Box Office \\
\hline Howard the Duck & August 1, 1986 & $\$ 37$ million & $\$ 16,295,774$ & $\$ 21,667,000$ & $\$ 37,962,774$ \\
\hline Blade & August 21, 1998 & $\$ 45$ million & $\$ 70,087,718$ & $\$ 61,095,812$ & $\$ 131,183,530$ \\
\hline X-Men & July 14, 2000 & $\$ 75$ million & $\$ 157,299,171$ & $\$ 139,039,810$ & $\$ 296,339,527$ \\
\hline Blade II & March 22, 2002 & $\$ 54$ million & $\$ 82,348,319$ & $\$ 72,661,713$ & $\$ 155,010,032$ \\
\hline Spider-Man & May 3, 2002 & $\$ 139$ million & $\$ 403,706,375$ & $\$ 418,002,176$ & $\$ 821,708,551$ \\
\hline Daredevil & February 14, 2003 & $\$ 78$ million & $\$ 102,543,518$ & $\$ 76,636,200$ & $\$ 179,179,718$ \\
\hline X2: X-Men United & May 2, 3003 & $\$ 110$ million & $\$ 214,949,694$ & $\$ 192,761,855$ & $\$ 407,711,549$ \\
\hline Hulk & June 20, 2003 & $\$ 137$ million & $\$ 132,177,234$ & $\$ 113,183,246$ & $\$ 245,360,480$ \\
\hline The Punisher & April 16, 2004 & $\$ 33$ million & $\$ 33,810,189$ & $\$ 20,889,916$ & $\$ 54,700,105$ \\
\hline Spider-Man 2 & June 30, 2004 & $\$ 200$ million & $\$ 373,585,825$ & $\$ 410,180,516$ & $\$ 783,766,341$ \\
\hline Blade: Trinity & December 8,2004 & $\$ 65$ million & $\$ 52,411,906$ & $\$ 76,493,460$ & $\$ 128,905,366$ \\
\hline Elektra & January 14, 2005 & $\$ 43$ million & $\$ 24,409,722$ & $\$ 32,271,844$ & $\$ 56,681,566$ \\
\hline Fantastic Four & July 8, 2005 & $\$ 100$ million & $\$ 154,696,080$ & $\$ 175,883,639$ & $\$ 330,579,719$ \\
\hline $\begin{array}{l}\text { X-Men: The Last } \\
\text { Stand }\end{array}$ & May 26, 2006 & $\$ 210$ million & $\$ 234,362,462$ & $\$ 224,997,093$ & $\$ 459,359,555$ \\
\hline Ghost Rider & February 16, 2007 & $\$ 110$ million & $\$ 115,802,596$ & $\$ 112,935,797$ & $\$ 228,738,393$ \\
\hline Spider-Man 3 & May 4, 2007 & $\$ 258$ million & $\$ 336,530,303$ & $\$ 554,341,323$ & $\$ 890,871,626$ \\
\hline $\begin{array}{l}\text { Fantastic Four: Rise of } \\
\text { the Silver Surfer }\end{array}$ & June 15, 2007 & $\$ 130$ million & $\$ 131,921,738$ & $\$ 157,126,025$ & $\$ 289,047,763$ \\
\hline
\end{tabular}

The information used from the above table was drawn from Box Office Mojo.

Accessed October 16, 2014.

\section{Appendix C}

$\underline{\text { Sony/Columbia Pictures Films }}$

\begin{tabular}{|c|c|c|c|c|c|c|c|c|}
\hline $\begin{array}{l}\text { Title of } \\
\text { Film }\end{array}$ & $\begin{array}{c}\text { Release } \\
\text { Date }\end{array}$ & Budget & $\begin{array}{c}\text { Domestic Box } \\
\text { Office }\end{array}$ & $\begin{array}{c}\text { Foreign Box } \\
\text { Office }\end{array}$ & $\begin{array}{l}\text { Total Box } \\
\text { Office }\end{array}$ & IMDB Score & $\begin{array}{c}\text { Rotten } \\
\text { Tomatoes } \\
\text { Score }\end{array}$ & $\begin{array}{c}\text { Metacritic } \\
\text { Score }\end{array}$ \\
\hline $\begin{array}{l}\text { Spider- } \\
\text { Man }\end{array}$ & $\begin{array}{l}\text { May 3, } \\
2002\end{array}$ & $\$ 139$ million & $\$ 403,706,375$ & $\$ 418,002,176$ & $\$ 821,708,551$ & 7.3 & $89 \%$ & 73 \\
\hline $\begin{array}{l}\text { Spider- } \\
\text { Man } 2\end{array}$ & $\begin{array}{l}\text { June } 30, \\
2004\end{array}$ & $\$ 200$ million & $\$ 373,585,825$ & $\$ 410,180,516$ & $\$ 783,766,341$ & 7.4 & $94 \%$ & 83 \\
\hline $\begin{array}{l}\text { Spider- } \\
\text { Man } 3\end{array}$ & $\begin{array}{l}\text { May 4, } \\
2007\end{array}$ & $\$ 258$ million & $\$ 336,530,303$ & $\$ 554,341,323$ & $\$ 890,871,626$ & 6.2 & $63 \%$ & 59 \\
\hline $\begin{array}{l}\text { The } \\
\text { Amazing } \\
\text { Spider- } \\
\text { Man }\end{array}$ & $\begin{array}{l}\text { July } 3, \\
2012\end{array}$ & $\$ 230$ million & $\$ 262,030,663$ & $\$ 495,900,000$ & $\$ 757,930,663$ & 7.1 & $73 \%$ & 66 \\
\hline $\begin{array}{l}\text { The } \\
\text { Amazing } \\
\text { Spider- } \\
\text { Man } 2\end{array}$ & $\begin{array}{l}\text { May 2, } \\
2014\end{array}$ & $\$ 200$ million & $\$ 202,853,933$ & $\$ 506,128,390$ & $\$ 708,982,323$ & 6.9 & $53 \%$ & 53 \\
\hline
\end{tabular}

The information used from the above table was drawn from Box Office Mojo, IMDB, Rotten Tomatoes and Metacritic.

Accessed October 16, 2014. 
Appendix D

$20^{\text {th }}$ Century Fox Pictures Films

\begin{tabular}{|c|c|c|c|c|c|c|c|c|}
\hline Title of Film & Release Date & Budget & $\begin{array}{l}\text { Domestic Box } \\
\text { Office }\end{array}$ & $\begin{array}{l}\text { Foreign Box } \\
\text { Office }\end{array}$ & $\begin{array}{l}\text { Total Box } \\
\text { Office }\end{array}$ & $\begin{array}{l}\text { IMDB } \\
\text { Score }\end{array}$ & $\begin{array}{c}\text { Rotten } \\
\text { Tomatoes } \\
\text { Score }\end{array}$ & $\begin{array}{c}\text { Metacritic } \\
\text { Score }\end{array}$ \\
\hline X-Men & July 14,2000 & $\$ 75$ million & $\$ 157,299,171$ & $\$ 139,039,810$ & $\$ 296,339,527$ & 7.4 & $82 \%$ & 64 \\
\hline Daredevil & $\begin{array}{l}\text { February 14, } \\
2003\end{array}$ & $\$ 78$ million & $\$ 102,543,518$ & $\$ 76,636,200$ & $\$ 179,179,718$ & 5.4 & $10 \%$ & 42 \\
\hline $\begin{array}{l}\text { X2: X-Men } \\
\text { United }\end{array}$ & May 2, 3003 & $\$ 110$ million & $\$ 214,949,694$ & $\$ 192,761,855$ & $\$ 407,711,549$ & 7.5 & $87 \%$ & 68 \\
\hline Elektra & $\begin{array}{l}\text { January 14, } \\
2005\end{array}$ & $\$ 43$ million & $\$ 24,409,722$ & $\$ 32,271,844$ & $\$ 56,681,566$ & 4.8 & $45 \%$ & 34 \\
\hline Fantastic Four & July 8, 2005 & $\$ 100$ million & $\$ 154,696,080$ & $\$ 175,883,639$ & $\$ 330,579,719$ & 5.7 & $27 \%$ & 40 \\
\hline $\begin{array}{l}\text { X-Men: The } \\
\text { Last Stand }\end{array}$ & May 26, 2006 & $\$ 210$ million & $\$ 234,362,462$ & $\$ 224,997,093$ & $\$ 459,359,555$ & 6.8 & $58 \%$ & 58 \\
\hline $\begin{array}{l}\text { Fantastic Four: } \\
\text { Rise of the } \\
\text { Silver Surfer }\end{array}$ & June 15,2007 & $\$ 130$ million & $\$ 131,921,738$ & $\$ 157,126,025$ & $\$ 289,047,763$ & 5.6 & $37 \%$ & 45 \\
\hline $\begin{array}{l}\text { X-Men } \\
\text { Origins: } \\
\text { Wolverine }\end{array}$ & May 1,2009 & $\$ 150$ million & $\$ 179,833,157$ & $\$ 193,179,707$ & $\$ 373,062,864$ & 6.7 & $38 \%$ & 40 \\
\hline $\begin{array}{l}\text { X-Men: First } \\
\text { Class }\end{array}$ & June 3, 2011 & $\$ 160$ million & $\$ 146,408,305$ & $\$ 207,215,819$ & $\$ 353,624,124$ & 7.8 & $87 \%$ & 65 \\
\hline The Wolverine & July 25,2013 & $\$ 120$ million & $\$ 132,556,852$ & $\$ 282,271,394$ & $\$ 414,828,246$ & 6.7 & $69 \%$ & 60 \\
\hline $\begin{array}{l}\text { X-Men: Days } \\
\text { of Future Past }\end{array}$ & May 23, 2014 & $\$ 200$ million & $\$ 233,921,534$ & $\$ 512,124,166$ & $\$ 746,045,700$ & 8.1 & $91 \%$ & 74 \\
\hline
\end{tabular}

The information used from the above table was drawn from Box Office Mojo, IMDB, Rotten Tomatoes and Metacritic. Accessed October 16, 2014

\section{Appendix E}

$\underline{\text { Secondary Marvel Films Post-2008 }}$

\begin{tabular}{|c|c|c|c|c|c|c|c|c|}
\hline Title of Film & $\begin{array}{l}\text { Release } \\
\text { Date }\end{array}$ & Budget & $\begin{array}{l}\text { Domestic Box } \\
\text { Office }\end{array}$ & $\begin{array}{l}\text { Foreign Box } \\
\text { Office }\end{array}$ & $\begin{array}{l}\text { Total Box } \\
\text { Office }\end{array}$ & $\begin{array}{l}\text { IMDB } \\
\text { Score }\end{array}$ & $\begin{array}{l}\text { Rotten } \\
\text { Tomatoes } \\
\text { Score }\end{array}$ & $\begin{array}{l}\text { Metacritic } \\
\text { Score }\end{array}$ \\
\hline Punisher: War Zone & $\begin{array}{l}\text { December } \\
5,2008\end{array}$ & $\begin{array}{l}\$ 35 \\
\text { million }\end{array}$ & $\$ 8,050,977$ & $\$ 2,049,059$ & $\$ 10,100,036$ & 6.0 & $27 \%$ & 30 \\
\hline $\begin{array}{l}\text { Ghost Rider: Spirit } \\
\text { of Vengeance }\end{array}$ & $\begin{array}{l}\text { February } \\
17,2012\end{array}$ & $\begin{array}{l}\$ 57 \\
\text { million }\end{array}$ & $\$ 51,774,002$ & $\$ 80,789,928$ & $\$ 132,563,930$ & 4.3 & $18 \%$ & 32 \\
\hline
\end{tabular}

The information used from the above table was drawn from Box Office Mojo, IMDB, Rotten Tomatoes and Metacritic. Accessed October 16, 2014. 


\section{Appendix F}

DC Comics/DC Comics Vertigo Imprint Productions Released Post-2000

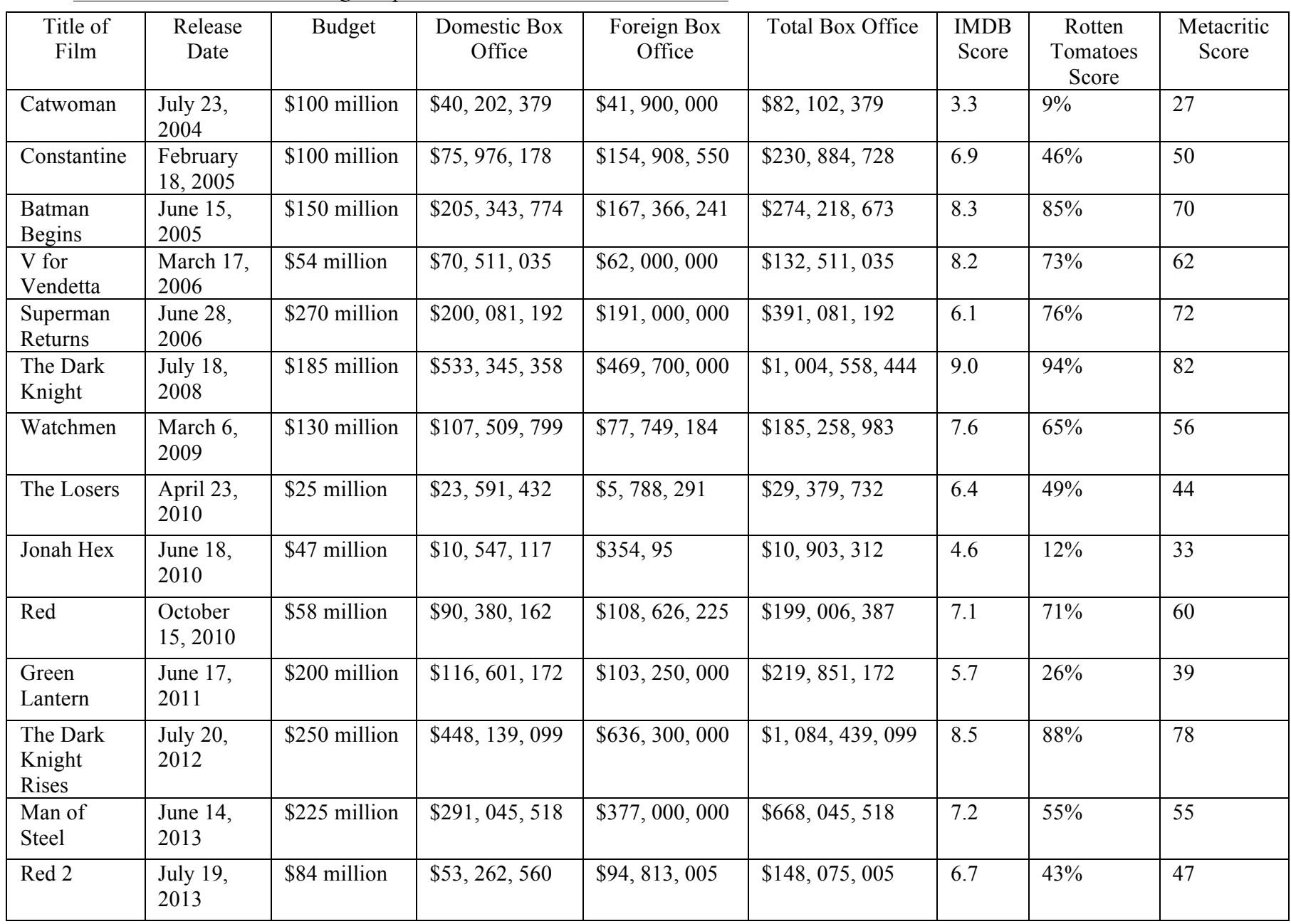

The information used from the above table was drawn from Box Office Mojo, IMDB, Rotten Tomatoes and Metacritic.

Accessed October 16, 2014 
$\underline{\text { Appendix G }}$

Marvel Studios Films/Marvel Cinematic Universe Films

\begin{tabular}{|c|c|c|c|c|c|c|c|c|}
\hline Title of Film & Release Date & Budget & $\begin{array}{c}\text { Domestic Box } \\
\text { Office }\end{array}$ & $\begin{array}{c}\text { Foreign Box } \\
\text { Office }\end{array}$ & $\begin{array}{l}\text { Total Box } \\
\text { Office }\end{array}$ & $\begin{array}{l}\text { IMDB } \\
\text { Score }\end{array}$ & $\begin{array}{c}\text { Rotten } \\
\text { Tomatoes } \\
\text { Score }\end{array}$ & $\begin{array}{l}\text { Metacritic } \\
\text { Score }\end{array}$ \\
\hline Iron Man & May 2, 2008 & $\$ 140$ million & $\$ 318,412,101$ & $\$ 266,762,121$ & $\$ 545,174,222$ & 7.1 & $93 \%$ & 79 \\
\hline $\begin{array}{l}\text { The } \\
\text { Incredible } \\
\text { Hulk }\end{array}$ & $\begin{array}{l}\text { June } 13, \\
2008\end{array}$ & $\$ 150$ million & $\$ 134,806,913$ & $\$ 128,620,638$ & $\$ 263,427,551$ & 6.9 & $67 \%$ & 61 \\
\hline Iron Man 2 & May 7,2010 & $\$ 200$ million & $\$ 312,433,331$ & $\$ 311,500,000$ & $\$ 623,933,331$ & 7.2 & $73 \%$ & 57 \\
\hline Thor & May 6, 2011 & $\$ 150$ million & $\$ 181,030,624$ & $\$ 268,295,994$ & $\$ 449,326,618$ & 7.0 & $77 \%$ & 57 \\
\hline $\begin{array}{l}\text { Captain } \\
\text { America: } \\
\text { The First } \\
\text { Avenger }\end{array}$ & $\begin{array}{l}\text { July } 22, \\
2011\end{array}$ & $\$ 140$ million & $\$ 176,654,505$ & $\$ 193,915,269$ & $\$ 370,569,774$ & 6.8 & $79 \%$ & 66 \\
\hline $\begin{array}{l}\text { Marvel's } \\
\text { The } \\
\text { Avengers }\end{array}$ & May 4, 2012 & $\$ 220$ million & $\$ 623,357,910$ & $\$ 895,237,000$ & $\begin{array}{l}\$ 1,518,594, \\
910\end{array}$ & 8.2 & $92 \%$ & 69 \\
\hline Iron Man 3 & May 3, 2013 & $\$ 200$ million & $\$ 409,013,994$ & $\$ 806,426,000$ & $\begin{array}{l}\$ 1,215,439, \\
994\end{array}$ & 7.3 & $79 \%$ & 62 \\
\hline $\begin{array}{l}\text { Thor: The } \\
\text { Dark World }\end{array}$ & $\begin{array}{l}\text { November } 8 \text {, } \\
2013\end{array}$ & $\$ 170$ million & $\$ 206,362,140$ & $\$ 438,421,000$ & $\$ 664,783,140$ & 7.2 & $66 \%$ & 54 \\
\hline $\begin{array}{l}\text { Captain } \\
\text { America: } \\
\text { The Winter } \\
\text { Soldier }\end{array}$ & April 4, 2014 & $\$ 170$ million & $\$ 259,766,572$ & $\$ 454,317,000$ & $\$ 714,083,572$ & 7.8 & $89 \%$ & 70 \\
\hline $\begin{array}{l}\text { Guardians of } \\
\text { the Galaxy }\end{array}$ & $\begin{array}{l}\text { August 1, } \\
2014\end{array}$ & $\$ 170$ million & $\$ 333,079,971$ & $\$ 439,600,000$ & $\$ 772,679,971$ & 8.2 & $91 \%$ & 76 \\
\hline
\end{tabular}

The information used from the above table was drawn from Box Office Mojo, IMDB, Rotten Tomatoes and Metacritic. Accessed October 16, 2014.

\section{Appendix H}

Profit - Marvel, MCU

\begin{tabular}{|l|l|l|}
\hline & Total Domestic Box Office Gross & Total Worldwide Box Office Gross \\
\hline $\begin{array}{l}\text { Marvel Cinematic } \\
\text { Universe Films } \\
\text { (Marvel Studios) }\end{array}$ & $\$ 2,954,918,061$ & $\$ 7,158,012,578$ \\
\hline $\begin{array}{l}\text { Spider-Man Universe } \\
\text { (Original and Reboot) }\end{array}$ & $\$ 1,578,707,099$ & $\$ 3,963,259,504$ \\
\hline X-Men Universe & $\$ 1,299,381,721$ & $\$ 3,050,971,565$ \\
\hline
\end{tabular}

The information used from the above table was drawn from Box Office Mojo.

Accessed October 16, 2014. 


\section{Appendix I}

Major Marvel Characters

\begin{tabular}{|c|c|c|}
\hline Marvel Characters & Creator & First Appearance \\
\hline The Avengers & $\begin{array}{l}\text { Stan Lee } \\
\text { Jack Kirby }\end{array}$ & The Avengers \#1 (September 1963) \\
\hline Captain America & $\begin{array}{l}\text { Joe Simon } \\
\text { Jack Kirby }\end{array}$ & Captain America Comics \#1 (March 1941) \\
\hline Iron Man & $\begin{array}{l}\text { Stan Lee } \\
\text { Jack Kirby } \\
\text { Larry Lieber } \\
\text { Don Heck } \\
\end{array}$ & Tales of Suspense \#39 (March 1963) \\
\hline Thor & $\begin{array}{l}\text { Stan Lee } \\
\text { Jack Kirby } \\
\text { Larry Lieber }\end{array}$ & Journey into Mystery \#83 (August 1962) \\
\hline Loki & $\begin{array}{l}\text { Stan Lee } \\
\text { Jack Kirby } \\
\text { Larry Lieber }\end{array}$ & $\begin{array}{l}\text { Historical: Venus \#6 (August 1949) } \\
\text { Modern day: Journey into Mystery No. } 85 \text { (October } \\
\text { 1962) }\end{array}$ \\
\hline Black Widow & $\begin{array}{l}\text { Stan Lee } \\
\text { Don Heck } \\
\text { Don Rico }\end{array}$ & Tales of Suspense \#52 (April 1964) \\
\hline Hawkeye & $\begin{array}{l}\text { Stan Lee } \\
\text { Don Heck }\end{array}$ & Tales of Suspense \#57 (Sept. 1964) \\
\hline The Hulk & $\begin{array}{l}\text { Stan Lee } \\
\text { Jack Kirby }\end{array}$ & The Incredible Hulk \#1 (May 1962) \\
\hline Ant-Man I (Hank Pym) & $\begin{array}{l}\text { Stan Lee } \\
\text { Jack Kirby } \\
\text { Larry Lieber }\end{array}$ & Tales to Astonish \#27 (January 1962) \\
\hline Ant-Man II (Scott Lang) & $\begin{array}{l}\text { David Michelinie } \\
\text { John Byrne }\end{array}$ & $\begin{array}{l}\text { As Scott Lang: Avengers \#181 (March 1979) } \\
\text { As Ant-Man: Marvel Premiere \#47 (April 1979) }\end{array}$ \\
\hline The Wasp & $\begin{array}{l}\text { Stan Lee } \\
\text { Jack Kirby }\end{array}$ & Tales to Astonish \#44 (June 1963) \\
\hline The Vision & $\begin{array}{l}\text { Stan Lee } \\
\text { Roy Thomas } \\
\text { John Buscema } \\
\end{array}$ & $\begin{array}{l}\text { The Avengers \#57 } \\
\text { (October 1968) }\end{array}$ \\
\hline Nick Fury & $\begin{array}{l}\text { Stan Lee } \\
\text { Jack Kirby }\end{array}$ & $\begin{array}{l}\text { Sgt. Fury and His Howling Commandos \#1 (May } \\
\text { 1963) }\end{array}$ \\
\hline Captain Marvel (Mar-Vell) & $\begin{array}{l}\text { Stan Lee } \\
\text { Gene Colan }\end{array}$ & Marvel Super-Heroes \#12 (December 1967) \\
\hline Ms. Marvel/Captain Marvel (Carol Danvers) & $\begin{array}{l}\text { Roy Thomas } \\
\text { Gene Colan }\end{array}$ & $\begin{array}{l}\text { As Carol Danvers: } \\
\text { Marvel Super-Heroes \#13 (March 1968) } \\
\text { As Ms. Marvel: } \\
\text { Ms. Marvel \#1 (January 1977) }\end{array}$ \\
\hline She-Hulk & $\begin{array}{l}\text { Stan Lee } \\
\text { John Buscema }\end{array}$ & Savage She-Hulk \#1 (February 1980) \\
\hline Mockingbird & $\begin{array}{l}\text { Len Wein } \\
\text { Neil Adams }\end{array}$ & Marvel Team-Up \#95 (July, 1980) \\
\hline Wonder Man & $\begin{array}{l}\text { Stan Lee } \\
\text { Jack Kirby }\end{array}$ & Avengers \#9 (Oct. 1964) \\
\hline Bucky Barnes/The Winter Soldier & $\begin{array}{l}\text { Bucky: Joe Simon, Stan Lee } \\
\text { Winter Soldier: Ed Brubaker, } \\
\text { Steve Epting }\end{array}$ & $\begin{array}{l}\text { As Bucky: Captain America Comics \#1 (March } \\
\text { 1941) } \\
\text { As Winter Soldier: Captain America \#1 (Jan. 2005) }\end{array}$ \\
\hline Fantastic Four (Group) & $\begin{array}{l}\text { Stan Lee } \\
\text { Jack Kirby }\end{array}$ & The Fantastic Four \#1 (November 1961) \\
\hline Fantastic Four - Mr. Fantastic & $\begin{array}{l}\text { Stan Lee } \\
\text { Jack Kirby }\end{array}$ & The Fantastic Four \#1 (Nov. 1961) \\
\hline Fantastic Four - Invisible Woman & Stan Lee & The Fantastic Four \#1 (Nov. 1961) \\
\hline
\end{tabular}




\begin{tabular}{|c|c|c|}
\hline & Jack Kirby & \\
\hline Fantastic Four - The Human Torch (Johnny Storm) & $\begin{array}{l}\text { Stan Lee } \\
\text { Jack Kirby }\end{array}$ & The Fantastic Four \#1 (Nov. 1961) \\
\hline Fantastic Four - The Thing & $\begin{array}{l}\text { Stan Lee } \\
\text { Jack Kirby }\end{array}$ & The Fantastic Four \#1 (Nov. 1961) \\
\hline Doctor Doom & $\begin{array}{l}\text { Stan Lee } \\
\text { Jack Kirby }\end{array}$ & The Fantastic Four \#5 (July 1962) \\
\hline Silver Surfer & $\begin{array}{l}\text { Stan Lee } \\
\text { Jack Kirby }\end{array}$ & The Fantastic Four \#48 (March 1966) \\
\hline Galactus & $\begin{array}{l}\text { Stan Lee } \\
\text { Jack Kirby }\end{array}$ & Fantastic Four \#48 (March 1966) \\
\hline The Skrulls & $\begin{array}{l}\text { Stan Lee } \\
\text { Jack Kirby }\end{array}$ & Fantastic Four \#2 (January 1962) \\
\hline The Badoon & $\begin{array}{l}\text { Stan Lee } \\
\text { John Buscema }\end{array}$ & Silver Surfer vol. 1, \#2 (October 1968) \\
\hline Spiderman & $\begin{array}{l}\text { Stan Lee } \\
\text { Steve Ditko }\end{array}$ & Amazing Fantasy \#15 (Aug. 1962) \\
\hline The Green Goblin & $\begin{array}{l}\text { Stan Lee } \\
\text { Steve Ditko }\end{array}$ & The Amazing Spider-Man \#14 (July 1964) \\
\hline Gwen Stacy & $\begin{array}{l}\text { Stan Lee } \\
\text { Steve Ditko }\end{array}$ & The Amazing Spider-Man \#31 (December 1965) \\
\hline Mary Jane Watson & $\begin{array}{l}\text { Stan Lee } \\
\text { Steve Ditko } \\
\text { John Romita Sr. }\end{array}$ & $\begin{array}{l}\text { (Partial) The Amazing Spider-Man \#25 (June 1965) } \\
\text { (Full) The Amazing Spider-Man \#42 (November } \\
\text { 1966) }\end{array}$ \\
\hline Norman Osborn & $\begin{array}{l}\text { Stan Lee } \\
\text { Steve Ditko }\end{array}$ & $\begin{array}{l}\text { As Green Goblin: The Amazing Spider-Man \#14 } \\
\text { (July 1964) } \\
\text { Named as Norman Osborn: The Amazing Spider- } \\
\text { Man \#37 (June 1966) }\end{array}$ \\
\hline Harry Osborn & $\begin{array}{l}\text { Stan Lee } \\
\text { Steve Ditko }\end{array}$ & $\begin{array}{l}\text { As Harry Osborn: } \\
\text { The Amazing Spider-Man \#31 (December 1965) }\end{array}$ \\
\hline Venom & $\begin{array}{l}\text { Randy Schueller (original } \\
\text { idea) } \\
\text { David Michelinie } \\
\text { Mike Zeck (alien costume } \\
\text { design) } \\
\text { Todd McFarlane } \\
\end{array}$ & $\begin{array}{l}\text { As "The Alien Costume": The Amazing Spider- } \\
\text { Man \#252 (May 1984) } \\
\text { Symbiote Origin Story: Secret Wars \#8 (December } \\
\text { 1984) } \\
\text { As Venom: The Amazing Spider-Man \#299 (April } \\
\text { 1988) }\end{array}$ \\
\hline Thanos & Jim Starlin & Iron Man \#55 (February 1973) \\
\hline Ultron & $\begin{array}{l}\text { Roy Thomas } \\
\text { John Buscema }\end{array}$ & $\begin{array}{l}\text { Avengers \#54 (July 1968) - cameo } \\
\text { Avengers \#55 (August 1968) - first appearance }\end{array}$ \\
\hline Guardians of the Galaxy (Group) & $\begin{array}{l}\text { Original: Arnold Drake, Gene } \\
\text { Colan } \\
\text { Modern: Dan Abnett, Andy } \\
\text { Lanning }\end{array}$ & $\begin{array}{l}\text { Original: } 1969 \\
\text { Modern: Guardians of the Galaxy \#1 (May 2008) }\end{array}$ \\
\hline Guardians of the Galaxy - Rocket Raccoon & $\begin{array}{l}\text { Bill Mantlo } \\
\text { Keith Giffen }\end{array}$ & Marvel Preview \#7 (Summer 1976) \\
\hline Guardians of the Galaxy - Groot & $\begin{array}{l}\text { Stan Lee } \\
\text { Jack Kirby } \\
\text { Dick Ayers }\end{array}$ & Tales to Astonish \#13 (November 1960) \\
\hline Guardians of the Galaxy - Peter Quill/Starlord & $\begin{array}{l}\text { Steve Englehart } \\
\text { Steve Gan }\end{array}$ & Marvel Preview \#4 (January 1976) \\
\hline Guardians of the Galaxy - Gamora & Jim Starlin & Strange Tales \#180 (June 1975) \\
\hline Guardians of the Galaxy - Drax the Destroyer & $\begin{array}{l}\text { Mike Friedrick } \\
\text { Jim Starlin }\end{array}$ & Iron Man \#55 (February 1973) \\
\hline The Kree & $\begin{array}{l}\text { Stan Lee } \\
\text { Jack Kirby }\end{array}$ & Fantastic Four \#65 (August 1967) \\
\hline The Inhumans et al. & $\begin{array}{l}\text { Stan Lee } \\
\text { Jack Kirby }\end{array}$ & Fantastic Four \#45 (December 1965) \\
\hline
\end{tabular}




\begin{tabular}{|c|c|c|}
\hline Daredevil & $\begin{array}{l}\text { Stan Lee } \\
\text { Bill Everett }\end{array}$ & Daredevil \#1 (April 1964) \\
\hline Electra & Frank Miller & Daredevil \#168 (January 1981) \\
\hline Doctor Strange & Steve Ditko & Strange Tales \#110 (July 1963) \\
\hline Luke Cage & $\begin{array}{l}\text { Archie Goodwin } \\
\text { John Romita, Sr. }\end{array}$ & Luke Cage, Hero For Hire \#1 (June 1972) \\
\hline Power Pack & $\begin{array}{l}\text { Louise Simonson } \\
\text { June Brigman }\end{array}$ & $\begin{array}{l}\text { Power Pack \#1 (May } 1984 \text { release; August } 1984 \\
\text { cover) }\end{array}$ \\
\hline Ghost Rider & $\begin{array}{l}\text { Gary Friedrich } \\
\text { Roy Thomas } \\
\text { Mike Ploog }\end{array}$ & Marvel Spotlight \#5 (Aug. 1972) \\
\hline Cloak and Dagger & $\begin{array}{l}\text { Bill Mantlo } \\
\text { Ed Hannigan }\end{array}$ & $\begin{array}{l}\text { Peter Parker, the Spectacular Spider-Man \#64 } \\
\text { (March 1982) }\end{array}$ \\
\hline Jessica Jones & $\begin{array}{l}\text { Brian Michael Bendis } \\
\text { Michael Gaydos }\end{array}$ & Alias \#1 (November 2001) \\
\hline Iron Fist & $\begin{array}{l}\text { Roy Thomas } \\
\text { Gil Kane }\end{array}$ & Marvel Premiere \#15 (May 1974) \\
\hline The Defenders & $\begin{array}{l}\text { Roy Thomas } \\
\text { Ross Andru }\end{array}$ & Marvel Feature \#1 (December 1971) \\
\hline Black Panther & $\begin{array}{l}\text { Stan Lee } \\
\text { Jack Kirby }\end{array}$ & Fantastic Four \#52 (July 1966) \\
\hline Scarlet Witch & $\begin{array}{l}\text { Stan Lee } \\
\text { Jack Kirby }\end{array}$ & The X-Men \#4 (March 1964) \\
\hline Quicksilver & $\begin{array}{l}\text { Stan Lee } \\
\text { Jack Kirby }\end{array}$ & The X-Men \#4 (March 1964) \\
\hline The Human Torch (Andriod) & Carl Burgos & Marvel Comics \#1 (Oct. 1939) \\
\hline Namor the Sub-Mariner & Bill Everett & Motion Picture Funnies Weekly (April 1939) \\
\hline X-Men (Group) & $\begin{array}{l}\text { Stan Lee } \\
\text { Jack Kirby }\end{array}$ & The X-Men \#1 (September 10, 1963) \\
\hline X-Men - Charles Xavier/Professor X & $\begin{array}{l}\text { Stan Lee } \\
\text { Jack Kirby }\end{array}$ & The X-Men \#1 (September 1963) \\
\hline X-Men - Magneto & $\begin{array}{l}\text { Stan Lee } \\
\text { Jack Kirby }\end{array}$ & The X-Men \#1 (September 1963) \\
\hline X-Men - Cyclops & $\begin{array}{l}\text { Stan Lee } \\
\text { Jack Kirby }\end{array}$ & The X-Men \#1 (September 1963) \\
\hline X-Men - Jean Grey/Phoenix/Marvel Girl & $\begin{array}{l}\text { Stan Lee } \\
\text { Jack Kirby }\end{array}$ & The X-Men \#1 (September 1963) \\
\hline X-Men - Angel & $\begin{array}{l}\text { Stan Lee } \\
\text { Jack Kirby }\end{array}$ & The X-Men \#1 (September 1963) \\
\hline X-Men - Beast/Hank McCoy & $\begin{array}{l}\text { Stan Lee } \\
\text { Jack Kirby }\end{array}$ & The X-Men \#1 (September 1963) \\
\hline X-Men - Iceman & $\begin{array}{l}\text { Stan Lee } \\
\text { Jack Kirby }\end{array}$ & The X-Men \#1 (September 1963) \\
\hline X-Men - Storm & $\begin{array}{l}\text { Len Wein } \\
\text { Dave Cockrum }\end{array}$ & $\begin{array}{l}\text { Giant-Size X-Men \#1 } \\
\text { (May 1975) }\end{array}$ \\
\hline X-Men - Nightcrawler & $\begin{array}{l}\text { Len Wein } \\
\text { Dave Cockrum }\end{array}$ & Giant-Size X-Men \#1 (May 1975) \\
\hline X-Men - Colossus & $\begin{array}{l}\text { Len Wein } \\
\text { Dave Cockrum }\end{array}$ & Giant-Size X-Men \#1 (May 1975) \\
\hline X-Men - Kitty Pryde/Shadowcat & $\begin{array}{l}\text { Chris Claremont } \\
\text { John Byrne }\end{array}$ & Uncanny X-Men \#129 (January 1980) \\
\hline X-Men - Rogue & $\begin{array}{l}\text { Chris Claremont } \\
\text { Michael Golden }\end{array}$ & Avengers Annual \#10 (November 1981) \\
\hline X-Men - Gambit & $\begin{array}{l}\text { Chris Claremont } \\
\text { Jim Lee }\end{array}$ & $\begin{array}{l}\text { Cameo: Uncanny X-Men Annual \#14 (July 1990) } \\
\text { Full: Uncanny X-Men \#266 (August 1990) }\end{array}$ \\
\hline
\end{tabular}




\begin{tabular}{|c|c|c|}
\hline X-Men - Jubilee & $\begin{array}{l}\text { Chris Claremont } \\
\text { Marc Silvestri }\end{array}$ & Uncanny X-Men \#244 (May, 1989) \\
\hline X-Men - Emma Frost & $\begin{array}{l}\text { Chris Claremont } \\
\text { John Byrne }\end{array}$ & Uncanny X-Men \#129 (January 1980) \\
\hline X-Men - Mystique & $\begin{array}{l}\text { Dave Cockrum } \\
\text { Chris Claremont }\end{array}$ & $\begin{array}{l}\text { Actual: Ms. Marvel No.16 (May 1978) } \\
\text { Full: Ms. Marvel No.17 (June 1978) }\end{array}$ \\
\hline X-Men - Wolverine & $\begin{array}{l}\text { Roy Thomas } \\
\text { Len Wein } \\
\text { John Romita, Sr. }\end{array}$ & $\begin{array}{l}\text { Cameo: The Incredible Hulk \#180 (October 1974) } \\
\text { Full: The Incredible Hulk \#181 (November 1974) }\end{array}$ \\
\hline X-Men - Deadpool & $\begin{array}{l}\text { Fabian Nicieza } \\
\text { Rob Liefeld }\end{array}$ & New Mutants \#98 (February 1991) \\
\hline X-Men - Polaris & $\begin{array}{l}\text { Arnold Drake } \\
\text { Don Heck } \\
\text { Werner Roth } \\
\text { Jim Steranko }\end{array}$ & The X-Men \#49 (October, 1968) \\
\hline X-Men - Cable & $\begin{array}{l}\text { As Nathan Summers: Chris } \\
\text { Claremont, Rick Leonardi } \\
\text { As Cable: Louise Simonson, } \\
\text { Rob Liefeld }\end{array}$ & $\begin{array}{l}\text { As Nathan Summers: Uncanny X-Men \#201 } \\
\text { (January 1986) } \\
\text { As Cable: New Mutants \#87 (March 1990) }\end{array}$ \\
\hline
\end{tabular}

The information used from the above table was drawn from the Marvel Comics Database. Accessed October 16, 2014. 
$\underline{\text { Appendix J }}$

Marvel Ownership: Past Film Studio Owners of Marvel Comics Film Character Rights - 2008

\begin{tabular}{|c|c|c|c|c|c|c|}
\hline Marvel Studios & Sony & $\begin{array}{l}20^{\text {th }} \text { Century } \\
\text { Fox }\end{array}$ & Universal & Lionsgate & $\begin{array}{l}\text { Artisan } \\
\text { Entertainment }\end{array}$ & $\begin{array}{l}\text { New Line } \\
\text { Cinema }\end{array}$ \\
\hline Captain America & $\begin{array}{l}\text { Spiderman et. } \\
\text { al. }\end{array}$ & $\begin{array}{l}\text { X-Men et. } \\
\text { al. }\end{array}$ & The Hulk & $\begin{array}{l}\text { The } \\
\text { Punisher }\end{array}$ & Luke Cage & Blade \\
\hline Iron Man & Ghost Rider & $\begin{array}{l}\text { Fantastic } \\
\text { Four et. al. } \\
\text { (Silver } \\
\text { Surfer, the } \\
\text { Skrulls, the } \\
\text { Badoon) } \\
\end{array}$ & & Man-Thing & & \\
\hline Thor & & Daredevil & & & & \\
\hline Black Widow & & Elektra & & & & \\
\hline Hawkeye & & $\begin{array}{l}\text { Scarlet } \\
\text { Witch and } \\
\text { Quicksilver } \\
\text { - SHARED } \\
\text { WITH } \\
\text { MARVEL }\end{array}$ & & & & \\
\hline \multicolumn{7}{|l|}{ Doctor Strange } \\
\hline \multicolumn{7}{|l|}{ Ant-Man } \\
\hline \multicolumn{7}{|l|}{ Wasp } \\
\hline \multicolumn{7}{|l|}{ Black Panther } \\
\hline \multicolumn{7}{|l|}{ The Kree } \\
\hline \multicolumn{7}{|l|}{ Captain Marvel } \\
\hline \multicolumn{7}{|l|}{ Inhumans } \\
\hline \multicolumn{7}{|l|}{$\begin{array}{l}\text { Scarlet Witch and } \\
\text { Quicksilver - } \\
\text { SHARED WITH } \\
\text { FOX }\end{array}$} \\
\hline ETC. & & & & & & \\
\hline
\end{tabular}

The information used from the above table was drawn from Carl Lee's Screenrant article, "Which Studios Own Which Marvel Characters."

Accessed October 16, 2014. 


\section{Appendix K}

Marvel Ownership: Current Ownership of Marvel Comics Film Character Rights Regarding Film - 2015

\begin{tabular}{|c|c|c|c|}
\hline Marvel Studios & $20^{\text {th }}$ Century Fox & Sony & Universal Pictures \\
\hline Captain America & X-Men et. al. & $\begin{array}{l}\text { Spiderman et. al. - } \\
\text { SHARED WITH } \\
\text { MARVEL }\end{array}$ & Namor the Sub-Mariner \\
\hline Iron Man & $\begin{array}{l}\text { Fantastic Four et. al. (Silver } \\
\text { Surfer, the Skrulls, the } \\
\text { Badoon) }\end{array}$ & & \\
\hline Thor & $\begin{array}{l}\text { Scarlet Witch and } \\
\text { Quicksilver - SHARED } \\
\text { WITH MARVEL }\end{array}$ & & \\
\hline \multicolumn{4}{|l|}{ Black Widow } \\
\hline \multicolumn{4}{|l|}{ Hawkeye } \\
\hline \multicolumn{4}{|l|}{ The Hulk } \\
\hline \multicolumn{4}{|l|}{ Doctor Strange } \\
\hline \multicolumn{4}{|l|}{ Ant-Man } \\
\hline \multicolumn{4}{|l|}{ Wasp } \\
\hline \multicolumn{4}{|l|}{ Black Panther } \\
\hline \multicolumn{4}{|l|}{ The Kree } \\
\hline \multicolumn{4}{|l|}{ Captain Marvel } \\
\hline \multicolumn{4}{|l|}{ Inhumans } \\
\hline \multicolumn{4}{|l|}{ Daredevil } \\
\hline \multicolumn{4}{|l|}{ Elektra } \\
\hline \multicolumn{4}{|l|}{ The Punisher } \\
\hline \multicolumn{4}{|l|}{ Luke Cage } \\
\hline \multicolumn{4}{|l|}{ Blade } \\
\hline \multicolumn{4}{|l|}{ Iron Fist } \\
\hline \multicolumn{4}{|l|}{$\begin{array}{l}\text { Scarlet Witch and } \\
\text { Quicksilver - SHARED } \\
\text { WITH FOX }\end{array}$} \\
\hline \multicolumn{4}{|l|}{$\begin{array}{l}\text { Spiderman et. al. - } \\
\text { SHARED WITH } \\
\text { MARVEL }\end{array}$} \\
\hline ETC. & & & \\
\hline
\end{tabular}

The information used from the above table was drawn from Carl Lee's Screenrant article, "Which Studios Own Which Marvel Characters."

Accessed October 16, 2014. 


\section{Appendix L}

$\underline{\text { Marvel Cinematic Universe - Films }}$

\begin{tabular}{|l|l|l|}
\hline \multicolumn{1}{|c|}{ Phase One } & \multicolumn{1}{|c|}{ Phase Two } & \multicolumn{1}{|c|}{ Phase Three } \\
\hline $\begin{array}{l}\text { Iron Man - May 2, } 2008 \text { (dir. Jon } \\
\text { Favreau) }\end{array}$ & $\begin{array}{l}\text { Iron Man 3 - May 3, 2013 (dir. } \\
\text { Shane Black) }\end{array}$ & $\begin{array}{l}\text { Captain America: Civil War - May } \\
\text { 6, 2016 (dir. Anthony and Joe } \\
\text { Russo) }\end{array}$ \\
\hline $\begin{array}{l}\text { The Incredible Hulk - June 13, 2008 } \\
\text { dir. Louis Leterrier) }\end{array}$ & $\begin{array}{l}\text { Thor: The Dark World - November } \\
8,2013 \text { (dir. Alan Taylor) }\end{array}$ & $\begin{array}{l}\text { Doctor Strange - November 4, 2016 } \\
\text { (dir. Scott Derrickson) }\end{array}$ \\
\hline $\begin{array}{l}\text { Iron Man 2 - May 7, 2010 (dir. Jon } \\
\text { Favreau) }\end{array}$ & $\begin{array}{l}\text { Captain America: The Winter Soldier } \\
\text { - April 4, 2014 (dir. Anthony and Joe } \\
\text { Russo) }\end{array}$ & $\begin{array}{l}\text { Guardians of the Galaxy 2 - May 5, } \\
\text { 2017 (dir. James Gunn) }\end{array}$ \\
\hline $\begin{array}{l}\text { Thor - May 6, 2011 (dir. Kenneth } \\
\text { Branagh) }\end{array}$ & $\begin{array}{l}\text { Guardians of the Galaxy - August 1, } \\
\text { 2014 (dir. James Gunn) }\end{array}$ & $\begin{array}{l}\text { Untitled Spider-Man film - July 28, } \\
\text { 2017 }\end{array}$ \\
\hline $\begin{array}{l}\text { Captain America: The First Avenger } \\
- \text { July 22 2011 (dir. Joe Johnston) }\end{array}$ & $\begin{array}{l}\text { Avengers: Age of Ultron - May 1, } \\
\text { 2015 (dir. Joss Whedon) }\end{array}$ & $\begin{array}{l}\text { Thor: Ragnarok - November 3, } \\
\text { 2017 }\end{array}$ \\
\hline $\begin{array}{l}\text { The Avengers - May 4, 2012 (dir. } \\
\text { Joss Whedon) }\end{array}$ & $\begin{array}{l}\text { Ant-Man - July 17, 2015 (dir. Peyton } \\
\text { Reed) }\end{array}$ & $\begin{array}{l}\text { Avengers: Infinity War Part 1 - } \\
\text { May 4, 2018 (dir. Anthony and Joe } \\
\text { Russo) }\end{array}$ \\
\hline & & Black Panther - July 6, 2018 \\
\hline & & $\begin{array}{l}\text { Captain Marvel - November 2, } \\
\text { 2018 }\end{array}$ \\
\hline & $\begin{array}{l}\text { Avengers: Infinity War Part 2 - } \\
\text { May 3, 2019 (dir. Anthony and Joe } \\
\text { Russo) }\end{array}$ \\
\hline
\end{tabular}

The information used from the above table was drawn from Box Office Mojo. Accessed October 16, 2014.

\section{Appendix M}

$\underline{\text { Marvel Cinematic Universe - Television }}$

\begin{tabular}{|l|l|l|l|}
\hline Title & Broadcast Dates & Seasons & Episodes \\
\hline $\begin{array}{l}\text { Marvel's Agents of } \\
\text { S.H.I.E.L.D. }\end{array}$ & $\begin{array}{l}\text { September 24, 2013- } \\
\text { present }\end{array}$ & 2 & 44 \\
\hline Marvel's Agent Carter & January 6, 2015 & 1 & 8 \\
\hline Marvel's Daredevil & April 10, 2015 & 1 & 13 \\
\hline Jessica Jones & - & 1 & 13 \\
\hline Iron Fist & - & 1 & 13 \\
\hline Luke Cage & - & 1 & 13 \\
\hline The Defenders & - & 1 & $4-8$ \\
\hline
\end{tabular}

The information used from the above table was drawn from the Marvel.com Accessed October 16, 2014. 


\section{Appendix N}

$\underline{\text { Marvel Cinematic Universe - Marvel One-Shots }}$

\begin{tabular}{|l|l|l|}
\hline Title & Home Media Reference & U.S. Release Date \\
\hline The Consultant & Thor & September 13, 2011 \\
\hline $\begin{array}{l}\text { A Funny Thing Happened on the } \\
\text { Way to Thor's Hammer }\end{array}$ & $\begin{array}{l}\text { Captain America: The First } \\
\text { Avengers }\end{array}$ & October 25, 2011 \\
\hline Item 47 & The Avengers & September 25, 2012 \\
\hline Agent Carter & Iron Man 3 & September 24, 2013 \\
\hline All Hail the King & Thor: The Dark World & February 25, 2014 \\
\hline
\end{tabular}

The information used from the above table was drawn from Marvel.com

Accessed October 16, 2014.

\section{Appendix O}

Marvel Cinematic Universe - Comic Tie-ins

\begin{tabular}{|c|c|c|c|c|}
\hline Title & Issue & Publication Date & Writers & Arists \\
\hline $\begin{array}{l}\text { Iron Man 2: Public } \\
\text { Identity }\end{array}$ & 3 & April-May 2010 & $\begin{array}{l}\text { Joe Casey and Justin } \\
\text { Therous }\end{array}$ & Barry Kitson and Ron Lim \\
\hline $\begin{array}{l}\text { Iron Man 2: Agents of } \\
\text { S.H.I.E.L.D. }\end{array}$ & 1 & September 2010 & Joe Casey & Tim Green, Felix Ruiz and Mat Camp \\
\hline $\begin{array}{l}\text { Captain America: First } \\
\text { Vengeance }\end{array}$ & 4 & May-June 2011 & Fred Van Lente & Neil Edwards and Luke Ross \\
\hline $\begin{array}{l}\text { The Avengers Prelude: } \\
\text { Fury's Big Week }\end{array}$ & 4 & February-April 2012 & $\begin{array}{l}\text { Chris Yost and Eric } \\
\text { Pearson }\end{array}$ & Luke Ross \\
\hline $\begin{array}{l}\text { The Avengers Prelude: } \\
\text { Black Widow Strikes }\end{array}$ & 3 & May-June 2012 & Fred Van Lente & Neil Edwards \\
\hline Iron Man 3 Prelude & 2 & $\begin{array}{l}\text { January-February } \\
2013\end{array}$ & Christos Gage & Steve Kurth \\
\hline $\begin{array}{l}\text { Thor: The Dark World } \\
\text { Prelude }\end{array}$ & 2 & June-July 2013 & Chris Yost and Craig Kyle & Scott and Ron Lim \\
\hline $\begin{array}{l}\text { Captain America: The } \\
\text { Winter Soldier Infinite } \\
\text { Comic }\end{array}$ & 1 & January 2014 & Peter David & Rock He-Kim \\
\hline $\begin{array}{l}\text { Guardians of the Galaxy } \\
\text { Prequel Infinite Comic }\end{array}$ & 1 & April 2014 & $\begin{array}{l}\text { Dan Abnett and Andy } \\
\text { Lanning }\end{array}$ & Andrea DiVito \\
\hline $\begin{array}{l}\text { Guardians of the Galaxy } \\
\text { Prelude }\end{array}$ & 2 & April-May 2014 & $\begin{array}{l}\text { Dan Abnett and Andy } \\
\text { Lanning }\end{array}$ & Wellinton Alves \\
\hline $\begin{array}{l}\text { Agents of S.H.I.E.L.D.: } \\
\text { The Chase }\end{array}$ & 1 & July 2014 & George Kitson & $\begin{array}{l}\text { Mirko Colak, Neil Edwards ad Mirco } \\
\text { Pierfederici }\end{array}$ \\
\hline Ant-Man Prelude & 2 & February 2015 & Will Corona Pilgrim & Miguel Sepulveda \\
\hline $\begin{array}{l}\text { Avengers: Age of Ultron } \\
\text { Prelude - This Sceptre'd } \\
\text { Isle }\end{array}$ & 1 & February 2015 & Will Corona Pilgrim & Wellinton Alves \\
\hline
\end{tabular}

The information used from the above table was drawn from Marvel Cinematic Universe Wiki - Comics.

Accessed January 18, 2015. 


\section{Appendix P}

$\underline{\text { Marvel Cinematic Universe - Video Games }}$

\begin{tabular}{|l|l|l|}
\hline Title & Video Game Production Company & Release Date \\
\hline Iron Man & Sega & May 2, 2008 \\
\hline The Incredible Hulk & Sega & June 5, 2008 \\
\hline Iron Man 2 & Sega & May 4, 2010 \\
\hline Thor: God of Thunder & Sega & May 3, 2011 \\
\hline Captain America: Super Soldier & Sega & July 19, 2011 \\
\hline Iron Man 3 & Gameloft & April 25, 2013 \\
\hline Thor: The Dark World & Gameloft & October 31, 2013 \\
\hline Captain America: The Winter Soldier & Gameloft & March 27, 2014 \\
\hline $\begin{array}{l}\text { Guardians of the Galaxy: The } \\
\text { Universal Weapon }\end{array}$ & Disney Interactive Media Group & July 17, 2014 \\
\hline
\end{tabular}

The information used from the above table was drawn from Marvel Cinematic Universe Wiki - Video Games. Accessed January 18, 2015. 
Appendix Q

\begin{tabular}{|c|c|c|c|}
\hline Film Property & Studio & Release Date & Director \\
\hline Avengers: Age of Ultron & Marvel Studios & May 1,2015 & Joss Whedon \\
\hline Ant-Man & Marvel Studios & July 17,2015 & Peyton Reed \\
\hline The Fantastic Four & $20^{\text {th }}$ Century Fox & August 7, 2015 & Josh Trank \\
\hline Deadpool & $20^{\text {th }}$ Century Fox & February 12,2016 & Tim Miller \\
\hline $\begin{array}{l}\text { Batman vs. Superman: } \\
\text { Dawn of Justice }\end{array}$ & Warner Bros. & March 25, 2016 & Zack Snyder \\
\hline $\begin{array}{l}\text { Captain America: Civil } \\
\text { War }\end{array}$ & Marvel Studios & May 6, 2016 & Anthony and Joe Russo \\
\hline X-Men: Apocalypse & $20^{\text {th }}$ Century Fox & May 27,2016 & Bryan Singer \\
\hline $\begin{array}{l}\text { Suicide Squad (DC } \\
\text { Comics) }\end{array}$ & Warner Bros. & August 5, 2016 & David Ayer \\
\hline Gambit & $20^{\text {th }}$ Century Fox & October 7, 2016 & \\
\hline Doctor Strange & Marvel Studios & November 4, 2016 & Scott Derrickson \\
\hline $\begin{array}{l}\text { The Sinister Six } \\
\text { (Spiderman) }\end{array}$ & Sony/Columbia & On Indefinite Hiatus & \\
\hline $\begin{array}{l}\text { Untitled The Wolverine } \\
\text { Sequel }\end{array}$ & $20^{\text {th }}$ Century Fox & March 3, 2017 & \\
\hline Guardians of the Galaxy 2 & Marvel Studios & May 5, 2017 & James Gunn \\
\hline Wonder Woman & Warner Bros. & June 23, 2017 & Patty Jenkins \\
\hline $\begin{array}{l}\text { Untitled Fantastic Four } \\
\text { sequel }\end{array}$ & $20^{\text {th }}$ Century Fox & July 14,2017 & \\
\hline Untitled Spider-Man film & Marvel Studios/Sony & July 28,2017 & \\
\hline Thor: Ragnorak & Marvel Studios & November 3, 2017 & \\
\hline Justice League: Part One & Warner Bros. & November 17,2017 & Zack Snyder \\
\hline The Flash & Warner Bros. & March 23, 2018 & \\
\hline $\begin{array}{l}\text { Avengers: Infinity War - } \\
\text { Part One }\end{array}$ & Marvel Studios & May 4, 2018 & Anthony and Joe Russo \\
\hline Black Panther & Marvel Studios & July 6,2018 & \\
\hline Untitled Marvel film & $20^{\text {th }}$ Century Fox & July 13,2018 & \\
\hline Aquaman & Warner Bros. & July 27,2018 & \\
\hline Captain Marvel & Marvel Studios & November 2,2018 & \\
\hline Shazam & Warner Bros. & April 5, 2019 & \\
\hline $\begin{array}{l}\text { Avengers: Infinity War - } \\
\text { Part Two }\end{array}$ & Marvel Studios & May 3, 2019 & Anthony and Joe Russo \\
\hline Justice League: Part Two & Warner Bros. & June 14,1019 & Zack Snyder \\
\hline Cyborg & Warner Bros. & April 3, 2020 & \\
\hline Green Lantern & Warner Bros. & June 19, 2020 & \\
\hline Inhumans & Marvel Studios & July 12,2019 & \\
\hline
\end{tabular}

The information used from the above table was drawn from Gregg Kilday and Borys Kit's The Hollywood Reporter article "29 Superhero Movies Through 2020: a Breakdown of What's Coming," and Kevin Jagernauth's The Playlist article "Channing Tatum's 'Gambit' Sets Fall 2016 Release Date, 'Game Of Thrones' Heads To IMAX And More." Accessed December 26, 2014. 